\title{
MAHOVNA FLORA FITOGEOGRAFSKEGA PODOBMOČJA KARAVANKE (SLOVENIJA)
}

\author{
Andrej MARTINČIČ́
}

\begin{abstract}
Izvleček
V članku avtor podaja rezultate lastnih florističnih raziskav mahovne flore fitogeografskega podobmočja Karavanke (del alpskega fitogeografskega območja), vključuje pa tudi podatke iz literature in neobjavljene podatke iz herbarija LJU. Mahovna flora obsega 453 vrst, od tega 97 vrst jetrenjakov (Marchantiopyta) in 356 vrst listnatih mahov (Bryophyta). Med njimi je 12 vrst novih za Slovenijo (Cephalozia ambigua, Lophozia ascendens, Didymodon asperifolius, Dicranella crispa, Brachytheciastrum olympicum, Schistidium crassipilum, S. dupretii, S. elegantulum subsp. elegantulum, S. lancifolium, S. papillosum, S. robustum, S. trichodon var. trichodon), 94 vrst pa je za fitogeografsko podobmočje omenjeno prvič. V Rdeči seznam ogrožene mahovne flore Slovenije je vključeno 40 vrst. Na evropskem Rdečem seznamu (ECCB 1995) je 11 vrst.

Ključne besede: mahovna flora, jetrenjaki, listnati mahovi, Karavanke, horološka analiza, vrste na Rdečem seznamu.

Abstract

In this paper author gives the results of his own bryological investigations of the phytogeographical subregion Karavanke (part of the Alpine phytogeographical region) as well as the previous reports from literature and unpublished data from LJU. In total 453 species are reported from the investigated subregion, 97 liverworts and 356 mosses. Among them 12 are reported for the first time for Slovenia (Cephalozia ambigua, Lophozia ascendens, Didymodon asperifolius, Dicranella crispa, Brachytheciastrum olympicum, Schistidium crassipilum, S. dupretii, S. elegantulum subsp. elegantulum, S. lancifolium, S. papillosum, S. robustum, S. trichodon var. trichodon), 94 species are reported for the first time for the Karavanke. 40 species are included in national Red List and 11 species in the Red Data Book of European Bryophytes (ECCB 1995).

Key words: bryophyte flora, liverworts, mosses, Karavanke, horological analysis, red-listed species.
\end{abstract}

\section{INTRODUCTION}

Mahovna flora alpskega fitogeografskega območja je bila do najnovejšega časa zelo neenakomerno raziskana. Edine sistematične raziskave do najnovejšega časa je opravil J. Glowacki. Svoje rezultate je objavil kot mahovna flora Pohorja (1908), Julijskih Alp (1910) in Kamniško-Savinjskih Alp (1912). V ta dela je vključil tudi dotedanje razpršene prispevke domačih in tujih botanikov. Kasneje takih raziskav v drugih podobmočjih alpskega fitogeografskega območja ni bilo. Šele v zadnjem času sta bili objavljeni mahovni flori za podobmočje Dravski Kozjak
(Martinčič 2010) in za podobmočje Mežiško-Mislinjska dolina-Strojna (Martinčič 2012). Brez celovitega prikaza mahovne flore je tako ostajalo samo še podobmočje Karavanke. Do leta 1914 so podatke za mahovno floro Karavank prispevali le Deschmann (1862, 1869), Wallnöfer (1888), Breidler (1891), Müllner (1893), Glowacki (1908, 1912) in Paulin (1914). Na podlagi teh podatkov je mahovna flora obsegala 7 vrst jetrenjakov in 109 vrst listnatih mahov. Sledilo je dolgo obdobje brez briofloristične aktivnosti. Šele po letu 1970 so se ponovno pričeli množiti podatki o mahovni flori Karavank, vendar le v objavljenih fitocenoloških popisih (Piskernik \& Martinčič 1970,

${ }^{1}$ Zaloška cesta 78a, 1000 Ljubljana, Slovenija 
Piskernik 1970, 1977, Kutnar, Urbančič \& Čas 2006, Marinček \& Čarni 2007, Juvan 2008, Juvan et al. 2011, Zelnik et al. 2010).

Sistematične raziskave mahovne flore Karavank je avtor opravil v dveh obdobjih. Najprej je v letih 1960-1966 nabiral mahovni material predvsem v višjih predelih Zahodnih Karavank, v letih 2000-2002 pa še v Vzhodnih Karavankah in v nižjih predelih. Del lastnih rezultatov je že upošteval v Seznamu listnatih mahov (Martinčič 2003) in v Seznamu jetrenjakov (Martinčič 2011), ter objavil v več florističnih prispevkih.

\section{METODE}

V letih 1960-1966 ter 2000-2002 je avtor na celotnem območju Karavank nabral obsežen mahovni material. Mahovi so bili nabrani v značilnih in pomembnih habitatih, $v$ gozdovih in na traviščih, na skalovju, na močvirnih mestih, v izvirih, na bregovih vodotokov in na skalah $\mathrm{v}$ njih, na skorji različnih drevesnih vrst, na štorih in razpadlem lesu, najbolj pogosto $\mathrm{v}$ montanskem, subalpinskem in alpinskem pasu, manj pogosto nižje. Vrstno bogato rastišče predstavljajo tudi sekundarni biotopi, zlasti skalnate obcestne brežine.

Mahovni material je shranjen v herbariju Oddelka za biologijo Biotehniške fakultete, Univerze v Ljubljani (LJU). Zaradi popolnosti prikaza so v delu upoštevani tudi podatki drugih avtorjev, objavljeni doslej v literaturi. Manjše število podatkov izvira iz neobjavljenega herbarijskega gradiva $\mathrm{v}$ LJU. V nomenklaturi in taksonomiji smo sledili delu Hill et al. (2006) za listnate mahove (Bryophyta) ter delu Schumacker \& Váňa (2005) za jetrenjake (Marchantiophyta).

Podlaga za opredelitev geoelementov in pripadnosti določenemu geoelementu je delo Düll et al. (1999), vendar v mnogočem modificirano z upoštevanjem del Hill \& Preston (1998) ter Martinčič $(1966,2006)$.

\subsection{KRATKA GEOGRAFSKA IN EKOLOŠKA OZNAKA}

Raziskovani predel je po fitogeografski delitvi Slovenije po Wraberju (1969) vključen v enotno alpsko fitogeografsko območje. Zaradi velikih florističnih in vegetacijskih razlik je bilo alpsko fitogeografsko območje kasneje razdeljeno na štiri podobmočja: Julijske Alpe, Kamniško-Savinjske Alpe, Pohorje in Karavanke (Martinčič \& Sušnik 1969). Slednje se raztezajo v dolžini ok. $100 \mathrm{~km}$ od Peči na tromeji na zahodu, do Slovenjegraške kotline na vzhodu. Fitogeografsko podobmočje Karavanke štejemo sicer kot enoten predel, v geografskem pogledu pa ga v Sloveniji sestavljata dva ločena dela, Zahodne in Vzhodne Karavanke,

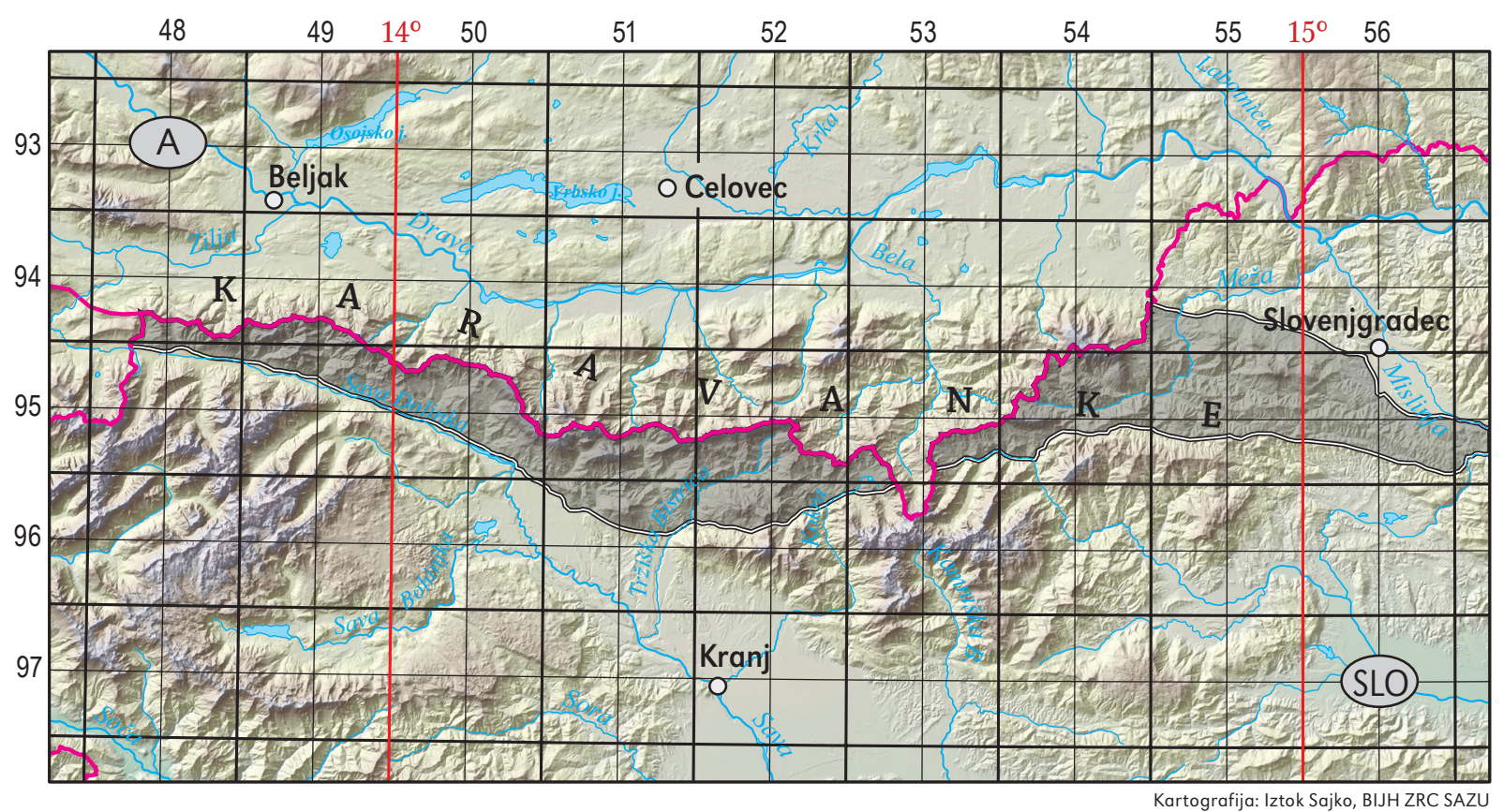

Slika 1: Zemljevid raziskovanega območja - fitogeografsko podobmočje Karavanke.

Figure 1: Map of investigated area - phytogeographical subregion Karavanke. 
ki po Novi regionalizaciji Slovenije (glej Perko \& Orožen-Adamič 1998) predstavljata dve mezoregiji (slika 1). Meje fitogeografskega podobmočja in obeh mezoregij so v največji meri identične. Zahodni del fitogeografskega podobmočja (Zahodne Karavanke) se prične od tromeje na Peči ter poteka do Jezerskega vrha. Na severu poteka meja podobmočja po državni meji; na jugu gre meja po dolini reke Save Dolinke, od Žirovnice dalje po vznožju Karavank do Tržiča, od tu dalje po reki Lomščici čez Javorniški preval, po Reki do Kokre in po njej navzgor, dalje po Jezernici in naprej do Jezerskega vrha. Južna meja vzhodnega dela podobmočja (Vzhodne Karavanke) se prične na Pavličevem sedlu, teče po rečici Jezera in dalje po Savinji do Solčave, kjer se nadaljuje preko Spodnjega Slemena po reki Bistri in Vrtačnikovem potoku. Naprej poteka po severnem vznožju Smrekovca, prek Slemena po Velunji in Črnem potoku do Pake ter preko Zgornjega Doliča do Mislinje na skrajnem vzhodu. Severna meja podobmočja (Vzhodnih Karavank) poteka od Mislinje preko Mislinjske Dobrave, po Jenini in Suhodolnici mimo Starega trga, dalje preko Podgore, Podkraja, mimo Leš in nad Mežico doseže avstrijsko mejo.

Kamninska podoba Karavank je izredno pestra (Perko \& Orožen-Adamič 1998). Po eni strani jih sestavljajo karbonatne kamnine, apnenci različne geološke starosti in dolomiti, ki gradijo zlasti v Zahodnih Karavankah večji del površja, posebno v višjih predelih. Tudi v Vzhodnih Karavankah gradijo karbonatne kamnine zlasti višje predele, np. Peco, Olševo, Uršljo goro. Silikatne kamnine zavzemajo manjše površine, razen $\mathrm{v}$ Vzhodnih Karavankah, pogosto se pojavljajo mozaično, sestavljajo pa jih zlasti peščenjaki, skrilavi glinovci, tufi, globočnine in gnajsi. Podobno pestra je tudi pedološka in vegetacijska podoba.

Naravna gozdna vegetacija se pričenja s pasom bukve, saj pas nižinskih gozdov belega gabra in hrastov zaradi nadmorske višine ni razvit. Velik del zahodnih Karavank v montanskem pasu porašča conalna združba Anemono trifoliae-Fagetum, ki sega do nadmorske višine $1300 \mathrm{~m}$ in višje, marsikje celo zaključuje gozdno vegetacijo. Vendar ne sega v vzhodne Karavanke. Na nekarbonatnih kamninah in na zakisanih tleh uspeva aconalna združba Luzulo albidae-Fagetum, ki v vzhodnih Karavankah, kjer prevladujejo kisle kamnine, pokriva največje površine, ponekod $\mathrm{z}$ močno primesjo jelke. Pas smreke se pričenja na nadmorski višini 1250/1300 m. Conalna združba Adenostylo glabrae-Piceetum ne tvori sklenjenega pasu, uspeva pa na nadmorski višini 1300/14001600 m. V vzhodnih Karavankah ima conalni značaj tudi združba Luzulo sylvaticae-Piceetum. $\mathrm{Na}$ manjših površinah so razvite še aconalne in drugotne smrekove združbe, npr. Aposerido-Piceetum. Subalpinski pas, ki se prične nad gozdno mejo, navadno nad 1600-1700 m, je dosežen sicer marsikje, vendar so sklenjeni sestoji rušja, značilne rastline tega pasu, razviti le na manjših površinah. Predstavljajo conalno združbo Rhodothamno-Pinetum mugo. Nad gozdno mejo oz. nad pasom rušja se prične visokogorska vegetacija, ki jo tvorijo številne združbe travišč, skalnih razpok, melišč, visokogorskih resav ter snežnih tal.

\subsection{LoKalitete}

Seznam lokalitet obsega tiste, kjer je nabiral mahovni material avtor prispevka ter lokalitete drugih avtorjev, navedene $\mathrm{v}$ literaturi in $\mathrm{v}$ herbariju LJU. Slednje so izpisane ležeče, dodan pa je tudi vir. Lokalitete so razporejene po legi v kvadrantih mreže srednjeevropskega florističnega kartiranja, zato se nekatere pojavljajo dvakrat. Dodana je še lega v UTM $(33 T-10 \times 10 \mathrm{~km})$ mreži.

9448/3 - Peč, pri planinskem domu Tromeja, $1200 \mathrm{~m}$, 10. 7. 2001 (VM05).

- nad Ratečami, 1000 m, 10. 7. 2001 (VM05).

- na Trebižah nad Ratečami, 1100 m, 10. 7. 2001 (VM05).

9448/4 - Petelinjek nad Korenskim sedlom, 1425 m, 2003, leg. M. Zupančič (VM05).

- Medvedjek nad Podkorenom, 1000 m, 2001 (VM05).

Bavha nad Podkorenom. Piskernik 1977 (VM05).

9455/4 - Ravnjakov vrh nad Prevaljami, 860 m. Grom LfU 1958 (VM95).

Uršlja gora, vznožje. Wallnöfer 1888 (VM95).

9456/3 - Vrhe pri Slovenj Gradcu, 530 m. Grom LfU 1961 (WM05).

9548/2 - nad Podkorenom, 950 m, 10. 7. 2001 (VM05).

Podkoren, 850 m. Piskernik 1977 (VM04).

9549/1 - med Gozd Martuljkom in Belco, 700 m, 10. 7. 2001 (VM14).

- Srednji vrh nad Gozd Martuljkom, 950 m, 10. 7. 2001 (VM14).

- nad Gozd Martuljkom, 800 m, 1000 m, 10. 7. 2001 (VM14).

9549/2 - nad Dovjem, 850, obcestna brežina, 18. 7. 2001 (VM24). 
- Belca pri Dovjem, 1971 (VM14).

- Dovška Baba, 1800 m, 26. 8. 1960 (VM24).

Kališe nad Dovjem. Piskernik 1977 (VM24).

9550/1 - Črni vrh nad Jesenicami, 1400 m, 1957,

24. 8. 1960 (VM24).

- Krvavka, 1750 m, 1000 m, 25. 8. 1960 (VM24).

- Sv. Križ pri Planini pod Golico, 1000 m, 25. 8. 1960 (VM24).

- Velika Golica, 1800 m, 1400 m, 25. 8. 1965 (VM24).

- Hruška planina pod Rožco, 1250 m, 26. 8. 1961 (VM24).

- Hruški vrh, 1700 m, 26. 8. 1960 (VM24).

- Klek, 1600 m, 25. 8. 1960 (VM24). Španov vrh, 1350 m. Piskernik 1977 (VM24). Crni orh nad Jesenicami, $1350 \mathrm{~m}$. Piskernik 1977 (VM24).

9550/2 - Medji dol, 1000 m, 27. 8. 1961 (VM34).

- Struška Kočna, 1600 m, 27. 8. 1961 (VM34).

- Korenščica, 1500 m, 27. 8. 1961 (VM34).

- Javorniški Rovt, 1100 m, 27. 8. 1961 (VM34).

- planina Pusti Rovt pod Korenščico, 1500 m, 27. 8. 1961 (VM34).

9550/4 - Debelo brdo pod Belščico, 1200 m, 28. 8. 1961 (VM34).

- Potoška planina pod Belščico, 1300 m, 28. 8. 1961 (VM34).

- pri Valvazorjevem domu pod Stolom, 1200 m, 30. 8. 1961 (VM34).

- med Javornikom (Jesenice) in Javorniškim Rovtom, 800 m, 27. 8. 1961 (VM34).

- Vajnež, 2100 m, 29. 8. 1961 (VM34).

- Gozdašnica nad dolino Završnico, 800 m, 13. 8. 2001 (VM34).

Belšcica. Paulin 1914 (VM34).

Koroška Bela. Plemelj V. LfU (VM34).

9551/3 - dolina Završnica, 1000 m, 30. 6. 1966 (VM34).

- dolina Završnica, Žingarica, 800 m, 13. 8. 2001 (VM34).

- Stol, 2000 m, 29. 8. 1961 (VM34).

- nad planino Vrtačo, 1400 m, 1957 (VM34).

- Begunjščica, vrh, 2000 m, 30. 6. 1966 (VM44).

- Begunjščica, nad Poljško planino, 1500 m, 29. 6. 1966 (VM44).

Zelenica. Plemelj V. LfU 1873; Müllner 1893 (VM44).

9551/4 - Ljubelj, 1000 m, 5. 9. 2001 (VM44).

- Ljubelj: Sv. Ana, 900 m, 26. 6. 1966 (VM44).

- Vranček pod Ljubeljem, 850 m, 5. 9. 2001 (VM44).

- Lajb pod Ljubeljem, 750 m, 5. 9. 2001 (VM44).

- Podljubelj, 700 m, 1971, 1984 (VM43).
Felendol, proti Čizovcu, 1400 m. Marinček \& Čarni 2010 (VM53).

Košuta: Kofce, 1010 m, 1200 m. Piskernik 1977 (VM44).

Košuta: planina Korošica. Wallnöfer 1888 (VM44).

9552/3 - Jelendol, pod Penatco, 900 m, 5. 9. 2001

(VM54).

- Medvodje pod Penatco 950 m, 5. 9. 2001 (VM54).

9552/4 - Spodnje Jezersko: Tisovec, 850 m, 16. 9. 2002 (VM63).

9553/3 - Zgornje Jezersko: pod Roblekom, 1000 m, 16. 9. 2002 (VM64).

9553/4 - pod Pavličevim sedlom, pri kmetiji Covnik, 1200 m, 23. 8. 2001 (VM74).

9554/1 - Olševa, sev. pobočje, 1300 m, 1969, 19. 9. 2001 (VM74).

- Olševa: barje Zadnji travnik, 1340 m, 19. 9. 2001 (VM74).

- Olševa, Zadnji travnik, 1400 m, 19. 9. 2001 (VM74).

- Koprivna, pri kmetiji Kumar, 1300 m, 19. 9. 2001 (VM74).

- dolina Koprivna, 950 m, 19. 9. 2001 (VM84).

Olševa, Zadnji travnik, 1300 m. Piskernik 1977 (VM74).

Olševa, 1400 m. Kutnar, Urbančič \& Čas 2006 (VM74).

Kopriona, $500 \mathrm{~m}, 1000 \mathrm{~m}$. Piskernik 1977 (VM74).

Mozganov vrh. Piskernik 1977 (VM74).

9554/2 - Mala Peca, 1400 m, 20. 9. 2001 (VM84).

- dolina Topla, nad Fajmutom, 1100 m, 1400 m, 20. 9. 2001 (VM84).

- dolina Topla, pod Florinom, 850 m, 20. 9. 2001 (VM84).

- dolina Topla, pod Burjakovim hribom, $700 \mathrm{~m}, 20.9 .2001$ (VM84).

- Janškov graben nad dolino reke Meže, 850 m, 1996 (VM84).

Javorje pod Malo Peco, 1320 m. Kutnar, Urbančič \&̊ Čas 2006 (VM84).

Najbrževo pod Malo Peco, 1400 m. Kutnar, Urbancič \& Čas 2006 (VM84).

Čofatijev vrh, 1400 m. Piskernik 1977 (VM84).

dolina Topla, 680 m. Piskernik 1977 (VM84).

Koprivna: Sv. Fakob. Glowacki 1908 (VM84).

9554/3 - Olševa, juž. pobočje, 800 m, 11. 9. 1973 (VM74).

- Olševa, Potočka zijalka, vhod, 1700 m, 3. 10. 2000 (VM74).

- Olševa, pod Potočko zijalko, 1600 m, 3. 10. 2002 (VM74). 
- Sv. Duh pod Olševo, pri Potočniku, 1200 m, 3. 10. 2002 (VM74).

- Strevčev vrh pri Olševi, nad Rogarjem, 1400 m, 1500 m, 3. 10. 2002 (VM74).

Olševa, 1650 m. Piskernik 1977 (VM74).

nad Solčavo, levi breg Savinje. Grom LfU 1970 (VM74).

Olševa. Breidler 1891 (VM74).

9554/4 - dolina reke Bistre, Knezove peči, $1100 \mathrm{~m}$. Grom LfU 1960 (VM84).

9555/1 - pri Črni na Koroškem, proti Javorju, $650 \mathrm{~m}, 21.9 .2001$ (VM94).

- dolina reke Bistre, 650 m, 21. 9. 2001 (VM84). Ludranski vrh, 1020 m. Grom LfU 1960 (VM94). Ludranski vrh: Podgora. Grom LfU 1960 (VM94). Jazbina pri Žerjavu, $700 \mathrm{~m}, 880 \mathrm{~m}$. Piskernik 1977 (VM94).

Žerjav, 550 m. Piskernik 1977 (VM94).

Črna na Koroškem, breg reke Bistre, $620 \mathrm{~m}$. Fuvan 2008 (VM84).

9555/2 - Uršlja gora, vzh. pobočje, 1100 m, 18. 9. 2001 (VM94).

- Uršlja gora, 1500 m, 1600 m, 1968, 18. 9. 2001 (VM94).

- Uršlja gora: Kozakinovo, 1968 (VM94).

- Plešivški mlin pod Uršljo goro, 900 m, 18. 9. 2001 (VM94).

- Uršlja gora, pri kmetiji Plešivec, 1000 m, 18. 9. 2001 (VM94.

Uršlja gora: Črni vrh, 1010 m. Grom LfU 1958 (VM94).

Uršlja gora, 1000 m, 1400 m. Piskernik 1977 (VM94).

Molakov vrh nad Zgornjim Razborjem, $950 \mathrm{~m}$. Piskernik 1977 (VM94).

Plešivec, 1100 m. Piskernik 1977 (VM94).

Uršlja gora, Plešivec, juž. pobočje, $890 \mathrm{~m}$. Grom LfU 1958 (VM94).

9555/4 - Bačovski vrh, $1000 \mathrm{~m}$, 19. 9. 2001 (VM94).

9556/1 - Zgornji Razbor, 700 m, 18. 9. 2001 (WM04).

- Spodnji Razbor pri Mislinjski Dobravi, 500 m, 18. 9. 2001 (WM04).

- Podgorje pri Slovenj Gradcu, 450 m, 18. 9. 2001 (WM04).

Blatnica, vzh. od Uršlje gore, 820-970 m. Piskernik 1977 (WM04).

Kozarnica, vzh. od Uršlje gore, 1000 m. Piskernik 1977 (WM04).

9556/4 - Završe pri Mislinji. Piskernik 1977 (WM14). 9651/1 - Draga pri Begunjah na Gorenjskem, $690 \mathrm{~m}, 1980$; 13. 8. 2001 (VM43).
- Smokuč pri Begunjah na Gorenjskem, 540 m, 13. 8. 2001 (VM33).

Begunje na Gorenjskem. Müllner 1893 (VM33).

Sv. Peter nad Begunjami na Gorenjskem, $700 \mathrm{~m}$. Piskernik 1977 (VM33).

9651/2 - Čadovlje pri Tržiču, 600 m, 5. 7. 2001 (VM43).

- Stolec nad Tržičem, 560 m, 5. 9. 2001 (VM43).

Beli potok pri Podljubelju. Glowacki 1912 (VM43).

nad Tržičem, 550 m. Dolšak LfU 1920 (VM43).

9652/1 - Javorniško sedlo (za Storžičem), 1400 m,

24. 8. 1962 (VM53).

- Dolžanova soteska, pri vasi Dolina, $750 \mathrm{~m}$, 5. 9. 2001 (VM43).

Jelendol, $1350 \mathrm{~m}$. Marinček \&ै Čarni 2007 (VM54).

dolina Tržiške Bistrice. Glowacki 1912 (VM43).

9652/2 - pod Javorniškim sedlom (za Storžičem),

800 m, 24. 8. 1962 (VM53).

Stegounik. Piskernik 1977 (VM53).

\section{REZULTATI IN RAZPRAVA}

\subsection{FlORISTIČNI REZULTATI}

Mahovna flora fitogeografskega podobmočja Karavanke obsega 453 vrst, od tega 356 vrst listnatih mahov (Bryophyta) ter 97 vrst jetrenjakov (Marchantiophyta). Pri listnatih mahovih predstavlja to število 56\% doslej ugotovljenih vrst v Sloveniji. Število ugotovljenih vrst jetrenjakov pa predstavlja 58\% trenutno v Sloveniji znanih vrst (Martinčič 2011). Za fitogeografsko podobmočje Karavanke so prvič zabeležene 3 vrste jetrenjakov ter 89 vrst in 14 varietet listnatih mahov. Nadalje, 13 vrst jetrenjakov ter 21 vrst listnatih mahov je sicer že bilo vpoštevanih v obeh Seznamih (Martinčič 2003, Martinčič 2011a), vendar so šele na tem mestu navedene njihove lokacije. Nove vrste za Slovenijo so Cephalozia ambigua, Lophozia ascendens, Dicranella crispa, Didymodon asperifolius, Brachytheciastrum olympicum, Schistidium crassipilum, $S . d u$ pretii, S. elegantulum subsp. elegantulum, S. lancifolium, $S$. papillosum, $S$. robustum in $S$. trichodon var. trichodon. Floristično pomembne vrste, ki imajo v Sloveniji največ 5 nahajališč in s tem izpolnjujejo po IUCN (2001) kriterijih najpomembnejši pogoj za uvrstitev v kategorijo »prizadete vrste « (EN) so še Anthelia juratzkana, Asterella gracilis, Athalamia hyalina, Blepharostoma trichophyllum subsp. brevirete, Cephalozia pleniceps, Diplophyllum taxifolium, Jungermannia polaris, Lophozia badensis, 
Lophozia elongata, Peltolepis quadrata, Tritomaria exsectiformis subsp. exsectiformis med jetrenjaki ter Cynodontium fallax, Encalypta affinis, Eurhynchium pulchellum var. diversifolium, Grimmia elatior, Kiaeria starkei, Racomitrium affine, Racomitrium microcarpon, Sciuro-hypnum glaciale in Tortula schimperi med listnatimi mahovi. Dobra polovica naštetih vrst spada k arktično-alpinskemu oz. subarktično-subalpinskemu geoelementu, preostali del pa predvsem k borealno-montanskemu.

Cephalozia ambigua: subarktično-alpinski geoelement, v Evropi razširjen v Skandinaviji ter $\mathrm{v}$ gorstvih od Pirenejev, preko alpskih predelov dalje proti vzhodu do Rusije. V jugovzhodni Evropi je vrsta doslej ugotovljena v Bolgariji in Romunijii (Sabovljević \& Natcheva 2006) ter v Makedoniji (Martinčič 2009). Obe nahajališči v Karavankah sta v subalpinskem pasu. V letu 2003 pa smo jo našli tudi v Julijskih Alpah, na Mangartu-Rdeča skala, $2100 \mathrm{~m}$, v alpinskem pasu.

Lophozia ascendens: borealno-montanska vrsta, uspeva predvsem na razpadlem lesu, v gorskih iglastih gozdovih, $\mathrm{v}$ okolju z visoko zračno vlago. V Evropi uspeva v Skandinaviji ter v evropskih gorstvih, na Balkanskem polotoku pa je znana le iz Bolgarije in Srbije (Papp \& Erzberger 2005, Ros et al. 2007). Nahajališče v Sloveniji se tako navezuje na širši srednjeevropski del areala. Na podlagi tega areala lahko sklepamo, da je v Sloveniji bolj razširjena kot je to razvidno iz trenutnega stanja, saj je zaradi majhnosti najbrž marsikje prezrta. Za Slovenijo smo jo sicer že navedli (Martinčič 2011a), vendar brez točnega nahajališča.

Brachytheciastrum olympicum: subatlantskosubmediteranska vrsta, razširjena v širšem mediteranskem prostoru. Za Slovenijo jo navajata Pavletić in Grom (1958) za Sežano, v submediteranskem fitogeografskem območju in Grom (1963, 1969) brez natančne lokacije, za Trnovski gozd, v dinarskem fitogeografskem območju. Herbarijski material z obeh nahajališč je shranjen v LJU, vendar je brez sporogonov. Ker je gladka seta zelo pomemben razlikovalni znak, po katerem $B$. olympicum takoj ločimo od $B$. velutinum, sta obe navedbi dvomljivi (Martinčič 2003).

Dicranella crispa: borealno-montanska vrsta, uspeva na vlažnejši, zlasti peščeni podlagi, na bregovih voda, pogosto na sekundarnem rastišču, na obcestnih brežinah. V Evropi je razširjena $v$ Skandinaviji ter v širokem pasu od Śpanije do Rusije, povsod raztreseno do redko. V jugovzhodni Evropi je znana le iz Romunije (Sabovljević et al. 2008). Nahajališča v Sloveniji so tako na južnem obrobju sklenjenega evropskega areala. Za Slovenijo sicer navaja vrsto že Reichardt (1860) za okolico Dobrne, vendar je podatek zaradi časovne oddaljenosti močno dvomljiv. Nahajališče Olševa: Zadnji travnik, $1400 \mathrm{~m}$, iz leta 2001 je torej prvi zanesljivi podatek o uspevanju te vrste v Sloveniji. V letu 2011 smo našli vrsto še na Strojni (Libeliška gora, Ridlov graben ter dolina Šentanelske reke, pri Zgonikovem mlinu); na obeh nahajališčih uspeva na obcestni brežini. Kljub točni določitvi, sta bila oba podatka v delu Martinčič (2012) napačno objavljena pri vrsti Dicranella schreberiana.

Didymodon asperifolius: arktično-alpinski geoelement, ki v Evropi južno od Skandinavije navadno uspeva v subalpinskem in alpinskem pasu. Pavletić (1955) navaja vrsto za Slovenijo na podlagi herbarija J. Šaferja. Vendar tega materiala v tem herbariju ni, ne omenja pa ga niti Głowacki (1913), ki je objavil vse herbarijske lokalitete Šaferja. Prvo zanesljivo nahajališče v Sloveniji je Lajb pod Ljubeljem, ob potoku Mošenik, na nadmorski višini $800 \mathrm{~m}$. Istočasno pa je tudi najbolj južno nahajališče v alpskem delu areala, saj vrsta zaenkrat ni poznana z Balkanskega polotoka (Ros et al. 2013). Nizka nadmorska višina in breg vodotoka navajata na sklep, da je rastišče obravnavane vrste sekundarno, da je prišlo do naplavljenja iz višjih predelov.

\subsection{SEZNAM TAKSONOV}

Kratice za oznako stopnje ogroženosti, uporabljene v Seznamu taksonov:

EN - ogrožena vrsta (Endangered); VU ranljiva vrsta (Vulnerable); NT - potencialno ogrožena vrsta (Near threatened); DD - premalo znana vrsta, stari podatki, pred letom 1950 (Datadeficient); DD-n - premalo znana vrsta, novi podatki (Data-deficient new).

$\mathrm{Z}$ * so označene nove vrste za fitogeografsko podobmočje Karavanke (with * are marked new species for subregion Karavanke).

\section{Marchantiophyta - jetrenjaki}

Anastrophyllum minutum (Schreb.) R.M. - bor-mont: Korenščica, 1700 m (Martinčič 2010); Belščica (Paulin LJU 1900); dolina Topla, pod Florinom, 850 m; Javorniško sedlo (za Storžičem), 1400 m; Javornik pri Jesenicah (Deschmann 1869). 
var. weberi (Mart.) Kartt. - bor-mont: Korenščica, 1700 m (Martinčič 2010); pod Belščico (Paulin LJU 1900); pod Pavličevim sedlom, pri kmetiji Covnik, 1200 m; Čadovlje pri Tržiču, $600 \mathrm{~m}$.

Aneura pinguis (L.) Dumort. - subbor: Kot pri Prevaljah (Zelnik et al. 2010); pod Pavličevim sedlom, blizu kmetije Covnik, 1150 m (Martinčič 2010); Sele, Blatnik (Zelnik et al. 2010).

VU-Anthelia juratzkana (Limpr.) Trevis. - arkt-alp: Stol, $2000 \mathrm{~m}$.

Apometzgeria pubescens (Schrank) Kuwah. - bor-mont: Belščica (Paulin LJU 1900); pri Valvazorjevem domu, pod Stolom, $1200 \mathrm{~m}$; Debelo brdo pod Belščico, 1200 m; Begunjščica, 1000 m (Martinčič 2003); Ljubelj, 1000 m; Javorje pod Malo Peco (Kutnar et al. 2006, det. Martinčič); Olševa, pod Potočko zijalko, 1600 m; Podljubelj, 1000 m (Grom LJU 1963); Javorniško sedlo (za Storžičem), $1400 \mathrm{~m}$.

VU-Asterella gracilis (F. Web.) Underw. - subarkt-subalp: Olševa, Potočka zijalka, vhod, $1700 \mathrm{~m}$.

VU-Athalamia hyalina (Somerf.) S. Hatt. - subarkt-subalp: Olševa, Potočka zijalka, vhod, 1700 m (Martinčič 2010).

VU-Barbilophozia attenuata (Mart.) Loeske bor-mont: Javorniški Rovt, 1100 m (Martinčič 2010).

Barbilophozia barbata (Schmidel ex Schreb.) Loeske - subbor: dolina Topla, 800 m (Martinčič 2010).

*Barbilophozia floerkei (Web. et Mohr) Loeske bor-mont: Velika Golica, vrh, $1800 \mathrm{~m}$.

Barbilophozia hatcheri (A. Evans) Loeske - bor-mont: Struška Kočna, 1600 m.

Barbilophozia lycopodioides (Wallr.) Loeske bor-mont: Struška Kočna, 1600 m (Martinčič 2010).

Bazzania trilobata (L.) Gray - subbor: Uršlja gora: Ravnjakov vrh, 910 m (Grom LJU 1958, det. Martinčič); med Hruško planino in Sv. Križem pri Planini pod Golico, 1100 m; Javorniški Rovt, 1100 m; Debelo brdo pod Belščico, $1200 \mathrm{~m}$; pri Valvazorjevem domu, pod Stolom, 1200 m; Jelendol, pod Košuto (Grom LJU 1958); Zgornje Jezersko: pod Roblekom, $1000 \mathrm{~m}$; pod Pavličevim sedlom (Grom LJU 1970); pod Pavličevim sedlom, pri kmetiji Covnik, $1200 \mathrm{~m}$; dolina Koprivna, $950 \mathrm{~m}$; dolina Topla, pod Fajmutom, 1400 m; Olševa, pod Potočko zijalko, $1600 \mathrm{~m}$; pod Olševo (Grom LJU 1970); pri Solčavi, levi breg Savinje (Grom LJU 1970); pri Črni na Koroškem, proti Javorju, 650 m; Bačovski vrh, 1000 m; Zgornji Razbor,
700 m; Podstoržič, vrh Orlovec (Grom LJU 1960).

Blepharostoma trichophyllum (L.) Dumort. subbor: nad Gozd Martuljkom, 800 m; Krvavka, $1500 \mathrm{~m}$ (Martinčič 2003); med Hruško planino in Sv. Križem pri Planini pod Golico, 1100 m; Črni vrh nad Jesenicami, 1400 m; Klek, 1600 m; Struška Kočna, 1600 m; Javorniški Rovt, 1100 m; Medji dol, 1000 m; Vajnež, $2100 \mathrm{~m}$; Debelo brdo pod Belščico, $1200 \mathrm{~m}$; med Javornikom (Jesenice) in Javorniškim Rovtom; Stol, 2000 m; Begunjščica, 1300 m, $2000 \mathrm{~m}$; dolina Završnica, pod Begunjščico, $1000 \mathrm{~m}$; pod Ljubeljem, $950 \mathrm{~m}$; Jelendol, pod Penatco, 900 m; Jelendol (Grom LJU 1959, det. Martinčič); Zgornje Jezersko: pod Roblekom, $1000 \mathrm{~m}$; pod Pavličevim sedlom, pri kmetiji Covnik, 1200 m; Olševa, sev. pobočje, 1300 m; dolina Koprivna, 1200 m; Olševa 1400 m (Kutnar et al. 2006, det. Martinčič); Mozganov vrh, 590 m (Piskernik 1977, det. Martinčič); dolina Topla, pri Florinu, $900 \mathrm{~m}$; dolina Topla, nad Fajmutom, 1400 m; Janškov graben, nad dolino reke Meže, 850 m; Strevčev vrh pri Olševi, pod Rogarjem, 1400 m; Olševa, pod Potočko zijalko, 1600 m; Uršlja gora, 1600 m, Bačovski vrh, 1000 m; Zgornji Razbor pri Slovenj Gradcu, 700 m; Čadovlje pri Tržiču, 600 m; Javornik pri Jesenicah (Deschmann 1869).

subsp. brevirete (Bryhn \& Kaal) R. M. Schust. arkt-alp: Vajnež, $2100 \mathrm{~m}$; Stol, $2000 \mathrm{~m}$.

Calypogeia azurea Stotler et Crotz - subbor: Črni vrh nad Jesenicami, 1400 m; Velika Golica, 1400 m; Javorniški Rovt, 1100 m; Debelo Brdo pod Belščico, $1200 \mathrm{~m}$; pri Valvazorjevem domu pod Stolom, 1200 m; Begunjščica, nad Poljško planino, $1500 \mathrm{~m}$; dolina Završnica, pod Begunjščico, 1000 m (Martinčič 2010); Zgornje Jezersko: pod Roblekom, 1000 m; pod Pavličevim sedlom, pri kmetiji Covnik, $1200 \mathrm{~m}$; pod Pavličevim sedlom, 1250 m (Grom LJU 1970, det. Martinčič); Olševa: barje Zadnji travnik, 1340 m; Olševa, sev. pobočje, 1300 m (Martinčič 2010); dolina Topla, nad Fajmutom, 1400 m; dolina Topla, pri Florinu, 900 m; Strevčev vrh pri Olševi, 1500 m; pri Črni na Koroškem, proti Javorju, 650 m; Bačovski vrh, 1000 m; Zgornji Razbor, 700 m; Javorniško sedlo (za Storžičem), $1300 \mathrm{~m}$.

Calypogeia fissa (L.) Raddi - temp: nad Gozd Martuljkom, 800 m; dolina Topla, 750 m (Martinčič 2010).

Calypogeia integristipula Steph. - bor-temp: Ja- 
vorniški Rovt, 1100 m; Potoška planina pod Belščico, 1200 m (Martinčič 2010); Debelo brdo pod Belščico, 1200 m; Vranček pod Ljubeljem, 850 m; Zgornje Jezersko: pod Roblekom, $1000 \mathrm{~m}$; pod Pavličevim sedlom, pri kmetiji Covnik, 1200 m; Olševa, sev. pobočje, 1300 m; Janškov vrh nad dolino Koprivno (Grom LJU 1970); Olševa: barje Zadnji travnik, 1340 m; dolina Topla, nad Fajmutom, 1400 m; dolina Topla, pri Florinu, 900 m (Martinčič 2010); Strevčev vrh pri Olševi, pod Rogarjem, 1400 m; pri Črni na Koroškem, proti Javorju, 650 m; Bačovski vrh, 1000 m; Zgornji Razbor, 700 m.

Calypogeia muelleriana (Schiffn.) Müll. Frib. subbor: Velika Golica, $1400 \mathrm{~m}$; pri Valvazorjevem domu pod Stolom, 1200 m; Olševa, sev. pobočje, $1300 \mathrm{~m}$; Olševa: barje Zadnji travnik, 1340 m; Olševa, sev. pobočje, 1400 m (Kutnar et al. 2006, det. Martinčič); dolina Topla, pod Florinom, $850 \mathrm{~m}$; pod Olševo, 1290 m (Grom LJU 1970, det. Martinčič); Sleme nad dolino Koprivno (Grom LJU 1964); Strevčev vrh pri Olševi, $1500 \mathrm{~m}$; dolina reke Bistre, $650 \mathrm{~m}$.

Calypogeia neesiana (C. Massal. et Carestia) Müll. Frib. - bor-mont: Javorniški Rovt, 1100 m (Martinčič 2010); Strevčev vrh pri Olševi, 1500 m (Martinčič 2010); Ludranski vrh: Podgora (Grom LJU 1960); Zgornje Jezersko: pod Roblekom, 1000 m; Zgornji Razbor, 700 m.

Calypogeia suecica (Arnell et J. Perss.) Müll. Frib. - bor-mont: Potoška planina pod Belščico, 1300 m (Martinčič 2010).

*VU-Cephalozia ambigua C. Massal. - subarkt-subalp: Struška Kočna, 1600 m; Uršlja gora, $1500 \mathrm{~m}$.

Cephalozia bicuspidata (L.) Dumort. - bor-temp: Klek, 1600 m; Javorniški Rovt, 1100 m (Martinčič 2010); pod Pavličevim sedlom, pri kmetiji Covnik, 1200 m; Koprivna, 1200 m; Olševa, sev. pobočje, $1300 \mathrm{~m}$; dolina Topla, pri Florinu, 900 m (Martinčič 2010); pri Črni na Koroškem, proti Javorju, $650 \mathrm{~m}$; dolina reke Bistre, $650 \mathrm{~m}$.

Cephalozia catenulata (Hueben.) Lindb. - bor-temp: med Javornikom in Javorniškim Rovtom, $600 \mathrm{~m}$; pod Ljubeljem, $950 \mathrm{~m}$ (Martinčič 2010); pri Črni na Koroškem, proti Javorju, 650 m (Martinčič 2010).

Cephalozia leucantha Spruce - bor-mont: Vajnež, $2100 \mathrm{~m}$; Javorniško sedlo (za Storžičem), 1400 m (Martinčič 2010).

Cephalozia lunulifolia (Dumort.) Dumort. bor-mont: planina Pusti rovt pod Korenščico, 1500 m (Martinčič 2010); dolina Topla, pri Flo- rinu, 900 m; Strevčev vrh pri Olševi, nad Rogarjem, 1400 m; Olševa, pod Potočko zijalko, 1600 m (Martinčič 2010).

NT-Cephalozia pleniceps (Austin) Lindb. - bor-mont: Olševa, barje Zadnji travnik, $1340 \mathrm{~m}$ (Martinčič 2010).

Chiloscyphus coadunatus (Sw.) J. J. Engel et R. M. Schust. - temp: Peč, pri planinskem domu Tromeja, 1200 m; Hruška planina pod Rožco, 1200 m (Martinčič 2010); Gozdašnica, nad dolino Završnico, 800 m; Zgornji Razbor, 700 m (Martinčič 2010).

var. rivularis Loeske: Hruška planina pod Rožco, 700 m (Martinčič 2010); Medji dol, 1000 m; dolina Završnica, $800 \mathrm{~m}$; Zg. Jezersko: pod Roblekom, 1000 m; dolina Topla, pri Florinu (Martinčič 2010).

Chiloscyphus minor (Nees) J. J. Engel et R. M. Schust. - temp-subkont: Peč, pri planinskem domu Tromeja, 1200 m (Martinčič 2010); pod Pavličevim sedlom, pri kmetiji Covnik, 1200 m; Olševa, pod Potočko zijalko, 1600 m (Martinčič 2010); Čadovlje pri Tržiču, 600 m; Javorniško sedlo (za Storžičem), $1400 \mathrm{~m}$.

Chiloscyphus pallescens (Ehrh. ex Hoffm.) Dumort. - subbor: Črni vrh nad Jesenicami, 1400 m; med Hruško planino in Sv. Križem pri Planini pod Golico, 1000 m; Krvavka, 1000 m; Javorniški Rovt, 1100 m; Jelendol, pod Penatco, $900 \mathrm{~m}$; Spodnje Jezersko: Tisovec, $850 \mathrm{~m}$; Zgornje Jezersko: pod Roblekom, 1000 m; Koprivna, $1300 \mathrm{~m}$; dolina Topla, $750 \mathrm{~m}$; Strevčev vrh pri Olševi, nad Rogarjem, 1400 m; Zgornji Razbor, 700 m (Martinčič 2010); Čadovlje pri Tržiču, 600 m (Martinčič 2010).

Chiloscyphus polyanthos (L.) Corda - subbor: Gozdašnica nad dolino Završnico, $800 \mathrm{~m}$ (Martinčič 2010); Jelendol, pod Penatco, 900 m; Spodnje Jezersko: Tisovec, $850 \mathrm{~m}$; dolina Topla, $750 \mathrm{~m}$; dolina Koprivna, ob reki Koprivni, 900 m; Strevčev vrh pri Olševi, nad Rogarjem, 1400 m (Martinčič 2010); Zgornji Razbor, 700 m.

Chiloscyphus profundus (Nees) J. J. Engel et R. M. Schust. - temp: Peč, pri planinskem domu Tromeja, $1200 \mathrm{~m}$; Medvedjek nad Podkorenom, 1000 m; Krvavka, 1000 m; Struška Kočna, 1600 m; planina Pusti rovt pod Korenščico, 1500 m; Gozdašnica, nad dolino Završnico, 800 m; Debelo Brdo pod Belščico, 1200 m; pri Valvazorjevem domu pod Stolom, $1200 \mathrm{~m}$; dolina Završnica, 800 m; Ljubelj, 1000 m; Spodnje Jezersko: Tisovec, 850 m; Zgornje Jezersko: pod Roblekom, 1000 m; pod Pavličevim sedlom, 
barje blizu kmetije Covnik, 1150 m (Martinčič 2003); pod Pavličevim sedlom, pri kmetiji Covnik, 1200 m; Olševa: Zadnji travnik, 1400 m; Olševa, sev. pobočje, 1300 m; Najbrževo pod Malo Peco, 1400 m (Kutnar et al. 2006, det. Martinčič); dolina Koprivna, 950 m; dolina Topla, pri Florinu, $900 \mathrm{~m}$; dolina Topla, nad Fajmutom, 1100 m; Olševa, pod Potočko zijalko, 1600 m; Strevčev vrh pri Olševi, nad Rogarjem, 1400 m; pri Črni na Koroškem, proti Javorju, $650 \mathrm{~m}$; dolina reke Bistre, $650 \mathrm{~m}$; Uršlja gora, $1400 \mathrm{~m}$; Bačovski vrh, 1000 m; Zgornji Razbor, 700 m; Javorniško sedlo (za Storžičem), 1400 m.

Cololejeunea calcarea (Lib.) Schiffn. - bor-temp: Begunjščica, zah. pobočje; Begunjščica, 1300 m (Martinčič 2003); Vranček pod Ljubeljem, 850 m; Ljubelj, 1000 m; pod Javorniškim sedlom (za Storžičem), $800 \mathrm{~m}$.

Conocephalum conicum (L.) Dumort. - subbor: Rateče, 900 m; Srednji vrh nad Gozd Martuljkom, ob potoku Jerman, 1000 m (Martinčič 2010); Klek, 1600 m; Sv. Križ pri Planini pod Golico, 1000 m; Črni vrh nad Jesenicami, 1400 m; Velika Golica, 1400 m; Krvavka, 1000 m; Hruška planina pod Rožco, 1000 m; planina Pusti rovt pod Korenščico, 1500 m; Struška Kočna, 1600 m; Medji dol, 1000 m; Vajnež, 2100 m; Potoška planina pod Belščico, $1300 \mathrm{~m}$; pri Valvazorjevem domu pod Stolom, $1200 \mathrm{~m}$; dolina Završnica, $800 \mathrm{~m}$; Ljubelj, $1000 \mathrm{~m}$; Lajb pod Ljubeljem, 750 m; Jelendol, pod Penatco, 900 m; Zgornje Jezersko: pod Roblekom, 1000 m; pod Pavličevim sedlom, pri kmetiji Covnik, 1200 m; dolina Koprivna, $900 \mathrm{~m}$; Najbrževo pod Malo Peco, 1400 m (Kutnar 2006, det. Martinčič); dolina Topla, $750 \mathrm{~m}$; Olševa, Potočka zijalka, vhod, 1700 m; Strevčev vrh pri Olševi, nad Rogarjem, 1400 m; Sv. Duh pod Olševo, pri Potočniku, 1200 m; Jazbina pri Žerjavu, 680 m (Piskernik 1977, det. Martinčič); Kozarnica, vzh. od Uršlje gore, 1150 m (Grom LJU 1958); Uršlja gora, 1500 m; Čadovlje pri Tržiču, 600 m; Dolžanova soteska pri, vasi Dolina, $750 \mathrm{~m}$.

Diplophyllum albicans (L.) Dumort. - bor-temp: Črni vrh nad Jesenicami, 1400 m; med Hruško planino in Sv. Križem pri Planini pod Golico, 1100 m; Javorniški Rovt, 1100 m; Debelo brdo pod Belščico, 1200 m (Martinčič 2010); pri Valvazorjevem domu pod Stolom, 1200 m; Jelendol (Grom LJU 1959); Zgornje Jezersko: pod Roblekom, $1000 \mathrm{~m}$; pod Pavličevim sedlom, pri kmetiji Covnik, $1200 \mathrm{~m}$; pod Pavličevim sedlom, 1250 m (Grom LJU 1970); dolina Ko- privna, $950 \mathrm{~m}$; dolina Topla, pod Florinom, 900 m; dolina Topla, nad Fajmutom, 1400 m; dolina Topla, pod Burjakovim hribom, 700 m; Strevčev vrh pri Olševi, $1500 \mathrm{~m}$ (Martinčič 2010); dolina reke Bistre pri Črni na Koroškem, 650 m; Ludranski vrh (Grom LJU 1960); pri Črni na Koroškem, proti Javorju, 650 m; Zgornji Razbor, 700 m; Javornik (za Storžičem), (Deschmann 1869).

Diplophyllum taxifolium (Wahlenb.) Dumort. subarkt-subalp: Olševa, Zadnji travnik, $1400 \mathrm{~m}$ (Martinčič 2010).

Frullania dilatata (L.) Dumort. - merid-temp: Peč, 1100 m; na Trebižah nad Ratečami, 1100 m; Srednji vrh nad Gozd Martuljkom, 950 m; nad Gozd Martuljkom, 800 m; nad Dovjem, 800 m; pri Valvazorjevem domu, pod Stolom, 1200 m; dolina Završnica, $800 \mathrm{~m}$; Lajb pod Ljubeljem, 750 m; Jelendol, pod Penatco, 900 m; Medvodje pod Penatco, $850 \mathrm{~m}$; Spodnje Jezersko: Tisovec, $850 \mathrm{~m}$; Zgornje Jezersko: pod Roblekom, $1000 \mathrm{~m}$; pod Pavličevim sedlom, pri kmetiji Covnik, 1200 m; Strevčev vrh pri Olševi, nad Rogarjem, 1400 m (Martinčič 2010); Draga pri Begunjah na Gorenjskem, 690 m; Čadovlje pri Tržiču, $600 \mathrm{~m}$; Dolžanova soteska, pri vasi Dolina, $600 \mathrm{~m}$.

Frullania fragilifolia (Tayl.) Gottsche et al. temp: pod Pavličevim sedlom, pri kmetiji Covnik, 1200 m (Martinčič 2010).

Frullania jackii Gottsche - temp-subkont: Dolžanova soteska, pri vasi Dolina, 750 m (Martinčič 2010).

Fungermannia atrovirens Dumort. - bor-temp: Medji dol, $1000 \mathrm{~m}$ (Martinčič 2010); med Javornikom (Jesenice) in Javorniškim Rovtom, $600 \mathrm{~m}$; pri Valvazorjevem domu pod Stolom, $1100 \mathrm{~m}$; dolina Završnica, pod Begunjščico, $1000 \mathrm{~m}$; Spodnje Jezersko: Tisovec, $850 \mathrm{~m}$ (Martinčič 2010); Javorniško sedlo (za Storžičem), $1400 \mathrm{~m}$.

*DD-fungermannia confertissima Nees - arkt-alp: Javorniško sedlo (za Storžičem), 1400 m.

fungermannia gracillima Sm. - temp: pri Črni na Koroškem, proti Javorju, 650 m (Martinčič 2010).

Fungermannia hyalina Lyell - temp: med Hruško planino in Sv. Križem pri Planini pod Golico, 1100 m; Javorniški Rovt, 1100 m (Martinčič 2010); Begunjščica, 1200 m (Martinčič 2010).

fungermannia leiantha Grolle - bor-mont: med Hruško planino in Sv. Križem pri Planini pod Golico, 1100 m; Javorniški Rovt, 1100 m (Mar- 
tinčič 2010); Medji dol, 1000 m; planina Pusti rovt pod Korenščico, 1500 m; med Javornikom (Jesenice) in Javorniškim Rovtom, 900 m; Debelo brdo pod Belščico, $1200 \mathrm{~m}$; dolina Završnica, 800 m; Stol, 1900 m (Martinčič 2010); Zgornji Razbor, 700 m; Čadovlje pri Tržiču, $600 \mathrm{~m}$; Dolžanova soteska pri Tržiču, $600 \mathrm{~m}$.

fungermannia polaris Lindb. - arkt-alp: Dolžanova soteska pri Tržiču, Hudičev most (Glowacki 1912).

Jungermannia sphaerocarpa Hook. - bor-mont: Javorniški Rovt, 1100 m (Martinčič 2010); Stol, $2100 \mathrm{~m}$.

Fungermannia subulata A. Evans - temp-subkont: Krvavka, 1000 m; Črni vrh nad Jesenicami, 1400 m (Martinčič 2010); med Hruško planino in Sv. Križem pri Planini pod Golico; Medji dol, 1000 m; Javorniški Rovt, 1100 m (Martinčič 2010); med Javornikom (Jesenice) in Javorniškim Rovtom, $800 \mathrm{~m}$.

Lejeunea cavifolia (Ehrh.) Lindb. - ubikv: nad Gozd Martuljkom, 800 m; Črni vrh nad Jesenicami, 1400 m; Gozdašnica nad dolino Završnico, 800 m; Debelo Brdo pod Belščico, 1200 m; dolina Završnica, $800 \mathrm{~m}$; pod Ljubeljem, $950 \mathrm{~m}$; Jelendol, pod Penatco, 900 m (Martinčič 2011); pod Pavličevim sedlom, pri kmetiji Covnik, 1200 m; dolina Koprivna, 950 m; Črna na Koroškem, ob reki Bistri, $620 \mathrm{~m}$ (Juvan 2008); Spodnji Razbor pri Mislinjski Dobravi, $500 \mathrm{~m}$ (Martinčič 2011); Čadovlje pri Tržiču, 600 m; Dolžanova soteska, pri vasi Dolina, $750 \mathrm{~m}$.

Lepidozia reptans (L.) Dumort. - bor-temp: Medvedjek nad Podkorenom, 1000 m; nad Gozd Martuljkom, $800 \mathrm{~m}$; med Hruško planino in Sv. Križem pri Planini pod Golico, 1100 m; Črni vrh nad Jesenicami, $1400 \mathrm{~m}$; Javorniški Rovt, 1100 m; Debelo brdo pod Belščico, $1200 \mathrm{~m}$; med Javornikom (Jesenice) in Javorniškim Rovtom, 800 m; Potoška planina pod Belščico, $1300 \mathrm{~m}$; Vranček pod Ljubeljem, 850 m; Jelendol (Grom LJU 1959, det. Martinčič); Spodnje Jezersko: Tisovec, $850 \mathrm{~m}$; Zgornje Jezersko: pod Roblekom, 1000 m; pod Pavličevim sedlom, pri kmetiji Covnik, 1200 m; Olševa, sev. pobočje, $1300 \mathrm{~m}$; Olševa, $1400 \mathrm{~m}$ (Kutnar et al. 2006, det. Martinčič); Janškov vrh nad reko Mežo, 1050 m (Grom LJU 1960, det. Martinčič); Sleme nad dolino Koprivno (Grom LJU 1964); dolina Koprivna, 950 m; dolina Topla, pri Florinu, $900 \mathrm{~m}$; dolina Topla, nad Fajmutom, 1400 m; Najbrževo pod Malo peco, 1400 m (Kutnar et al. 2006, det. Martin- čič); Huda peč nad Solčavo, 1200 m (Martinčič 2011); Strevčev vrh pri Olševi, nad Rogarjem, 1400 m; Olševa, pod Potočko zijalko, 1600 m; Ludranski vrh: Podgora (Grom LJU 1960); pri Črni na Koroškem, proti Javorju, 650 m; Uršlja gora, $1400 \mathrm{~m}$; Bačovski vrh, $1000 \mathrm{~m}$; Gornji Razbor, 700 m; Blatnica, vzh. od Uršlje gore, $820 \mathrm{~m}$ (Piskernik 1977, det. Martinčič); Čadovlje pri Tržiču, $800 \mathrm{~m}$.

*DD-n-Lophozia ascendens (Warnst.) R.M. Schust. - bor-mont: Olševa, sev. pobočje, $1300 \mathrm{~m}$.

Lophozia badensis (Gottsche) Schiffn. - bor-mont: Spodnje Jezersko: Tisovec, $850 \mathrm{~m}$ (Martinčič 2011).

Lophozia bantriensis (Hook.) Steph. - bor-mont: pri Valvazorjevem domu, pod Stolom, $1400 \mathrm{~m}$ (Martinčič 2010).

Lophozia collaris (Nees) Dumort. - bor-mont: Srednji vrh nad Gozd Martuljkom, 1000 m; Krvavka, 1400 m; med Hruško planino in Sv. Križem pri Planini pod Golico, $1100 \mathrm{~m}$; Črni vrh nad Jesenicami, $1400 \mathrm{~m}$; Medji dol, $1000 \mathrm{~m}$; planina Pusti rovt pod Korenščico, 1500 m; pri Valvazorjevem domu, pod Stolom, 1200 m; dolina Završnica, pod Begunjščico, 1000 m (Martinčič 2011); Begunjščica, 1500 m; Ljubelj, 1000 m; Vranček pod Ljubeljem, 850 m; Spodnje Jezersko: Tisovec, $850 \mathrm{~m}$; dolina Topla, pri Florinu, 900 m; Strevčev vrh pri Olševi, nad Rogarjem, 1400 m (Martinčič 2011); Uršlja gora, 1500 m; Javorniško sedlo (za Storžičem), $1400 \mathrm{~m}$.

Lophozia elongata (Lindb.) Steph. - bor-mont: Uršlja gora, $1500 \mathrm{~m}$.

Lophozia heterocolpos (Thed. ex C. Hartm.) M. Howe - subarkt-subalp: Medvedjek nad Podkorenom, 1000 m; Struška Kočna, 1600 m; Vajnež, 2100 m (Martinčič 2011); Stol, 2200 m; dolina Topla, pri Florinu, $900 \mathrm{~m}$; Uršlja gora, 1500 m (Martinčič 2011); Draga pri Begunjah na Gorenjskem, $690 \mathrm{~m}$.

Lophozia incisa (Schrad.) Dumort. - bor-mont: dolina Završnica, pod Begunjščico, $1000 \mathrm{~m}$ (Martinčič 2011); Jelendol, pod Košuto (Grom LJU 1959, det. Martinčič).

Lophozia ventricosa (Dicks.) Dumort var. ventricosa - bor-mont: Struška Kočna, 1700 m; Debelo brdo pod Belščico, 1200 m (Martinčič 2010); dolina Koprivna, 950 m (Martinčič 2010); Javorniško sedlo (za Storžičem), $1300 \mathrm{~m}$.

VU-Marchantia polymorpha L. subsp. polymorpha L. - bor-temp: Potoška planina pod Belščico 1300 m (Martinčič 2007).

Marchantia polymorpha L. subsp. montivagans 
Bischl. et Boisselier - bor-temp: Peca, $1600 \mathrm{~m}$ (Dolšak LJU 1931, det. Martinčič, Martinčič 2007); Olševa, 1900 m (Breidler 1894).

Marchantia polymorpha L. subsp. ruderalis $\mathrm{Bi}-$ schl. et Boisselier - bor-temp: Velika Golica, 1400 m; med Jesenicami in Sv. Križem pri Planini pod Golico, 1000 m; Črni vrh nad Jesenicami, 1400 m; Vajnež, 2100 m (Martinčič 2003); Uršlja gora, 1500 m (Martinčič 2003).

Metzgeria conjugata Lindb. - bor-temp: Medvedjek nad Podkorenom, 1000 m; Srednji vrh nad Gozd Martuljkom, 1000 m; Črni vrh nad Jesenicami, 1400 m (Martinčič 2011); Medji dol, 1000 m; Javorniški Rovt, 1100 m; Debelo brdo pod Belščico, $1200 \mathrm{~m}$; pri Valvazorjevem domu, pod Stolom, 1200 m; Begunjščica, 900 m; Ljubelj, 1000 m; Jelendol (Grom LJU 1959); Jelendol, pod Penatco, $900 \mathrm{~m}$; Spodnje Jezersko: Tisovec, $850 \mathrm{~m}$; pod Pavličevim sedlom, pri kmetiji Covnik, 1200 m; dolina Koprivna, $900 \mathrm{~m}$; Uršlja gora, pri kmetiji Plešivec, $950 \mathrm{~m}$ (Martinčič 2011); Podljubelj, 1000 m (Grom LJU 1963); Čadovlje pri Tržiču, 600 m; Dolžanova soteska, pri vasi Dolina, $750 \mathrm{~m}$.

Metzgeria furcata (L.) Dumort. - bor-temp: Peč, pri planinskem domu Tromeja, $1200 \mathrm{~m}$; Medvedjek nad Podkorenom, 1000 m; Srednji vrh nad Gozd Martuljkom, 1000 m (Martinčič 2011); Krvavka, 1750 m; Velika Golica, vrh, 1800 m; Debelo brdo pod Belščico, 1200 m; Ljubelj, 1000 m; Jelendol, proti Čizovcu, 1400 m (Marinček \& Čarni 2010); Jelendol, pod Penatco, 900 m; Strevčev vrh pri Olševi, nad Rogarjem, 1400 m; Uršlja gora, vzh. pobočje, 1100 m; Uršlja gora, pri kmetiji Plešivec, $950 \mathrm{~m}$.

var. ulvula Nees: Jelendol, pod Penatco, 900 m; Strevčev vrh pri Olševi, nad Rogarjem, $1400 \mathrm{~m}$ (Martinčič 2011).

VU-Mylia anomala (Hook.) Gray - bor-mont: Olševa: barje Zadnji travnik, 1340 m (Piskernik \& Martinčič 1970).

Mylia taylorii (Hook.) Gray - bor-mont: Javornik pri Jesenicah (Paulin LJU 1900); dolina Topla, pod Florinom, 850 m (Martinčič 2011); Olševa, vzh. rob, 1320 m (Grom LJU 1970, det. Martinčič).

Nardia scalaris Gray - bor-temp: Hruški vrh, 1700 m (Martinčič 2011); Olševa: Zadnji travnik, $1400 \mathrm{~m}$ (Martinčič 2011); dolina Topla, pri Florinu, 900 m; Javorniško sedlo (za Storžičem), $1400 \mathrm{~m}$.

Nowellia curvifolia (Dicks.) Mitt. - bor-temp: med Hruško planino in Sv. Križem pri Pla- nini pod Golico, $1100 \mathrm{~m}$; planina Pusti rovt pod Korenščico, 1500 m; Debelo Brdo pod Belščico, $1200 \mathrm{~m}$ (Martinčič 2011); dolina Završnica, 800 m; Ljubelj, 1000 m; Jelendol, pod Penatco, $900 \mathrm{~m}$; Zgornje Jezersko: pod Roblekom, $1000 \mathrm{~m}$; pod Pavličevim sedlom, pri kmetiji Covnik, 1200 m; Olševa, sev. pobočje, 1300 m; dolina Koprivna, 900 m; dolina Topla pri Florinu, $900 \mathrm{~m}$; Olševa: pod Potočko zijalko, 1600 m; Strevčev vrh pri Olševi, nad Rogarjem, 1400 m; pri Črni na Koroškem, proti Javorju, $650 \mathrm{~m}$; Bačovski vrh, $1000 \mathrm{~m}$.

Odontoschisma denudatum (Mart.) Dumort. bor-temp: Medvedjek nad Podkorenom, $1000 \mathrm{~m}$ (Martinčič 2011); dolina Topla, 750 m; Zgornji Razbor, $700 \mathrm{~m}$.

Pedinophyllum interruptum (Nees) Kaal. - temp: Vrhe pri Slovenjgradcu, $530 \mathrm{~m}$; Srednji vrh nad Gozd Martuljkom, ob potoku Jerman, 1000 m; Velika Golica, 1400 m; Črni vrh nad Jesenicami, $1400 \mathrm{~m}$; Ljubelj, $1000 \mathrm{~m}$; Jelendol, pod Penatco, 900 m (Martinčič 2011); grad Kamen pri Begunjah na Gorenjskem (Glowacki 1912); Čadovlje pri Tržiču, 600 m; Dolžanova soteska, pri vasi Dolina, $750 \mathrm{~m}$.

Pellia endiviifolia (Dicks.) Dumort. - merid-temp: Srednji vrh nad Gozd Martuljkom, 1000 (Martinčič 2011); Sv. Križ pri Planini pod Golico, 1000 m; Črni vrh nad Jesenicami, 1400 m; Javorniški Rovt, 1100 m; dolina Završnica, 800 m; Zgornje Jezersko: pod Roblekom, 1000 m; pod Pavličevim sedlom, pri kmetiji Covnik, 1200 m; dolina Koprivna, 900 m; Olševa: Zadnji travnik, 1400 m; dolina Topla, nad Fajmutom, 1100 m; dolina reke Bistre pri Črni na Koroškem, 650 m; pri Črni na Koroškem, proti Javorju, 650 m; Plešivški mlin pod Uršljo goro, 900 m (Martinčič 2011); Uršlja gora, 1600 m; Zgornji Razbor, 700 m; Spodnji Razbor pri Mislinjski Dobravi, $500 \mathrm{~m}$; Čadovlje pri Tržiču, $600 \mathrm{~m}$.

Pellia epiphylla (L.) Corda - bor-temp: Zgornje Jezersko: pod Roblekom, 1000 m; pri Črni na Koroškem, proti Javorju, 650 m (Martinčič 2011).

Pellia neesiana (Gottsche) Limpr. - bor-mont: med Hruško planino in Sv. Križem pri Planini pod Golico, 1100 m (Martinčič 2011); Spodnje Jezersko: Tisovec, 850 m; Zgornje Jezersko: pod Roblekom, $1000 \mathrm{~m}$.

*Peltolepis quadrata (Saut.) Müll. Frib. - arkt-alp: Vajnež, $2100 \mathrm{~m}$.

Plagiochila asplenioides (L. em. Tayl.) Dumort. - temp: Hruška planina pod Rožco, 1200 m; Sv. Križ pri Planini pod Golico, 1000 m; Spo- 
dnje Jezersko: Tisovec, $850 \mathrm{~m}$; pod Pavličevim sedlom, pri kmetiji Covnik, 1200 m; pod Pavličevim sedlom (Grom LJU 1970); Olševa: Zadnji travnik, 1400 m; Javorje pod Malo Peco, 1320 m (Kutnar et al. 2006, det. Martinčič); dolina Koprivna, 1200 m; Janškov vrh nad reko Mežo (Grom LJU 1960); pod Olševo (Grom LJU 1970); Strevčev vrh pri Olševi, 1400 m; dolina reke Bistre, 650 m; Zgornji Razbor pri Slovenjgradcu, $700 \mathrm{~m}$.

Plagiochila porelloides (Torrey ex Nees) Lindenb. - subbor: Medvedjek nad Podkorenom, 1000 m; nad Gozd Martuljkom, 800 m; Dovška Baba, 1800 m; Črni vrh nad Jesenicami, 1400 m; Klek, 1600 m; Krvavka, 1750 m; Korenščica, 1500 m; Medji dol, 1000 m; Debelo brdo pod Belščico, 1200 m; Vajnež, 2100 m; pri Javorniškem Rovtu 1100 m; Begunjščica, 1200 m, 2000 m; dolina Završnica, pod Begunjščico, $1000 \mathrm{~m}$; Stol, 1800 m; Ljubelj, 1000 m; Jelendol (Grom LJU 1959); Jelendol, pod Penatco, $900 \mathrm{~m}$; Zgornje Jezersko: pod Roblekom, 1000 m; pod Pavličevim sedlom, pri kmetiji Covnik, 1200 m; Olševa, Zadnji travnik, $1400 \mathrm{~m}$; Olševa, sev. pobočje, 1300 m; dolina Koprivna, 900 m, 1200 m; dolina Topla, nad Fajmutom, 1100 m; Olševa, 1400 m (Kutnar et al. 2006, det. Martinčič); Olševa (Grom LJU 1960); Olševa: pri Potočki zijalki, 1700 m (Grom LJU 1970); Olševa, juž. pobočje; Strevčev vrh pri Olševi, 1500 m; Ludranski vrh (Grom LJU 1960); dolina reke Bistre, 650 m; Uršlja gora: Črni vrh (Grom LJU 1958); Uršlja gora, 1600 m (Martinčič 2011); Zgornji Razbor pri Slovenj Gradcu, 700 m; Podljubelj (Grom LJU 1961); Čadovlje pri Tržiču, 600 m; Dolžanova soteska, pri vasi Dolina, $750 \mathrm{~m}$.

Porella cordaeana (Hueben.) Moore - bor-temp: Medji dol, 1000 m; Begunjščica, 2000 m (Martinčič 2011); Uršlja gora, 1600 m (Martinčič 2011).

Porella obtusata (Tayl.) Trevis. - merid-temp: nad Dovjem, $800 \mathrm{~m}$; Lajb pod Ljubeljem, $750 \mathrm{~m}$; Čadovlje pri Tržiču, $600 \mathrm{~m}$.

Porella platyphylla (L.) Pfeiff. - bor-temp: na Trebižah nad Ratečami, 1100 m; Rateče, 900 m; nad Gozd Martuljkom, 800 m; Srednji vrh nad Gozd Martuljkom, 950 m (Martinčič 2011); nad Dovjem, 800 m; Begunjščica, 2000 m; Ljubelj, 1000 m; Lajb pod Ljubeljem, 750 m; Koprivna, pri kmetiji Kumar, 1300 m; Olševa, pod Potočko zijalko, 1600 m; Peca, 1700 m (Martinčič 2003, leg. M. Zupančič); Uršlja gora, vzh. pobočje, $1100 \mathrm{~m}$; Čadovlje pri Tržiču, $600 \mathrm{~m}$.
Preissia quadrata (Scop.) Nees - bor-mont: Rateče, $900 \mathrm{~m}$; Srednji vrh nad Gozd Martuljkom, 950 m; Velika Golica, 1800 m; Črni vrh nad Jesenicami, 1400 m; Krvavka, 1750 m; Vajnež, 2100 m; Debelo brdo pod Belščico, 1200 m; Stol-Belščica (Deschmann 1858); Stol, 2000 m; Ljubelj, 1000 m; Vranček pod Ljubeljem, $850 \mathrm{~m}$; dolina Topla, $800 \mathrm{~m}$; Jelendol pod Penatco, $900 \mathrm{~m}$; Spodnje Jezersko: Tisovec, 850 m (Martinčič 2011); Najbrževo pod Malo peco, $1400 \mathrm{~m}$ (Kutnar et al. 2006, det. Martinčič); dolina Topla, pri Florinu, $900 \mathrm{~m}$; Črna na Koroškem, breg reke Bistre, $620 \mathrm{~m}$ (Juvan 2008); dolina reke Bistre pri Črni na Koroškem, 650 m; Uršlja gora, vzh. pobočje, 1100 m; Podgorje pri Slovenj Gradcu, 450 m; Čadovlje pri Tržiču, $600 \mathrm{~m}$; Javorniško sedlo (za Storžičem), 1400 m; Dolžanova soteska, pri vasi Dolina, $750 \mathrm{~m}$.

Ptilidium ciliare (L.) Hampe - bor-mont: Korenščica, $1500 \mathrm{~m}$; Potoška planina pod Belščico, 1300 m; Begunjščica, 1900 m (Martinčič 2011); pod Pavličevim sedlom, pri kmetiji Covnik, 1200 m; Olševa, Zadnji travnik, 1400 m; Najbrževo pod Malo Peco, 1400 m ( leg. Čas); Strevčev vrh pri Olševi, nad Rogarjem, 1400 m (Martinčič 2011); Uršlja gora, 1400 m; Uršlja gora, 1300 m (Piskernik 1977, det. Martinčič).

Ptilidium pulcherrimum (Web.) Vain. - bor-mont: Peč, 1100 m; Petelinjek nad Korenskim sedlom, 1425 m (Martinčič 2003); Klek, 1600 m; Medji dol, $1000 \mathrm{~m}$; Potoška planina pod Belščico, 1300 m (Martinčič 2003); Najbrževo pod Malo Peco, 1400 m (Kutnar et al. 2006, det. Martinčič); Olševa, Zadnji travnik, 1300 m ( Piskernik \& Martinčič 1970, Martinčič 2003); Olševa, pod Potočko zijalko, 1600 m; Strevčev vrh pri Olševi, $1400 \mathrm{~m}$; Uršlja gora, $1100 \mathrm{~m}$.

Radula complanata (L.) Dumort. - bor-temp: na Trebižah nad Ratečami, 1100 m; Medvedjek nad Podkorenom, 1000 m (Martinčič 2011); Peč, pri planinskem domu Tromeja, $900 \mathrm{~m}$; Rateče, 900 m; Srednji vrh nad Gozd Martuljkom, 950 m; nad Dovjem, 800 m; med Hruško planino in Sv. Križem pri Planini pod Golico, 1100 m; Krvavka, 1600 m; Hruški vrh, 1700 m; Medji dol, 1000 m; Begunjščica, 2000 m; Begunjščica, nad Poljško planino, $1500 \mathrm{~m}$; Stol $2000 \mathrm{~m}$; dolina Završnica, $800 \mathrm{~m}$; Ljubelj, 1000 m; Lajb pod Ljubeljem, 750 m; Vranček pod Ljubeljem, $850 \mathrm{~m}$; Medvodje, pod Penatco, 850 m; Jelendol, pod Penatco, 900 m; Spodnje Jezersko: Tisovec, $850 \mathrm{~m}$; pod Pavličevim se- 
dlom, pri kmetiji Covnik, $1200 \mathrm{~m}$; Javorje pod Malo Peco, $1320 \mathrm{~m}$ (Kutnar et al. 2006, det. Martinčič); dolina Topla pod Florinom, $850 \mathrm{~m}$ (Martinčič 2011); Olševa, juž. pobočje, 800 m; Olševa, pod Potočko zijalko, 1600 m; Strevčev vrh pri Olševi, nad Rogarjem, 1400 m; Uršlja gora, $1600 \mathrm{~m}$; pod Uršljo goro, pri kmetiji Plešivec, $950 \mathrm{~m}$; Podgorje pri Slovenj Gradcu, 450 m; Spodnji Razbor pri Mislinjski Dobravi, $500 \mathrm{~m}$; Draga pri Begunjah na Gorenjskem, 690 m; Čadovlje pri Tržiču, 600 m; Dolžanova soteska pri Tržiču, $600 \mathrm{~m}$; Javornik (za Storžičem), (Deschmann 1869).

Radula lindenbergiana Gottsche ex C. Hartm. - submed-temp: Medji dol, 1000 m (Martinčič 2011); Korenščica, 1700 m; Jelendol, pod Penatco, 900 m (Martinčič 2011).

Reboulia hemisphaerica (L.) Raddi - submed-temp: Stol, 1800 m (Martinčič 2011); Javorniško sedlo (za Storžičem), $1400 \mathrm{~m}$.

Riccardia chamaedryfolia (With.) Grolle - bor-temp: Javorniški Rovt, 1100 m (Martinčič 2011); Medji dol, 1000 m; Debelo brdo pod Belščico, $1200 \mathrm{~m}$; pri Valvazorjevem domu pod Stolom, 1200 m; dolina Topla, 750 m (Martinčič 2011); Zgornji Razbor, $700 \mathrm{~m}$.

Riccardia latifrons (Lindb.) Lindb. - subbor: dolina Topla, 750 m (Martinčič 2011); Bačovski vrh, 1000 m (Martinčič 2011).

Riccardia palmata (Hedw.) Carruth. - bor-mont: Klek, 1600 m; med Hruško planino in Sv. Križem pri Planini pod Golico, $1100 \mathrm{~m}$; Medji dol, $1000 \mathrm{~m}$; Potoška planina pod Belščico, $1300 \mathrm{~m}$; Debelo brdo pod Belščico, $1200 \mathrm{~m}$; Ljubelj, 1000 m; Jelendol, pod Penatco, 900 m (Martinčič 2011); Zgornje Jezersko: pod Roblekom, $1000 \mathrm{~m}$; pod Pavličevim sedlom, pri kmetiji Covnik, 1200 m; dolina Koprivna, 900 m (Martinčič 2011); dolina Topla, 750 m; Čadovlje pri Tržiču, 600 m; Javorniško sedlo (za Storžičem), $1400 \mathrm{~m}$.

Sauteria alpina (Nees) Nees - arkt-alp: Peca (Dolšak LJU 1936).

Scapania aequiloba (Schwaegr.) Dumort. - bor-mont: Medvedjek nad Podkorenom, 1000 m; Črni vrh nad Jesenicami, 1400 m (Martinčič 2011); Krvavka, 1600 m; Korenščica, 1500 m; Jelendol (Grom LJU 1959, det. Martinčič); Olševa, sev. pobočje, 1300 m; Ravnjakov vrh nad Prevaljami, 910 m (Grom LJU 1958, det. Martinčič).

Scapania aspera Bernet et M. Bernet - bor-temp: Čadovlje pri Tržiču, 600 m; Dolžanova soteska pri Tržiču, $600 \mathrm{~m}$.
Scapania curta (Mart.) Dumort. - subbor: Olševa, Zadnji travnik, $1400 \mathrm{~m}$.

Scapania irrigua (Nees) Nees - bor-mont: Uršlja gora, $1650 \mathrm{~m}$.

Scapania nemorea (L.) Grolle - bor-temp: Martuljek pri Kranjski Gori, 900 m (Dolšak LJU 1923, rev. Martinčič); med Hruško planino in Sv. Križem pri Planini pod Golico, 1100 m; Javorniški Rovt, 1000 m; med Javornikom (Jesenice) in Javorniškim Rovtom, 800 m; pri Valvazorjevem domu pod Stolom, 1200 m; dolina Topla, $750 \mathrm{~m}$.

Scapania subalpina (Nees ex Lindenb.) Dumort. - subarkt-subalp: Krvavka, 1600 m; Olševa, sev. pobočje, $1300 \mathrm{~m}$; dolina Topla, $800 \mathrm{~m}$.

Scapania umbrosa (Schrad.) Dumort. - bor-mont: Olševa, sev. pobočje, $1300 \mathrm{~m}$; Javorniško sedlo (za Storžičem), $1400 \mathrm{~m}$.

Scapania undulata (L.) Dumort. - bor-temp: med Hruško planino in Sv. Križem pri Planini pod Golico, 1100 m (Martinčič 2011).

Trichocolea tomentella (Ehrh.) Dumort. - temp: pod Pavličevim sedlom, pri kmetiji Covnik, 1150 m; Strevčev vrh pri Olševi, nad Rogarjem, 1400 m (Martinčič 2003); Sv. Duh pri Solčavi, pod Olševo (Grom LJU 1960); Zgornji Razbor, $700 \mathrm{~m}$.

Tritomaria exsecta (Schmidel) Loeske - bor-mont: Javorniški Rovt, 1100 m (Martinčič 2011); dolina Završnica, pod Begunjščico, 1000 m; Jelendol (Grom LJU 1959, det. Martinčič); dolina Koprivna, 950 m (Martinčič 2011); Olševa, sev. pobočje, $1300 \mathrm{~m}$ (leg. Čas); Javorniško sedlo (za Storžičem), $1400 \mathrm{~m}$.

VU-Tritomaria exsectiformis (Breid.) Loeske subsp. exsectiformis - bor-mont: Korenščica, 1500 m (Martinčič 2011).

Tritomaria quinquedentata (Huds.) H. Buch - bor-mont: Korenščica, 1700 m; Stol, 2000 m (Martinčič 2011); Javorniško sedlo (za Storžičem), 1400 m (Martinčič 2011).

\section{Bryophyta - listnati mahovi}

Abietinella abietina (Hedw.) M. Fleisch. - ubikv: nad Ratečami, 1000 m; nad Podkorenom, 950 m; Dovška Baba, 1800 m; nad Dovjem, 800 m; Velika Golica, 1400 m (Müllner 1893); pri Valvazorjevem domu pod Stolom, $1200 \mathrm{~m}$; dolina Završnica, pod Begunjščico 1000 m; Ljubelj: Sv. Ana, 900 m; Spodnje Jezersko: Tisovec, 850 m; Zgornje Jezersko: pod Roblekom, 1000 m; pod 
Pavličevim sedlom, pri kmetiji Covnik, 1200 m; dolina Topla, nad Fajmutom, 1400 m; Sv. Duh pod Olševo, pri Potočniku, 1200 m; Knezove peči nad dolino reke Bistre (Grom LJU 1960); Uršlja gora: Kozakinovo; Draga pri Begunjah na Gorenjskem, 690 m (Piskernik 1977, det. Martinčič); Dobrča (Piskernik 1977, det. Martinčič); Stolec nad Tržičem, $560 \mathrm{~m}$.

Aloina rigida (Hedw.) Limpr. - temp: Uršlja gora, vznožje (Wallnöfer 1888).

Amblystegium confervoides Schimp. - bor-temp: Begunjščica, nad Poljško planino, $1500 \mathrm{~m}$; Jelendol, pod Penatco, $900 \mathrm{~m}$; dolina Topla, nad Fajmutom, 1100, 1400 m (Martinčič 2012).

Amblystegium radicale (P. Beauv.) Schimp. temp: Podljubelj (Martinčič 1976); Sv. Peter nad Begunjami na Gorenjskem, 700 m (Piskernik 1977, det. Martinčič).

Amblystegium serpens (Hedw.) Schimp. - ubikv: med Gozd Martuljkom in Belco, $700 \mathrm{~m}$; med Hruško planino in Sv. Križem pri Planini pod Golico, 1000 m (Martinčič 2012); pod Pavličevim sedlom, pri kmetiji Covnik, 1200 m; Koprivna, pri kmetiji Kumar, 1300 m; Strevčev vrh pri Olševi, nad Rogarjem, 1400 m; dolina reke Bistre, $650 \mathrm{~m}$; Smokuč pri Begunjah na Gorenjskem, $540 \mathrm{~m}$; Čadovlje pri Tržiču, $600 \mathrm{~m}$.

*var. juratzkanum - temp: nad Dovjem, 800 m; Struška Kočna, 1600 m;

Amblystegium subtile (Hedw.) Schimp. - tempsubkont: nad Podkorenom, 950 m; Sv. Križ pri Planini pod Golico, 1000 m; Medji dol, 1000 m; Jelendol, pod Penatco, 900 m; pod Pavličevim sedlom, pri kmetiji Covnik, $1200 \mathrm{~m}$; dolina Topla, pod Burjakovim hribom, $700 \mathrm{~m}$; dolina Topla, nad Fajmutom, 1100 m; Strevčev vrh pri Olševi, nad Rogarjem, 1400 m; Jazbina pri Žerjavu, $680 \mathrm{~m}$ (Piskernik 1977, det. Martinčič); Kozarnica, vzh. od Uršlje gore, $1000 \mathrm{~m}$ (Piskernik 1977, det. Martinčič); Uršlja gora, vzh. pobočje, $1100 \mathrm{~m}$; Uršlja gora, pri kmetiji Plešivec, 950 m; Spodnji Razbor pri Mislinjski Dobravi, 500 m; Draga pri Begunjah na Gorenjskem, $690 \mathrm{~m}$.

Amphidium mougeotii (Schimp.) Schimp. - bor-mont: dolina Koprivna: Sv. Jakob (Glowacki 1908); dolina Topla, pod Florinom, $850 \mathrm{~m}$; dolina Topla, pod Burjakovim hribom, $700 \mathrm{~m}$; Črna na Koroškem, breg reke Bistre, $620 \mathrm{~m}$ (Juvan 2008); dolina reke Bistre, $650 \mathrm{~m}$; dolina Tržiške Bistrice (Glowacki 1912); pod Javorniškim sedlom (za Storžičem), $800 \mathrm{~m}$.
Andreaea rupestris Hedw. - bor-mont: Javorniško sedlo (za Storžičem), 1400 m (Martinčič LJU 1962, Deschmann 1869, Dolšak LJU 1921).

Anomobryum concinnatum (Spruce) Lindb. bor-mont: dolina Tržiške Bistrice pri Tržiču, 700 m (Glowacki 1912, Suanjak 2002 leg. Glowacki).

Anomodon attenuatus (Hedw.) Hueb. - subtemp: nad Gozd Martuljkom, 800 m; nad Dovjem, 800 m; Begunjščica, 1000 m; dolina Završnica, 800 m; Vranček pod Ljubeljem, 850 m; Lajb pod Ljubeljem, $750 \mathrm{~m}$; Jelendol, pod Penatco, $900 \mathrm{~m}$; pod Pavličevim sedlom, pri kmetiji Covnik, 1200 m; Zgornji Razbor, 700 m; Beli potok pri Podljubelju (Glowacki 1912); Čadovlje pri Tržiču, $600 \mathrm{~m}$; Dolžanova soteska, pri vasi Dolina, $750 \mathrm{~m}$.

Anomodon longifolius (Schleich. ex Brid.) Hartm. - bor-temp: Belščica (Paulin 1914).

Anomodon rostratus (Hedw.) Schimp. - temp-subkont: Begunjščica, nad Poljško planino, $1500 \mathrm{~m}$ (Martinčič 2004); Begunjščica, $1000 \mathrm{~m}$.

Anomodon viticulosus (Hedw.) Hook \& Taylor bor-temp: nad Gozd Martuljkom, $800 \mathrm{~m}$; nad Dovjem, 800 m; dolina Završnica, 800 m; Košuta: planina Korošica (Wallnöfer 1888); nad Solčavo, levi breg nad reko Savinjo, $700 \mathrm{~m}$ (Grom LJU 1970); Uršlja gora, 1320 m (Grom LJU 1959); Dolžanova soteska, pri vasi Dolina, $750 \mathrm{~m}$.

Atrichum angustatum (Brid.) Bruch \& Schimp. - temp: Potoška planina pod Belščico, 1300 m; dolina Koprivna, 950 m; Olševa: Zadnji travnik, $1400 \mathrm{~m}$; dolina reke Bistre, $650 \mathrm{~m}$; pri Črni na Koroškem, proti Javorju, 650 m; Uršlja gora, $1400 \mathrm{~m}$.

Atrichum tenellum (Roehl.) Bruch \& Schimp. bor-temp: pod Pavličevim sedlom, pri kmetiji Covnik, 1200 m; Draga pri Begunjah na Gorenjskem (Martinčič 1976, Martinčič 2005).

Atrichum undulatum (Hedw.) P. Beauv. - bor-temp: Peč, pri planinskem domu Tromeja, $1200 \mathrm{~m}$; Sv. Križ pri Planini pod Golico, 1000 m; Krvavka, 1750 m; Hruški vrh, 1700 m; Medji dol nad Jesenicami (Müllner 1893); planina Pusti rovt pod Korenščico, 1500 m; Javorniški Rovt, 1100 m; Debelo brdo pod Belščico, 1200 m; pri Valvazorjevem domu, pod Stolom, 1300 m; Begunjščica, 1000 m; dolina Završnica, 800 m; Zgornje Jezersko: pod Roblekom, 1000 m; dolina Koprivna, 950 m; Strevčev vrh pri Olševi, nad Rogarjem, 1400 m; dolina reke Bistre, 650 m; Draga pri Begunjah na Gorenj- 
skem, 690 m (Piskernik 1977, det. Martinčič); Javorniško sedlo (za Storžičem), 1400 m.

Aulacomnium palustre (Hedw.) Schwaegr. - subbor: Olševa, sev. pobočje, 1300 m; Olševa: barje Zadnji travnik 1340 m (Piskernik \& Martinčič 1970); Plešivški mlin pod Uršljo goro, $900 \mathrm{~m}$.

Barbula convoluta Hedw. var. convoluta - ubikv: Javornik pri Jesenicah (Sendtner 1857); Peč, $1200 \mathrm{~m}$; pod Javornikom (za Storžičem), $800 \mathrm{~m}$.

Barbula crocea (Brid.) F. Weber \& D. Mohr temp: Medvedjek nad Podkorenom, $1000 \mathrm{~m}$; Rateče, 900 m; Srednji vrh nad Gozd Martuljkom, $1000 \mathrm{~m}$; dolina Belce, $860 \mathrm{~m}$ (Grom LJU 1965, leg. T. Wraber); dolina Završnica, Žingarica, $800 \mathrm{~m}$; Begunjščica, zah. pobočje, 1300 m; Ljubelj, 1000 m; pri Podpeci; Uršlja gora (Wallnöfer 1888); Podgorje pri Slovenj Gradcu, 450 m; Draga pri Begunjah na Gorenjskem, 690 m; pod Javorniškim sedlom (za Storžičem), $800 \mathrm{~m}$.

*Barbula unguiculata Hedw. - ubikv: nad Podkorenom, 950 m; nad Gozd Martuljkom, 800 m; med Gozd Martuljkom in Belco, $700 \mathrm{~m}$; nad Dovjem, $800 \mathrm{~m}$; Spodnje Jezersko: Tisovec, 850 m; Olševa: Zadnji travnik, 1400 m; Mala Peca, 1400 m; Dolžanova soteska, pri vasi Dolina, $750 \mathrm{~m}$.

Bartramia halleriana Hedw. - bor-mont: Medvedjek nad Podkorenom, 1000 m; Črni vrh nad Jesenicami, 1400 m; Klek, 1600 m; Medji dol nad Jesenicami (Müllner 1893); Potoška planina pod Belščico, $1300 \mathrm{~m}$; dolina Topla, nad Fajmutom, 1100 m; dolina Topla, pri Florinu, $900 \mathrm{~m}$; Jazbina nad Mežiško dolino (Grom LJU 1959); dolina reke Bistre pri Črni na Koroškem (Wallnöfer 1888); dolina reke Bistre, 650 m; Uršlja gora: Kozarnica, 1150 m (Grom LJU 1958); Podljubelj (Grom LJU 1963).

Bartramia ithyphylla Brid. - bor-mont: Peč, pri planinskem domu Tromeja, $1200 \mathrm{~m}$; Stol, 2000 m; Stol (Dolšak LJU 1920); dolina reke Bistre pri Črni na Koroškem (Wallnöfer 1888).

Bartramia pomiformis Hedw. - bor-temp: Medji dol (Müllner 1893, Plemelj V. LJU 1873); Javorniški Rovt, 1100 m; Debelo brdo pod Belščico, 1200 m; Koroška Bela (Plemelj V. LJU 1873); Zelenica (Müllner 1893); dolina Koprivna, $950 \mathrm{~m}$; dolina Topla, pod Burjakovim hribom, 700 m; Strevčev vrh pri Olševi, nad Rogarjem, 1400 m; Uršlja gora: Kozarnica, 1000 m (Piskernik 1977, det. Martinčič); Orlovec pri planini Podstoržič.
Blindia acuta (Hedw.) Bruch \& Schimp. - bor-mont: dolina Koprivna: Sv. Jakob (Glowacki 1908); dolina reke Bistre, $650 \mathrm{~m}$.

var. seligeri (Brid.) Limpr.: dolina Koprivna: Sv. Jakob (Glowacki 1908).

*DD-Brachytheciastrum olympicum (Jur.) Vanderp. et al. - subatl-submed: Peč, 1100 m.

Brachytheciastrum velutinum (Hedw.) Ignatov \& Huttunen - temp: Medvedjek nad Podkorenom, $1000 \mathrm{~m}$; Korensko sedlo, $1060 \mathrm{~m}$; Peč, pri planinskem domu Tromeja, $1200 \mathrm{~m}$; Klek, 1000 m; Sv. Križ pri Planini pod Golico, 1000 m; Krvavka, 1750 m; planina Pusti rovt pod Korenščico, 1500 m; Medji dol, 1000 m; Belščica (Paulin 1914); Gozdašnica, nad dolino Završnico, $800 \mathrm{~m}$; Potoška planina pod Belščico, 1300 m; Begunjščica, 1200 m, 2000 m; dolina Završnica, 900 m; Stol, 1600 m; dolina Završnica, pod Begunjščico, 1000 m; Vranček pod Ljubeljem, $850 \mathrm{~m}$; pod Pavličevim sedlom, pri kmetiji Covnik, 1200 m; Olševa, sev. pobočje, 1300 m; Olševa, 1400 m (Kutnar et al. 2006, det. Martinčič); Olševa: Zadnji travnik, $1400 \mathrm{~m}$; dolina Koprivna, 1200 m; dolina Topla, pod Peco; Najbrževo pod Malo Peco, 1400 m (Kutnar et al. 2006, det. Martinčič); dolina Topla, nad Fajmutom, 1100 m; Olševa (Breidler 1891); Olševa, juž. pobočje, $800 \mathrm{~m}$; Strevčev vrh pri Olševi, nad Rogarjem, 1400 m; Sv. Duh pod Olševo, $1200 \mathrm{~m}$; dolina reke Bistre, $650 \mathrm{~m}$; Uršlja gora, 1300 m (Piskernik 1977, det. Martinčič); Uršlja gora, 1320 m (Grom LJU 1957); Plešivški mlin pod Uršljo goro, $900 \mathrm{~m}$; Bačovski vrh, 1000 m; Zgornji Razbor, 700 m; Spodnji Razbor pri Mislinjski Dobravi, 500 m; Podljubelj, 1300 m; Stolec nad Tržičem, 560 m; Javorniško sedlo (za Storžičem), $1400 \mathrm{~m}$.

Brachythecium campestre (Müll.Hal.) Schimp. - temp-subkont: Srednji vrh nad Gozd Martuljkom, 950 m; med Gozd Martuljkom in Belco, 700 m; Vranček pod Ljubeljem, 850 m; Jelendol, pod Penatco, 900 m; Medvodje pod Penatco, $850 \mathrm{~m}$; Spodnje Jezersko: Tisovec, $850 \mathrm{~m}$; Sv. Duh nad Solčavo (Breidler 1891); dolina Koprivna, 1300 m; dolina Topla, 750 m; Spodnji Razbor pri Mislinjski Dobravi, 500 m; dolina Tržiške Bistrice (Glowacki 1912); Čadovlje pri Tržiču, $600 \mathrm{~m}$.

Brachythecium cirrosum (Schwaegr.) Schimp. arkt-alp: Hruški vrh, 1700 m; Struška Kočna, 1600 m; Vajnež, 2000 m; Stol, 2000 m; Begunjščica, vrh, $2000 \mathrm{~m}$ (Martinčič 2009); Olševa (Breidler 1891); Uršlja gora, $1500 \mathrm{~m}$. 
*NT-Brachythecium geheebii Milde - temp-subkont: Korensko sedlo, $1060 \mathrm{~m}$; Medji dol, 1000 m; Korenščica, 1500 m; Spodnje Jezersko: Tisovec, 850 m; dolina Koprivna, 1300 m.

*Brachythecium glareosum (Bruch ex Spruce) Schimp. - bor-temp: Rateče, 900 m; Vajnež, 2100 m; Begunjščica, 1000 m; Jelendol, 900 m; pod Pavličevim sedlom, pri kmetiji Covnik, 1200 m; Olševa: Zadnji travnik, 1400 m; dolina Koprivna, $950 \mathrm{~m}$; dolina Topla, $800 \mathrm{~m}$; dolina reke Bistre, $650 \mathrm{~m}$; Bačovski vrh, $1000 \mathrm{~m}$.

*Brachythecium laetum (Brid.) Schimp. - temp-subkont: Hruški vrh, $1700 \mathrm{~m}$.

*Brachythecium mildeanum (Schimp.) Schimp. - temp: pod Pavličevim sedlom, pri kmetiji Covnik, 1200 m; dolina Topla, nad Fajmutom, 1100 m; Strevčev vrh pri Olševi, nad Rogarjem, $1400 \mathrm{~m}$.

Brachythecium rivulare Schimp. - bor-temp: Peč, pri planinskem domu Tromeja, $1200 \mathrm{~m}$; Srednji vrh nad Gozd Martuljkom, 1000 m; Sv. Križ pri Planini pod Golico, 1000 m; Črni vrh nad Jesenicami, 1400 m; Hruška planina pod Rožco, $1200 \mathrm{~m}$; planina Pusti rovt pod Korenščico, 1500 m; Medji dol, 1000 m; dolina Završnica, $800 \mathrm{~m}$; v potoku Mošenik pri Podljubelju, $700 \mathrm{~m}$; Lajb pod Ljubeljem, $750 \mathrm{~m}$; pod Pavličevim sedlom, pri kmetiji Covnik, 1200 m; dolina Koprivna, 1300 m; Strevčev vrh pri Olševi, nad Rogarjem, 1400 m; Zgornji Razbor, 700 m; Čadovlje pri Tržiču, $600 \mathrm{~m}$.

*Brachythecium rutabulum (Hedw.) Schimp. - temp: Peč, 1100 m; nad Gozd Martuljkom, 800 m; Krvavka, 1400 m; Hruška planina pod Rožco, 1200 m; Velika Golica, 1400 m; planina Pusti rovt pod Korenščico, 1500 m; Medji dol, $1000 \mathrm{~m}$; Debelo brdo pod Belščico, $1200 \mathrm{~m}$; Gozdašnica, nad dolino Završnico, 800 m; Potoška planina pod Belščico, $1300 \mathrm{~m}$; dolina Završnica: Žingarica, 800 m; Begunjščica, 1000 m; Ljubelj: Sv. Ana, 900 m; Vranček pod Ljubeljem, 850 m; Lajb pod Ljubeljem, 750 m; Jelendol, 900 m; Spodnje Jezersko: Tisovec, $850 \mathrm{~m}$; Zgornje Jezersko: pod Roblekom, 1000 m; pod Pavličevim sedlom, pri kmetiji Covnik, 1200 m; Olševa: Zadnji travnik, 1400 m; dolina Topla, pod Burjakovim hribom, 700 m; dolina reke Bistre, 650 m; pri Črni na Koroškem, proti Javorju, 650 m; dolina Koprivna, 900 m; Uršlja gora: pri kmetiji Plešivec, 950 m; Uršlja gora, 1400 m; Zgornji Razbor, 700 m; Spodnji Razbor pri Mislinjski Dobravi, 500 m; Draga pri Begunjah na Gorenjskem, 690 m; Smokuč pri
Begunjah na Gorenjskem, 540 m; Čadovlje pri Tržiču, $600 \mathrm{~m}$.

Brachythecium salebrosum (Hoffm. ex F. Weber \& D. Mohr) Schimp. - subbor: Peč, pri planinskem domu Tromeja, 1200 m; Hruška planina pod Rožco, 1200 m; med Gozd Martuljkom in Belco, 700 m; nad Dovjem, 850 m; Sv. Križ pri Planini pod Golico, $1000 \mathrm{~m}$; Uršlja gora, 1000 m; Begunjščica, 2000 m; Olševa: Zadnji travnik, $1400 \mathrm{~m}$; dolina Topla, pod Burjakovim vrhom, $700 \mathrm{~m}$; dolina Topla, nad Fajmutom, $1100 \mathrm{~m}$; dolina reke Bistre, $650 \mathrm{~m}$; Uršlja gora: pod Kotartkovim vrhom, 1040 m, (Grom LJU 1957 det. Martinčič, Martinčič 2009); Strevčev vrh pri Olševi, nad Rogarjem, 1400 m; Bačovski vrh, 1100 m (Martinčič 2012); Čadovlje pri Tržiču, $600 \mathrm{~m}$.

*Brachythecium tommasinii (Sendtn. ex Boul.) Ignatov \& Huttunen - temp-subkont: nad Dovjem, 800 m; dolina Završnica, 800 m; Dolžanova soteska, pri vasi Dolina, $750 \mathrm{~m}$.

Bryoerythrophyllum recurvirostrum (Hedw.) $\mathrm{P}$. C. Chen - bor-temp: nad Podkorenom, 950 m; nad Gozd Martuljkom, $800 \mathrm{~m}$; Hruški vrh, 1700 m; Klek, 1600 m; Krvavka, 1750 m; Velika Golica, 1400 m; Sv. Križ pri Planini pod Golico, 1000 m; Struška Kočna 1600 m; Vajnež, 2100 m; Korenščica, 1500 m; med Javornikom (Jesenice) in Javorniškim Rovtom, $800 \mathrm{~m}$; Debelo brdo pod Belščico, $1200 \mathrm{~m}$; pri Valvazorjevem domu pod Stolom, 1200 m; Stol, 1600 m; Mali Stol (Paulin 1914); Begunjščica, vrh, 2000 m; Begunjščica, nad Poljško planino, 1500 m; pod Ljubeljem, 950 m; Spodnje Jezersko: Tisovec, $850 \mathrm{~m}$; dolina Topla, nad Fajmutom, $1100 \mathrm{~m}$; dolina reke Bistre, $650 \mathrm{~m}$; Plešivški mlin pod Uršljo goro, $900 \mathrm{~m}$; Uršlja gora, 1500 m; Čadovlje pri Tržiču, $600 \mathrm{~m}$.

*Bryum archangelicum Bruch \& Schimp. - temp: Hruški vrh, 1700 m; Vajnež, 2100 m; Stol, $2000 \mathrm{~m}$.

Bryum argenteum Hedw. - ubikv: Peč, pri planinskem domu Tromeja, $1200 \mathrm{~m}$; nad Podkorenom, $950 \mathrm{~m}$; med Gozd Martuljkom in Belco, $700 \mathrm{~m}$; Srednji vrh nad Gozd Martuljkom, 1000 m; Krvavka, 1700 m; Olševa: Zadnji travnik, 1400 m; Strevčev vrh pri Olševi, nad Rogarjem, 1400 m; Olševa: Potočka zijalka, vhod, 1700 m; Mala Peca, 1400 m; dolina Tržiške Bistrice (Glowacki 1912).

*Bryum caespiticium Hedw. - ubikv: med Gozd Martuljkom in Belco, $700 \mathrm{~m}$; Potoška planina pod Belščico, 1300 m; Vranček pod Ljubeljem, 
850 m; Ljubelj: Sv. Ana, 900 m; pod Pavličevim sedlom, pri kmetiji Covnik, $1200 \mathrm{~m}$.

Bryum capillare Hedw. - ubikv: Peč, pri planinskem domu Tromeja, 1200 m; Medvedjek nad Podkorenom, 1000 m; Korensko sedlo, 1060 m; nad Podkorenom, 950 m; med Gozd Martuljkom in Belco, 700 m; nad Dovjem, 800 m; Sv. Križ pri Planini pod Golico, 1000 m; Klek, 1600 m; Velika Golica, 1400 m; Hruška planina pod Rožco, 1200 m; Potoška planina pod Belščico, 1300 m; Debelo Brdo pod Belščico, 1200 m; med Javornikom (Jesenice) in Javorniškim Rovtom, 800 m; dolina Završnica, 800 m; Stol, 1200 m; Spodnje Jezersko: Tisovec, 850 m; pod Pavličevim sedlom, pri kmetiji Covnik, 1200 m; dolina Koprivna, 1200 m; dolina Topla, pod Burjakovim hribom, 700 m; Strevčev vrh pri Olševi, nad Rogarjem, 1400 m; Uršlja gora: Ravensko, 1130 m (leg. Piskernik); Uršlja gora, 1600 m; Uršlja gora: pri kmetiji Plešivec, 950 m; Bačovski vrh, $1000 \mathrm{~m}$; Čadovlje pri Tržiču, $600 \mathrm{~m}$.

*Bryum creberrimum Taylor - bor-temp: Medvedjek nad Podkorenom, $1000 \mathrm{~m}$.

*Bryum dichotomum Hedw. - ubikv: Krvavka, $1750 \mathrm{~m}$.

Bryum elegans Nees - bor-mont: Begunjščica, vrh, 2000 m; dolina Tržiške Bistrice (Glowacki 1912).

*Bryum intermedium (Brid.)Blandow - subbor: Vajnež, 2000 m; Čadovlje pri Tržiču, 600 m.

Bryum mildeanum Jur. - subbor: dolina Tržiške Bistrice (Glowacki 1912).

DD-Bryum muehlenbeckii Bruch \& Schimp. bor-mont: Belščica (Paulin 1914).

Bryum pallens Sw. ex anon. - subbor: Medvedjek nad Podkorenom, 1000 m; Srednji vrh nad Gozd Martuljkom, 950 m; nad Dovjem, 800 m; Sv. Duh pod Olševo, pri Potočniku, $1200 \mathrm{~m}$; dolina Topla, pod Burjakovim hribom, 700 m; Uršlja gora, $1500 \mathrm{~m}$; Uršlja gora: Ravensko, 1050 m; Javorniško sedlo (za Storžičem), 1400 m; pod Javorniškim sedlom (za Storžičem), 800 m; dolina Tržiške Bistrice (Glowacki 1912).

*Bryum pallescens Schleich. ex Schwaegr. ubikv: Krvavka, 1300 m; Potoška planina pod Belščico, 1300 m.

Bryum pseudotriquetrum (Hedw.) P. Gaertn. et al. - ubikv: Kot pri Prevaljah (Zelnik et al. 2010); Raduša: Smrčun (Zelnik et al. 2010); Sele: Blatnik (Zelnik et al. 2010); Hruška planina, pod Rožco, 1200 m; Črni vrh nad Jesenicami,
1400 m; Medji dol (Wallnöfer 1888, Müllner 1893); Medji dol, 1000 m; Vajnež, 2100 m; Potoška planina pod Belščico, $1300 \mathrm{~m}$; dolina Završnica nad Žirovnico (Müllner 1893); Zelenica (Plemelj V. LJU 1873); Begunjščica, 1200 m; Zgornje Jezersko: pod Roblekom, 1000 m; pod Pavličevim sedlom, pri kmetiji Covnik, 1200 m; dolina Koprivna, $1200 \mathrm{~m}$.

Bryum rubens Mitt. - temp: dolina Tržiške Bistrice (Glowacki 1912).

Buxbaumia aphylla Hedw. - bor-mont: Črni vrh nad Jesenicami, $1400 \mathrm{~m}$;

NT-Buxbaumia viridis (Moug. ex Lam. \& DC.) Brid. ex Moug. \& Nestl. - bor-mont: Medji dol (Matouschek 1901, Müllner 1893); nad Javornikom pri Jesenicah (Plemelj V. LJU 1873); pri Valvazorjevem domu pod Stolom, $1200 \mathrm{~m}$; Zelenica (Müllner 1893, Deschmann 1862).

*Callicladium haldanianum (Grev.) H. A. Crum - temp-subkont: Uršlja gora, $1650 \mathrm{~m}$.

Calliergon cordifolium (Hedw.) Kindb. - bor-temp: pod Pavličevim sedlom, pri kmetiji Covnik, 1150 m (Martinčič 2005); Olševa: Zadnji travnik, $1400 \mathrm{~m}$.

*NT-Calliergon giganteum (Schimp.) Kindb. bor-mont: Olševa: Zadnji travnik, $1400 \mathrm{~m}$.

Calliergonella cuspidata (Hedw.) Loeske - temp: Peč, 1250 m; nad Dovjem, 800 m; Črni vrh nad Jesenicami, 1400 m (Martinčič 2004); med Hruško planino in Sv. Križem pri Planini pod Golico, 1100 m; Velika Golica, 1400 m; Potoška planina pod Belščico, $1300 \mathrm{~m}$; Javorniški Rovt, 1100 m; Ljubelj: Sv. Ana, 900 m; Jelendol; Zgornje Jezersko: pod Roblekom, 1000 m; pod Pavličevim sedlom, blizu kmetije Covnik, 1150 m; Olševa: Zadnji travnik, 1400 m; Strevčev vrh pri Olševi, nad Rogarjem, 1400 m; Plešivški mlin pod Uršljo goro, $900 \mathrm{~m}$; Draga pri Begunjah na Gorenjskem, $690 \mathrm{~m}$.

Calliergonella lindbergii (Mitt.) Hedenäs - subbor: Potoška planina pod Belščico, $1300 \mathrm{~m}$; Uršlja gora (Wallnöfer 1888); med Hruško planino in Sv. Križem pri Planini pod Golico, $1400 \mathrm{~m}$.

Campyliadelphus chrysophyllus (Brid.) R.S. Chopra - ubikv: Peč, pod planinskim domom Tromeja, 1200 m; nad Ratečami, 1000 m; Uršlja gora: pobočje nad Ravnami (Glowacki 1908); nad Gozd Martuljkom, 800 m; Klek, 1600 m; Struška Kočna, 1600 m; Vajnež, 2100 m; dolina Završnica, $800 \mathrm{~m}$; Vranček pod Ljubeljem, $850 \mathrm{~m}$; Medvodje pod Penatco, $850 \mathrm{~m}$; Jelendol, pod Penatco, $900 \mathrm{~m}$; dolina reke Bistre, 650 m; Zgornji Razbor, 700 m; Draga pri Be- 
gunjah na Gorenjskem, 690 m; Beli potok pri Podljubelju (Glowacki 1912).

*Campyliadelphus elodes (Lindb.) Kanda - temp: Srednji vrh nad Gozd Martuljkom, 1000 m; nad Gozd Martuljkom, 1300 m; Hruška planina pod Rožco, 1200 m; Struška Kočna, 1600 m; pri Valvazorjevem domu, pod Stolom, 1200 m; Stol, 2000 m; Ljubelj, 1000 m; Vranček pod Ljubeljem, 850 m; Jelendol, pod Penatco, 900 m; Medvodje pod Penatco, 850 m; Podgorje pri Slovenj Gradcu, $450 \mathrm{~m}$.

Campylium protensum (Brid.) Kindb. - bor-temp: nad Ratečami, 1000 m; nad Dovjem, 850 m; C̆rni vrh nad Jesenicami, 1400 m; Hruška planina pod Rožco, 1200 m; Krvavka, 1300 m; pod Pavličevim sedlom, pri kmetiji Covnik, $1200 \mathrm{~m}$; Javorniški Rovt, 1100 m; Medji dol, 1000 m; pri Valvazorjevem domu pod Stolom, 1200 m; pod Ljubeljem, $950 \mathrm{~m}$; Medvodje pod Penatco, 850 m; Spodnje Jezersko: Tisovec, 850 m; Zgornje Jezersko: pod Roblekom, 1000 m; Olševa: Zadnji travnik. $1400 \mathrm{~m}$; Olševa: barje Zadnji travnik, 1340 m; dolina Topla, nad Fajmutom, 1100 m; Sv. Duh pod Olševo, pri Potočniku, 1200 m; Zgornji Razbor, 700 m; Podgorje pri Slovenj Gradcu, 450 m; Draga pri Begunjah na Gorenjskem, 690 m;

Campylium stellatum (Hedw.) Lange \& C. E. O. Jens. - bor-temp: Peč, $1250 \mathrm{~m}$; Srednji vrh nad Gozd Martuljkom, 1000 m; nad Dovjem, 850 m; Klek, 1600 m; Krvavka, 1500 m; Velika Golica, 1400 m; Črni vrh nad Jesenicami, 1400 m; Hruška planina pod Rožco, 1200 m; Sv. Križ pri Planini pod Golico, 1000 m; Struška Kočna, 1600 m; Javorniški Rovt, 1200 m; Korenščica, 1500 m, 1700 m; Debelo brdo pod Belščico, 1200 m; Vajnež, 2100 m; med Javornikom (Jesenice) in Javorniškim Rovtom, 800 m; Begunjščica, $1000 \mathrm{~m}$; pri Valvazorjevem domu pod Stolom, 1200 m; Stol, 2000 m; nad planino Vrtačo, 1400 m; Vranček pod Ljubeljem, 850 m; Zgornje Jezersko: pod Roblekom, 1000 m; pod Pavličevim sedlom, pri kmetiji Covnik, 1200 m; dolina Topla, pri Florinu, 900 m; Strevčev vrh pri Olševi, nad Rogarjem, 1400 m; Uršlja gora, 1600 m; Zgornji Razbor, 700 m; Podgorje pri Slovenj Gradcu, 450 m; med Smokučem in Rodinami, 550 m (Martinčič 2009).

*Campylophyllum calcareum (Crundw. \& Nyholm) Hedenäs - temp: nad Dovjem, 800 m.

Campyllophyllum halleri (Hedw.) Fleisch. - bor-mont: Krvavka, 1500 m; Velika Golica, 1400 m; Korenščica, 1500 m; Medji dol, 1000 m; Stru- ška Kočna, 1600 m; Belščica (Paulin 1914); planina Pusti rovt pod Korenščico, 1500 m; Vajnež, $2100 \mathrm{~m}$; pri Valvazorjevem domu pod Stolom, 1200 m; Stol, 2000 m; nad planino Vrtačo, 1400 m; Begunjščica, 1000 m, 2000 m; Olševa, sev. pobočje, $1300 \mathrm{~m}$; Uršlja gora, $1600 \mathrm{~m}$; Dolžanova soteska, $600 \mathrm{~m}$; pod Javorniškim sedlom (za Storžičem), $800 \mathrm{~m}$.

Campylophyllum sommerfeltii (Myr.) Hedenäs bor-temp: Uršlja gora, pobočje proti Ravnam (Glowacki 1908); grad Kamen pri Begunjah na Gorenjskem (Glowacki 1912); dolina Tržiške Bistrice (Glowacki 1912); Uršlja gora: graben Suhe (Glowacki 1908) ;

Campylopus flexuosus (Hedw.) Brid. - temp-suba$t l$ : Javorniški Rovt, $1100 \mathrm{~m}$.

*Campylopus subulatus Schimp. ex Milde - temp-subatl: dolina Završnica, $800 \mathrm{~m}$.

Ceratodon purpureus (Hedw.) Brid. - ubikv: Peč, pri planinskem domu Tromeja, $1200 \mathrm{~m}$; Korensko sedlo, 1080 m; Krvavka, 1750 m; C̆rni vrh nad Jesenicami, 1400 m; Velika Golica, 1400 m; Medji dol, $1000 \mathrm{~m}$; Begunjščica (Merčun LJU 1929); Begunjščica, nad Poljško planino, 1500 m; Ljubelj: Sv. Ana, 900 m; pod Pavličevim sedlom, pri kmetiji Covnik, 1200 m; Olševa: Zadnji travnik, 1400 m; Strevčev vrh pri Olševi, nad Rogarjem, 1400 m; Spodnji Razbor pri Mislinjski Dobravi, 500 m; Smokuč pri Begunjah na Gorenjskem, 540 m; Čadovlje pri Tržiču, 600 m; Stolec nad Tržičem, 560 m; pod Javorniškim sedlom (za Storžičem, 800 m.

Cinclidotus aquaticus (Hedw.) Bruch \& Schimp. - temp: Medji dol, 1000 m; Javornik pri Jesenicah (Müllner 1893); v potoku Mošenik pri Tržiču; Spodnje Jezersko: v reki Kokri.

Cirriphyllum crassinervium (Taylor) Loeske \& M. Fleisch. - temp: Srednji vrh nad Martuljkom, $950 \mathrm{~m}$; nad Dovjem, $800 \mathrm{~m}$; dolina Završnica, 800 m; Begunjščica, 2000 m (L-2012); dolina Koprivna, ob reki Koprivni, 900 m; Zgornji Razbor, 700 m; dolina Tržiške Bistrice (Glowacki 1912).

Cirriphyllum piliferum (Hedw.) Grout - bor-temp: Begunjščica, zah. pobočje, 1300 m (Martinčič 2009); dolina Koprivna, ob reki Koprivni, 900 m; Olševa: Zadnji travnik, 1400 m; Klipovčnik v dolini Bistre (Wallnöfer 1888); Uršlja gora, $1500 \mathrm{~m}$.

Climacium dendroides (Hedw.) F. Weber \& D. Mohr - subbor: Peč, pri planinskem domu Tromeja, $1200 \mathrm{~m}$; planina Pusti rovt pod Korenščico, $1500 \mathrm{~m}$; Potoška planina pod Belščico, 
1300 m (Martinčič 2004); Javornik pri Jesenicah (Plemelj LJU 1873); Stol; Begunjščica (L-2004); Ljubelj: Sv. Ana, 900 m; Spodnje Jezersko: Tisovec, $850 \mathrm{~m}$; Zgornje Jezersko: pod Roblekom, 1000 m; Olševa: Zadnji travnik, 1400 m; dolina Topla, nad Fajmutom, 1100 m.

Cratoneuron curvicaule (Jur.) G. Roth - subarkt-subalp: Olševa (Breidler 1891).

Cratoneuron filicinum (Hedw.) Spruce - ubikv: nad Podkorenom, 950 m; Srednji vrh nad Gozd Martuljkom, 1000 m; nad Gozd Martuljkom, 800 m; nad Dovjem, 850 m; Sv. Križ pri Planini pod Golico, 1000 m; Velika Golica, 1400 m; Krvavka; Medji dol, 1000 m; planina Pusti rovt pod Korenščico, 1500 m; Vajnež, 2100 m (Martinčič 2004); Javorniški Rovt, 1100 m; Potoška planina pod Belščico, $1300 \mathrm{~m}$; dolina Završnica: Žingarica, $800 \mathrm{~m}$; dolina Završnica, $800 \mathrm{~m}$; Ljubelj: Sv. Ana, $900 \mathrm{~m}$ (Martinčič 2004); v potoku Mošenik pri Podljubelju, 700 m; Lajb pod Ljubeljem, $750 \mathrm{~m}$; Vranček pod Ljubeljem, $850 \mathrm{~m}$; pod Pavličevim sedlom, pri kmetiji Covnik, 1200 m; dolina Koprivna, 1200 m; dolina Topla, nad Fajmutom, 1100 m; Strevčev vrh pri Olševi, pod Rogarjem, 1400 m; Olševa: Potočka zijalka, vhod, $1700 \mathrm{~m}$; Črna na Koroškem (Wallnöfer 1888); Uršlja gora (Wallnöfer 1888); Čadovlje pri Tržiču $600 \mathrm{~m}$.

var. atrovirens (Brid.) Ochyra: Hruška planina pod Rožco, 1200 m; dolina Završnica, pod Begunjščico,800 m (Martinčič 2004).

Ctenidium molluscum (Hedw.) Mitt. - bor-temp: Peč, pri planinskem domu Tromeja, $1200 \mathrm{~m}$; Uršlja gora: pobočje nad Ravnami (Glowacki 1908); Podkoren (Piskernik 1977, det. Martinčič); Srednji vrh nad Gozd Martuljkom, 1000 m; nad Gozd Martuljkom, 800 m; Dovška Baba, 1800 m; Črni vrh nad Jesenicami, 1400 m (Piskernik 1977, det. Martinčič); Klek, 1600 m; Sv. Križ pri Planini pod Golico, $1000 \mathrm{~m}$; Krvavka, $1750 \mathrm{~m}$; Velika Golica, $1400 \mathrm{~m}$; Hruški vrh, 1700 m; Javorniški Rovt, 1100 m; Medji dol, 1000 m; Belščica (Paulin 1914); Potoška planina pod Belščico, 1300 m; Vajnež, 2100 m; dolina Završnica, 800 m; Begunjščica, 2000 m; Begunjščica (Piskernik 1971, det. Martinčič); pri Valvazorjevem domu pod Stolom, 1200 m; Košuta: planina Kofce (Piskernik 1977, det. Martinčič); Vranček pod Ljubeljem, $850 \mathrm{~m}$; Jelendol, pod Penatco, 900 m; Jelendol, 1350 m (Marinček \& Čarni 2007); Jelendol nad Tržičem (Grom LJU 1959); Spodnje Jezersko: Tisovec, 850 m; Jezersko: med Roblekom in Vršni- kom, 970 m (Marinček \& Čarni 2007); pod Pavličevim sedlom, pri kmetiji Covnik, $1200 \mathrm{~m}$; Olševa, sev. pobočje, $1300 \mathrm{~m}$; Olševa, $1400 \mathrm{~m}$ (Kutnar et al. 2006, det. Martinčič); Olševa: Zadnji travnik, 1400 m; Olševa: pri Potočki zijalki, 1600 m (Grom LJU 1970); dolina Koprivna, 950 m; Peca, 1300 m (Piskernik 1977, det. Martinčič); Javorje pod Malo Peco, $1320 \mathrm{~m}$ (Kutnar et al. 2006, det. Martinčič); Najbrževo pod Malo Peco, 1400 m (Kutnar et al. 2006, det. Martinčič); dolina Topla, nad Fajmutom, 1100 m; nad Solčavo, levi breg Savinje, 700 m (Grom LJU 1970); Strevčev vrh pri Olševi, nad Rogarjem, $1400 \mathrm{~m}$; Jazbina pri Žerjavu, $700 \mathrm{~m}$ (Piskernik 1977, det. Martinčič); Črna na Koroškem, breg reke Bistre, 620 m (Juvan 2008); Ludranski vrh, $1020 \mathrm{~m}$; Uršlja gora, $1000 \mathrm{~m}$ (Piskernik 1977, det. Martinčič); Uršlja gora: Kozarnica, 1000 m (Piskernik 1977, det. Martinčič); Uršlja gora, $1600 \mathrm{~m}$; pod Uršljo goro, 1190 m (Marinček \& Čarni 2007); Završe nad Mislinjo (Piskernik 1977, det. Martinčič); med Smokučem in Rodinami, 550 m; Draga pri Begunjah na Gorenjskem, 690 m; Sv. Peter nad Begunjami na Gorenjskem, $700 \mathrm{~m}$ (Piskernik 1977, det. Martinčič); Podljubelj, $1000 \mathrm{~m}$ (Grom LJU 1963); Čadovlje pri Tržiču, 600 m; Dolžanova soteska, pri vasi Dolina, $750 \mathrm{~m}$; Javorniško sedlo (za Storžičem), $1400 \mathrm{~m}$; Stegovnik (Piskernik 1977, det. Martinčič).

*EN-Cynodontium fallax Limpr. - bor-mont: dolina reke Bistre, $650 \mathrm{~m}$; Uršlja gora, $1500 \mathrm{~m}$.

Cynodontium polycarpon (Hedw.) Schimp. - bor-mont: Medji dol (Müllner 1893); dolina Koprivna, $950 \mathrm{~m}$; dolina Topla, pod Burjakovim hribom, $700 \mathrm{~m}$; dolina Topla, pod Florinom, $850 \mathrm{~m}$.

Cynodontium strumiferum (Hedw.) Lindb. bor-mont: Krvavka, 1750 m (Martinčič 2009); Vajnež, 2100 m; dolina Topla, nad Fajmutom, 1400 m; Uršlja gora, 1500 m.

Cyrtomnium hymenophylloides (Hueben.) T.J. Kop. - subarkt-subalp: Vajnež, $2100 \mathrm{~m}$.

NT-Dichodontium palustre (Dicks.) M. Stech - bor-mont: Sv. Križ pri Planini pod Golico; Zgornje Jezersko: pod Roblekom, $1000 \mathrm{~m}$.

Dichodontium pellucidum (Hedw.) Schimp. bor-mont: Srednji vrh nad Gozd Martuljkom, 1000 m; Begunjščica, 1000 m; Spodnje Jezersko: Tisovec, 850 m; dolina Koprivna, 900 m; Olševa: Potočka zijalka, vhod, $1700 \mathrm{~m}$.

Dicranella cerviculata (Hedw.) Schimp. - bor-mont: Sv. Križ pri Planini pod Golico, 1000 m. 
*EN-Dicranella crispa (Hedw.) Schimp. - bor-mont: Olševa: Zadnji travnik, $1400 \mathrm{~m}$.

Dicranella heteromala (Hedw.) Schimp. - bor-temp: Peč, pri planinskem domu Tromeja, 1200 m; Črni vrh nad Jesenicami, 1400 m; Javorniški Rovt, 1100 m; Debelo brdo pod Belščico, $1200 \mathrm{~m}$; pri Valvazorjevem domu pod Stolom, 1200 m; Begunjščica, 1000 m; Spodnje Jezersko: Tisovec, $850 \mathrm{~m}$; Zgornje Jezersko: pod Roblekom, $1000 \mathrm{~m}$; pod Pavličevim sedlom, pri kmetiji Covnik, 1200 m; dolina Koprivna (Wraber 1963); dolina Koprivna, 950 m; dolina Topla, nad Fajmutom, $1400 \mathrm{~m}$; dolina Topla, pod Florinom, 850 m; Strevčev vrh pri Olševi, nad Rogarjem, 1400 m; pri Črni na Koroškem, proti Javorju, $650 \mathrm{~m}$; Šumahovo nad Črno na Koroškem (Piskernik 1977, det. Martinčič); dolina reke Bistre, 950 m; Bačovski vrh, 1000 m; Zgornji Razbor, $700 \mathrm{~m}$.

*Dicranella schreberiana (Hedw.) Dixon - bor-temp: Sv. Križ pri Planini pod Golico, 1000 m.

Dicranella varia (Hedw.) Schimp. - ubikv: Medji dol nad Jesenicami (Müllner 1893); Debelo brdo, pod Belščico, 1200 m; Spodnje Jezersko: Tisovec, $850 \mathrm{~m}$; Uršlja gora, $1600 \mathrm{~m}$.

Dicranodontium denudatum (Brid.) E. Britton bor-mont: dolina Topla, pod Florinom, $800 \mathrm{~m}$ (Martinčič 2012); pri Črni na Koroškem, proti Javorju, $650 \mathrm{~m}$.

Dicranoweisia crispula (Hedw.) Milde. - bor-mont: Beli potok pri Podljubelju (Glowacki 1912).

Dicranum bonjeanii De Not. - bor-temp: Medji dol (Müllner 1893); dolina Koprivna, $1000 \mathrm{~m}$ (Piskernik 1977, det. Martinčič); Olševa: barje Zadnji travnik, 1340 m (Martinčič 2012).

Dicranum fuscescens Sm. - bor-mont: pod Pavličevim sedlom, pri kmetiji Covnik, $1200 \mathrm{~m}$.

Dicranum majus Sm. - bor-temp: dolina Koprivna (Piskernik 1977, det. Martinčič); Olševa, juž. pobočje, $800 \mathrm{~m}$; Uršlja gora, $1300 \mathrm{~m}$ (Piskernik 1977, det. Martinčič).

Dicranum montanum Hedw. - bor-temp: nad Gozd Martuljkom, $800 \mathrm{~m}$; Mozganov vrh, 590 m (Piskernik 1977, det. Martinčič); dolina Koprivna, $950 \mathrm{~m}$; Javorje pod Malo Peco, $1320 \mathrm{~m}$ (Kutnar et al. 2006, det. Martinčič); Čofatijev vrh (Piskernik 1977, det. Martinčič); dolina Topla, nad Fajmutom, 1400 m; Bačovski vrh, $1000 \mathrm{~m}$.

*Dicranum muehlenbeckii Bruch \& Schimp. bor-mont: Olševa: barje Zadnji travnik, $1340 \mathrm{~m}$.

Dicranum polysetum Sw. ex anon. - bor-mont:
Peč, pri planinskem domu Tromeja, $1200 \mathrm{~m}$; Petelinjek nad Korenskim sedlom, 1425 m (leg. M. Zupančič); Medvedjek nad Podkorenom, 1000 m; Velika Golica, 1400 m; Korenščica, 1500 m; Begunjščica, 1000 m; Olševa: barje Zadnji travnik, 1340 m (Piskernik \& Martinčič 1970); Huda peč nad Solčavo, $1200 \mathrm{~m}$ (leg. Zupančič); Graška gora nad Velenjem (Grom LJU 1965);

Dicranum scoparium Hedw. - subbor: med Gozd Martuljkom in Belco, 700 m; Kališe pri Dovjem (Piskernik 1977, det. Martinčič); Črni vrh nad Jesenicami, 1400 m; Krvavka; Sv. Križ pri Planini pod Golico, $1000 \mathrm{~m}$; Velika Golica, 1400 m; Korenščica, 1500 m; Pristava pri Javorniku (Fr. Plemelj LJU 1848); Medji dol, 1000 m; Struška Kočna, 1600 m; Debelo brdo, pod Belščico, $1200 \mathrm{~m}$; Potoška planina pod Belščico, 1300 m; Javorniški Rovt, 1100 m; dolina Završnica, pod Begunjščico, 1000 m; Preval pod Begunjščico (Merčun LJU 1929); Zelenica (Fr. Plemelj LJU 1848); Stol, 1200 m; Begunjščica, 1000 m; Košuta: planina Kofce (Piskernik 1977, det. Martinčič); Vranček pod Ljubeljem, 850 m; Jelendol; Jelendol pod Košuto (Grom LJU 1959); Jelendol, proti Čizovcu, $1400 \mathrm{~m}$ (Marinček \& Čarni 2010); Jelendol, pod Penatco, 900 m; Spodnje Jezersko: Tisovec, 800 m; Zgornje Jezersko: med Roblekom in Vršnikom, 970 m (Marinček \& Čarni 2007); Zgornje Jezersko: pod Roblekom, 1000 m; pod Pavličevim sedlom, 1250 m (Grom LJU 1970); pod Pavličevim sedlom, pri kmetiji Covnik, 1200 m; Olševa: sev. pobočje, $1300 \mathrm{~m}$; Olševa, $1400 \mathrm{~m}(\mathrm{Ku}-$ tnar et al. 2006, det. Martinčič); Olševa: Zadnji travnik, 1400 m (Piskernik \& Martinčič 1970); Sleme nad dolino Koprivno, 1200 m (Grom LJU 1964); Mozganov vrh, 590 m (Piskernik 1977, det. Martinčič); dolina Koprivna (Piskernik 1977, det. Martinčič); Koprivna, 950 m; Javorje pod Malo Peco, 1320 m (Kutnar et al. 2006); Podpeca, 920 m (Grom LJU 1970); Čofatija nad Črno na Koroškem, 1270 m (Grom LJU 1964); Najbrževo pod Malo Peco, 1400 m (Kutnar et al. 2006, det. Martinčič); Čofatijev vrh nad dolino Toplo (Piskernik 1977, det. Martinčič); Peca (Piskernik 1977, det. Martinčič); dolina Topla, nad Fajmutom, 1400 m; dolina Topla, pod Florinom, $850 \mathrm{~m}$; nad Solčavo, levi breg reke Savinje, $700 \mathrm{~m}$ (Grom LJU 1970); Olševa, vzh. rob, 1320 m (Grom LJU 1970); Sv. Duh pod Olševo, 1230 m (Grom LJU 1970); Strevčev vrh pri Olševi, 1500 m; pri Črni 
na Koroškem, proti Javorju, $650 \mathrm{~m}$; Ludranski vrh, 1020 m (Grom LJU 1960); Ludranski vrh: Podgora (Grom LJU 1960); Jazbina pri Žerjavu, 880 m, (Piskernik 1977, det. Martinčič); Uršlja gora: Črni vrh, 1010 m (Grom LJU 1958); Blatnica, vzh. od Uršlje gore, 900 m (Piskernik 1977, det. Martinčič); Kozarnica, vzh. od Uršlje gore, 1000 m (Piskernik 1977, det. Martinčič); Uršlja gora, 1500 m; Plešivec (Piskernik 1977, det. Martinčič); Bačovski vrh, 1000 m; Zgornji Razbor, 700 m; Završe nad Mislinjo (Piskernik 1977, det. Martinčič); Draga pri Begunjah na Gorenjskem, 690 m; Podljubelj, 860 m (Grom LJU 1963); Javorniško sedlo (za Storžičem), 1400 m; Stegovnik (Piskernik 1977, det. Martinčič).

Dicranum spurium Hedw. - bor-mont: Sv. Danijel nad Prevaljami (Grom LJU 1958).

*Didymodon acutus (Brid.) K. Saito - merid-temp: Srednji vrh nad Gozd Martuljkom, 1000 m; nad Gozd Martuljkom, 800 m; Potoška planina pod Belščico, 1300 m; Spodnje Jezersko: Tisovec, $850 \mathrm{~m}$; dolina Topla, nad Fajmutom, 1000 m; Sv. Duh pod Olševo, pri Potočniku, 1200 m; Smokuč pri Begunjah na Gorenjskem, $540 \mathrm{~m}$; Čadovlje pri Tržiču, $600 \mathrm{~m}$; pod Javorniškim sedlom (za Storžičem), $800 \mathrm{~m}$.

*Didymodon asperifolius (Mitt.) Crum, Steere \& Anderson - arkt-alp: Lajb pod Ljubeljem, $800 \mathrm{~m}$.

*Didymodon cordatus Jur. - temp-subkont: nad Podkorenom, 950 m; Ljubelj: Sv. Ana, 900 m; Jelendol, pod Penatco, $900 \mathrm{~m}$; pod Pavličevim sedlom, pri kmetiji Covnik, 1200 m; dolina Topla, nad Fajmutom, 1100 m.

Didymodon fallax (Hedw.) R.H. Zander - ubi$k v$ : Hruški vrh, 1700 m; Sv. Križ pri Planini pod Golico, 1100 m; Črni vrh nad Jesenicami, $1400 \mathrm{~m}$; Spodnje Jezersko: Tisovec, $850 \mathrm{~m}$; dolina Topla, pri Florinu, $900 \mathrm{~m}$; dolina Topla, pod Burjakovim hribom, $700 \mathrm{~m}$; dolina Topla, nad Fajmutom, 1100 m; Olševa: Zadnji travnik, 1400 m; Sv. Duh pod Olševo, pri Potočniku, 1200 m; Strevčev vrh pri Olševi, nad Rogarjem, 1400 m; dolina Tržiške Bistrice pri Tržiču (Glowacki 1912).

Didymodon ferrugineus (Schimp. ex Besch.) M. O. Hill - bor-temp: nad Gozd Martuljkom, $800 \mathrm{~m}$; pri Valvazorjevem domu pod Stolom, 1200 m; Ljubelj: Sv. Ana, 900 m; Spodnje Jezersko: Tisovec, $850 \mathrm{~m}$; Mala Peca, $1400 \mathrm{~m}$; dolina Topla, nad Fajmutom, 1100 m; Uršlja gora, 1600 m; Uršlja gora, vzh. pobočje, 1100 m; Ple- šivški mlin pod Uršljo goro, $900 \mathrm{~m}$; Draga pri Begunjah na Gorenjskem, 690 m; dolina Tržiške Bistrice pri Tržiču (Glowacki 1912); Čadovlje pri Tržiču, 600 m; pod Javorniškim sedlom (za Storžičem), $800 \mathrm{~m}$.

VU-Didymodon giganteus (Funck) Jur. - subarkt-subalp: Hudičev most pri Tržiču (Glowacki 1912).

Didymodon insulanus (De Not.) M. O. Hill - subtemp: Uršlja gora, pobočje nad Ravnami, $800 \mathrm{~m}$ (Glowacki 1908).

*Didymodon rigidulus Hedw. - bor-temp: med Gozd Martuljkom in Belco, 700 m; nad Gozd Martuljkom, 800 m; med Javornikom (Jesenice) in Javorniškim Rovtom, 800 m; Mala Peca, $1400 \mathrm{~m}$; Uršlja gora, $1400 \mathrm{~m}$; Plešivški mlin pod Uršljo goro, $900 \mathrm{~m}$; Draga pri Begunjah na Gorenjskem, 690 m; Smokuč pri Begunjah na Gorenjskem, $540 \mathrm{~m}$.

*var. validus (Limpr.) Düll - bor-mont: Dolžanova soteska, pri vasi Dolina, $750 \mathrm{~m}$.

*Didymodon spadiceus (Mitt.) Limpr. - temp: Vajnež, 2100 m; dolina Završnica, 800 m; Vranček pod Ljubeljem, 850 m; dolina Koprivna, $1300 \mathrm{~m}$; dolina Topla, $750 \mathrm{~m}$.

Diphyscium foliosum (Hedw.) D. Mohr - bor-temp: Krvavka, $1000 \mathrm{~m}$; Črni vrh nad Jesenicami, 1400 m; Velika Golica (Dolšak LJU 1919); Javorniški Rovt, 1100 m; Begunjščica, nad Poljško planino, 1500 m; Čofatija nad dolino Meže (Grom LJU 1964).

Distichium capillaceum (Hedw.) Bruch \& Schimp. - bor-mont: Uršlja gora (Wallnöfer 1888). Dovška Baba, $1800 \mathrm{~m}$; dolina Belce (Grom LJU 1965); Velika Golica, 1400 m; Sv. Križ pri Planini pod Golico (Müllner 1893); Krvavka, 1750 m; Hruški vrh, 1700 m; Klek, 1600 m; Struška Kočna, 1600 m; Vajnež, 2100 m; Stol, 2000 m; Begunjščica, 2000 m; Ljubelj, 1000 m; Najbrževo pod Malo Peco, 1400 m (Kutnar et al. 2006, det. Martinčič); Uršlja gora, 1600 m.

Distichium inclinatum (Hedw.) Bruch \& Schimp. - subarkt-subalp: Krvavka, 1750 m; Struška Kočna, 1600 m; Vajnež, 2100 m (Martinčič 2009); Begunjščica, 2000 m; Stol, 2000 m; Olševa (Wallnöfer 1888, Breidler 1891).

Ditrichum flexicaule (Schwaegr.) Hampe - bor-temp: Uršlja gora (Wallnöfer 1888); Uršlja gora: pobočje nad Ravnami (Glowacki 1908); nad Podkorenom, 950 m; Dovška Baba, 1800 m; Velika Golica, 1400 m; Krvavka, 1000 m; planina Pusti rovt pod Korenščico, 1500 m; Medji dol (Wallnöfer 1888); Javorniška Kočna nad Jeseni- 
cami (Wallnöfer 1888); Vajnež, 2100 m; Begunjščica, 1000 m, 1400 m; Stol, 2000 m; Stol (Dolšak LJU ; 1938); Ljubelj: Sv. Ana, 900 m; dolina Koprivna (Wraber M. 1963); Olševa: Zadnji travnik, 1400 m; Olševa, sev. pobočje, 1300 m; Čofatijev vrh nad dolino Koprivno (Grom LJU 1960); nad Solčavo, levi breg reke Savinje (Grom LJU 1970); Uršlja gora: Kozakinovo; Uršlja gora, 1650 m; Podgorje pri Slovenj Gradcu, 450 m; Draga pri Begunjah na Gorenjskem, $690 \mathrm{~m}$; Dolžanova soteska, pri vasi Dolina, $600 \mathrm{~m}$.

Ditrichum heteromallum (Hedw.) E. Britton bor-temp: Uršlja gora: pobočje nad Ravnami (Glowacki 1908); Javorniško sedlo (za Storžičem), $1400 \mathrm{~m}$.

Ditrichum pallidum (Hedw.) Hampe - temp-subkont: dolina Koprivna (Wraber 1963).

Ditrichum gracile (Mitt.) Kuntze - bor-temp: Uršlja gora: pobočje nad Ravnami, 1000 m (Glowacki 1908).

NT-Drepanocladus aduncus (Hedw.) Warnst. bor-temp: dolina reke Bistre pri Črni na Koroškem (Wallnöfer 1888).

*VU-Drepanocladus polygamus (Schimp.) Hedenäs - bor-temp: Olševa: Zadnji travnik, $1400 \mathrm{~m}$.

Encalypta affinis R. Hedw. - arkt-alp: Begunjščica, zah. pobočje, 1500 m (Martinčič 2012).

Encalypta alpina Sm. - arkt-alp: Begunjščica, 2000 m (L-2009); Olševa (Breidler 1891).

Encalypta ciliata Hedw. - bor-mont: Krvavka, $1750 \mathrm{~m}$; Begunjščica, nad Poljško planino, $1500 \mathrm{~m}$.

Encalypta streptocarpa Hedw. - bor-temp: Uršlja gora (Glowacki 1908); nad Podkorenom, $950 \mathrm{~m}$; Srednji vrh nad Gozd Martuljkom, $1000 \mathrm{~m}$; med Gozd Martuljkom in Belco, 700 m: nad Dovjem, 800 m; Krvavka, 1000 m; Korenščica, $1500 \mathrm{~m}$; planina Pusti rovt pod Korenščico, $1500 \mathrm{~m}$; Medji dol (Müllner 1893); Debelo brdo pod Belščico, 1200 m; Gozdašnica, nad dolino Završnico, 800 m; Stol, 2000 m; pod Ljubeljem, $950 \mathrm{~m}$; Jelendol, pod Penatco, 900 m; Spodnje Jezersko: Tisovec, 850 m; pod Pavličevim sedlom, pri kmetiji Covnik, 1200 m; dolina Koprivna, 1300 m; Olševa: Zadnji travnik, 1400 m; dolina Topla, nad Fajmutom, 1400 m; Olševa: pod Potočko zijalko, $1600 \mathrm{~m}$; dolina reke Bistre, $650 \mathrm{~m}$; Uršlja gora, 1400 m; Podgorje pri Slovenj Gradcu, 450 m; Spodnji Razbor pri Mislinjski Dobravi, 500 m; Čadovlje pri Tržiču, 600 m; Dolžanova soteska, pri vasi Dolina, 750 m; Javorniško sedlo (za
Storžičem), 1400 m; Beli potok pri Podljubelju (Glowacki 1912).

Encalypta vulgaris Hedw. - merid-temp: Dovška Baba, 1800 m; Krvavka, 1000 m; Medji dol (Müllner 1893); Vajnež, 2100 m; Begunjščica, 1000 m; Stol, 1200 m; Sv. Peter nad Begunjami na Gorenjskem, 700 m (Piskernik 1977, det. Martinčič).

Entodon concinnus (De Not.) Paris - bor-mont: nad Podkorenom, $950 \mathrm{~m}$; Črni vrh nad Jesenicami, $1400 \mathrm{~m}$; pri Valvazorjevem domu pod Stolom, 1200 m (Martinčič 2012); Begunjščica, 1000 m; Vranček pod Ljubeljem, 850 m; dolina Topla, nad Fajmutom, 1100 m; grad Kamen pri Begunjah (Glowacki 1912); Čadovlje pri Tržiču, $600 \mathrm{~m}$.

Entodon schleicheri (Schimp.) Demet. - temp-subkont: Draga pri Begunjah na Gorenjskem, $690 \mathrm{~m}$.

Eucladium verticillatum (With.) Bruch \& Schimp. - merid-temp: nad Podkorenom, 950 m; dolina Završnica, pod Begunjščico, $1000 \mathrm{~m}$; dolina reke Bistre pri Črni na Koroškem (Wallnöfer 1888).

var. commutatum (Glow.) Podp. - submed: dolina Završnica, pod Begunjščico, $1000 \mathrm{~m}$.

Eurhynchiastrum pulchellum (Hedw.) Ignatov \& Huttunen: Uršlja gora: pobočje nad Ravnami (Glowacki 1908).

var. pulchellum - subbor: Krvavka, vrh, 1750 m; Korenščica, $1600 \mathrm{~m}$; Potoška planina, pod Belščico, $1300 \mathrm{~m}$; Debelo brdo pod Belščico, $1200 \mathrm{~m}$; Ljubelj, $1000 \mathrm{~m}$; Medvodje pod Penatco, $850 \mathrm{~m}$; dolina Koprivna, $1200 \mathrm{~m}$; Mala Peca, 1400 m; dolina Topla, nad Fajmutom, 1100 m; Strevčev vrh pri Olševi, nad Rogarjem, 1400 m; Uršlja gora, 1500 m (Martinčič 2009); Plešivški mlin pod Uršljo goro, 900 m; Čadovlje pri Tržiču, $600 \mathrm{~m}$.

*var. diversifolium (Bruch et al.) G.E.O. Jensen - subarkt-subalp: Hruški vrh, 1700 m (Martinčič 2012).

Eurhynchium angustirete (Broth.) T.J. Kop. temp-subkont: Peč, 1100 m; Medvedjek nad Podkorenom, 1000 m; nad Dovjem, 800 m; Velika Golica, 1400 m; Potoška planina pod Belščico, 1300 m; Gozdašnica, nad dolino Završnico, 800 m; Begunjščica, 1000 m; Jelendol, 1350 m (Marinček \& Čarni 2007); Medvodje pod Penatco, $850 \mathrm{~m}$; Spodnje Jezersko: Tisovec, 850 m; pod Pavličevim sedlom, pri kmetiji Covnik, 1200 m; dolina Koprivna (Piskernik 1977, det. Martinčič); Olševa, sev. pobočje, 1300 m; 
Olševa, 1400 m (Kutnar et al. 2006, det. Martinčič); Čofatija, levi breg Meže nad Črno na Koroškem (Grom LJU 1964); Peca, 1500 m (Piskernik 1977, det. Martinčič); Najbrževo pod Malo Peco, 1400 m (Kutnar et al. 2006, det. Martinčič); pri Solčavi, levi breg reke Savinje, $750 \mathrm{~m}$ (Grom LJU 1970); Sleme nad dolino Koprivno (Grom LJU 1964); Strevčev vrh pri Olševi, nad Rogarjem, 1400 m; Ludranski vrh: Podgora (Grom LJU 1960); nad Črno na Koroškem, 1200 m (Grom LJU 1970, det. Martinčič); Uršlja gora: Ravnjakov vrh, 910 m (Grom LJU 1958); Uršlja gora ( Martinčič 1976); Uršlja gora, 1000 m (Piskernik 1977, det. Martinčič); Uršlja gora: Kozarnica, 1000 m (Piskernik 1977, det. Martinčič); Uršlja gora, 1080 m (leg. Piskernik); pod Uršljo goro, 1190 m (Marinček \& Čarni 2007); Zgornji Razbor, 700 m; Podljubelj, 860 m (Grom LJU 1963); Javorniško sedlo (za Storžičem), $1400 \mathrm{~m}$.

*Eurhynchium striatum (Hedw.) Schimp. temp-subatl: Zgornje Jezersko: pod Roblekom, $1000 \mathrm{~m}$; Čadovlje pri Tržiču, $600 \mathrm{~m}$.

Fissidens adianthoides Hedw. - bor-temp: Uršlja gora (Wallnöfer 1888); dolina reke Bistre pri Črni na Koroškem (Wallnöfer 1888).

Fissidens bryoides Hedw. - temp: Javorniški Rovt, 1100 m; Sv. Duh pod Olševo, pri Potočniku, $1200 \mathrm{~m}$.

Fissidens dubius P. Beauv. - temp: Peč, 1100 m; Uršlja gora: pobočje nad Ravnami (Glowacki 1908); Belca pri Dovjem; nad Gozd Martuljkom, 800 m; Srednji vrh nad Gozd Martuljkom, 1000 m; med Gozd Martuljkom in Belco, 700 m; nad Dovjem, $800 \mathrm{~m}$; Črni vrh nad Jesenicami, 1400 m; Krvavka, 1000 m; Velika Golica, 1400 m; Korenščica; Javorniški Rovt, 1100 m; Vajnež, 2100 m; Debelo brdo pod Belščico, 1200 m; Gozdašnica, nad dolino Završnico, $800 \mathrm{~m}$; dolina Završnica, pod Begunjščico, $800 \mathrm{~m}$; Stol, 2000 m; Begunjščica, 1000 m; Ljubelj, 1000 m; Vranček pod Ljubeljem, 850 m; Jelendol, pod Penatco, $900 \mathrm{~m}$; pod Pavličevim sedlom, pri kmetiji Covnik, 1200 m; Olševa, sev. pobočje, 1300 m; Olševa, 1400 m (Kutnar et al. 2006, det. Martinčič); dolina Topla pod Peco (Piskernik 1977, det. Martinčič); Peca (Piskernik 1977, det. Martinčič); med Solčavo in Logarsko dolino, levi breg Savinje, 700 m (Grom LJU 1970); Olševa (Breidler 1891); Strevčev vrh pri Olševi, 1500 m; dolina reke Bistre pri Črni na Koroškem (Wallnöfer 1888); Črna na Koroškem, breg reke Bistre, $620 \mathrm{~m}$ (Juvan 2008); dolina reke Bistre,
650 m; Uršlja gora, 1300 m (Piskernik 1977, det. Martinčič); Uršlja gora, $1500 \mathrm{~m}$; Uršlja gora (Wallnöfer 1888); Ravnjakov vrh nad Prevaljami, 860 m (Grom LJU 1958); Podljubelj, 860 m (Grom LJU 1961); Čadovlje pri Tržiču, 600 m; Javorniško sedlo (za Storžičem), 1400 m; Dolžanova soteska, pri vasi Dolina, $750 \mathrm{~m}$; Beli potok pri Podljubelju (Glowacki 1912).

var. mucronatus Breidl.: Uršlja gora, pobočje nad Ravnami (Glowacki 1908); nad Gozd Martuljkom, 800 m; Velika Golica, 1400 m; planina Pusti rovt pod Korenščico, 1500 m; Medji dol, 1000 m; Begunjščica, 1000 m; pod Ljubeljem, 950 m; Jelendol, pod Penatco, 900 m; Olševa, sev. pobočje, 1300 m; Olševa, 1400 m (Kutnar et al. 2006, det. Martinčič); Javorje pod Malo Peco, 1320 m (Kutnar et al. 2006, det. Martinčič); Strevčev vrh pri Olševi, $1500 \mathrm{~m}$.

*Fissidens osmundoides Hedw. - subarkt-subalp: pod Pavličevim sedlom, pri kmetiji Covnik, $1200 \mathrm{~m}$;

Fissidens taxifolius Hedw. - merid-temp: Peč, pri planinskem domu Tromeja, $1200 \mathrm{~m}$; Črni vrh nad Jesenicami, 1400 m (Martinčič 2004); planina Pusti rovt, pod Korenščico, 1500 m; Struška Kočna, 1600 m; Javorniški Rovt, 1100 m; Zelenica (Müllner 1893); pri Valvazorjevem domu pod Stolom, 1200 m; Vranček pod Ljubeljem, $850 \mathrm{~m}$; Jelendol, pod Penatco, $900 \mathrm{~m}$; Jelendol, 1350 m (Marinček \& Čarni 2007); Spodnje Jezersko: Tisovec, $850 \mathrm{~m}$; Jezersko: med Roblekom in Vršnikom, 970 m (Marinček \& Čarni 2007); Olševa: Zadnji travnik, 1400 m; dolina Topla, nad Fajmutom, 1100 m; Strevčev vrh pri Olševi, $1500 \mathrm{~m}$; pod Uršljo goro, $1190 \mathrm{~m}$ (Marinček \& Čarni 2007); Uršlja gora, 1500 m; Uršlja gora: Kozarnica, $1000 \mathrm{~m}$ (Piskernik 1977, det. Martinčič); Draga pri Begunjah na Gorenjskem, 690 m (Martinčič 1976); Sv. Peter nad Begunjami na Gorenjskem, 700 m (Piskernik 1977, det. Martinčič); Dolžanova soteska, pri vasi Dolina, $750 \mathrm{~m}$.

*Fontinalis antipyretica Hedw. subsp. antipyretica - bor-temp: Olševa, juž. pobočje, $800 \mathrm{~m}$.

Funaria hygrometrica Hedw. - ubikv: Rateče, 900 m; Krvavka, 1750 m; Sv. Križ pri Planini pod Golico, 1000 m; Javorniški Rovt, 1100 m; Peca (leg. Planina); pri Javorniku blizu Jesenic (Plemelj V. LJU 1873); Smokuč pri Begunjah na Gorenjskem, $540 \mathrm{~m}$

Grimmia elatior Bruch ex Bals.-Criv. \& De Not. - bor-mont: nad Dovjem, 800 m; vas Dolina pri Tržiču, 700 m (Glowacki 1912). 
Grimmia hartmannii Schimp. - subbor: dolina Koprivna, $950 \mathrm{~m}$; dolina reke Bistre pri Črni na Koroškem (Wallnöfer 1888); dolina Tržiške Bistrice (Glowacki 1912).

Grimmia muehlenbeckii Schimp. - subtemp: nad Hudičevim mostom pri Tržiču (Glowacki 1912).

Grimmia ovalis (Hedw.) Lindb. - subbor: dolina reke Bistre pri Črni na Koroškem (Wallnöfer 1888).

*Grimmia pulvinata (Hedw.) Sm. var. pulvinata - merid-temp: nad Gozd Martuljkom, 800 m; nad Dovjem, 800 m; Stolec nad Tržičem, $560 \mathrm{~m}$.

*Gymnostomum aeruginosum Sm. - subbor: pod Pavličevim sedlom, pri kmetiji Covnik, 1200 m; Olševa: Potočka zijalka, vhod, 1700 m; Sv. Križ pri Planini pod Golico, $1000 \mathrm{~m}$.

Gymnostomum calcareum Nees \& Hornsch. merid-temp: Ljubelj, 1000 m; Hudičev most pri Tržiču (Glowacki 1912); Podgorje pri Slovenj Gradcu, 450 m.

NT-Hamatocaulis vernicosus (Mitt.) Hedenäs bor-mont: barje pod Pavličevim sedlom, blizu kmetije Covnik, 1150 m; Olševa: Zadnji travnik, $1400 \mathrm{~m}$; Jelendol.

Hedwigia ciliata (Hedw.) P. Beauv. - bor-temp: dolina Tržiške Bistrice (Glowacki 1912); Golica, 1800 m; Ljubelj: Sv. Ana, 900 m; Koprivna: Čofatijev vrh (Grom LJU 1960); Sleme nad dolino Koprivno (Grom LJU 1964).

var. leucophaea Bruch \& Schimp.: Sv. Križ pri Planini pod Golico (Dolšak LJU 1938); dolina Koprivna, $950 \mathrm{~m}$.

Herzogiella seligeri (Brid.) Z. Iwats. - subtemp: Peč, pri planinskem domu Tromeja, $1200 \mathrm{~m}$; Korensko sedlo, 1060 m; med Gozd Martuljkom in Belco, $700 \mathrm{~m}$; Sv. Križ pri Planini pod Golico, 1000 m; Črni vrh nad Jesenicami, 1400 m; Krvavka, 1000 m; Medji dol (Wallnöfer 1888); Medji dol, 1000 m; Javorniški Rovt, 1100 m; Potoška planina pod Belščico, 1300 m; med Javornikom (Jesenice) in Javorniškim Rovtom, 700 m; Zelenica (Müllner 1893); Begunjščica, $1000 \mathrm{~m}$; Ljubelj, $950 \mathrm{~m}$; Zgornje Jezersko: pod Roblekom, 1000 m; pod Pavličevim sedlom, pri kmetiji Covnik, 1200 m; dolina Koprivna (Piskernik 1977, det. Martinčič); dolina Koprivna, 950 m; dolina Topla pod Peco, 1200 m (Piskernik 1977, det. Martinčič); Najbrževo pod Malo Peco, 1400 m (Kutnar et al. 2006, det. Martinčič); dolina Topla, nad Florinom, 850 m; pod Olševo, 1290 m (Grom LJU 1970, det. Martinčič); Olševa, pod Potočko zijalko, 1600 m; Olševa, juž. pobočje, 800 m; Javorje pri Žerjavu (Piskernik 1977, det. Martinčič); Uršlja gora (Wallnöfer 1888); Uršlja gora, 1400 m; Zgornje Jezersko: pod Roblekom, 1000 m; Ludranski vrh (Grom LJU 1960); Bačovski vrh, 1000 m; Zgornji Razbor, 700 m; Draga pri Begunjah na Gorenjskem, $690 \mathrm{~m}$; Dolžanova soteska, pri vasi Dolina, $750 \mathrm{~m}$; Javorniško sedlo (za Storžičem), $1400 \mathrm{~m}$.

Herzogiella striatella (Brid.) Z. Iwats. - bor-mont: Draga pri Begunjah na Gorenjskem (Martinčič 1976).

Heterocladium dimorphum (Brid.) Schimp. - bor-mont: Medvedjek nad Podkorenom, $1000 \mathrm{~m}$; Krvavka, 1600 m; Javorniški Rovt, 1100 m (L2005); Koprivna: Mozganov vrh, 590 m (Piskernik 1977, det. Martinčič); Olševa, sev. pobočje (Breidler 1891); Olševa, sev. pobočje, 1300 m; Olševa, 1400 m (Kutnar et al. 2006, det. Martinčič); Strevčev vrh pri Olševi, $1500 \mathrm{~m}$; Javorniško sedlo (za Storžičem), $1400 \mathrm{~m}$.

Homalia trichomanoides (Hedw.) Brid. - subtemp: Spodnji Razbor pri Mislinjski Dobravi, 500 m (Martinčič 2009).

Homalothecium lutescens (Hedw.) H. Rob. - merid-temp: Srednji vrh nad Gozd Martuljkom, 1000 m; Medji dol, 1000 m; Potoška planina pod Belščico, $1300 \mathrm{~m}$; Olševa, juž. pobočje, 800 m; Uršlja gora (Grom LJU 1959); Draga pri Begunjah na Gorenjskem, $690 \mathrm{~m}$.

Homalothecium philippeanum (Spruce) Schimp. - temp-subkont: Peč, 1100 m; Uršlja gora ( Glowacki 1908); Srednji vrh nad Gozd Martuljkom, 1000 m; nad Gozd Martuljkom, 800 m; Krvavka, 1750 m; Belščica (Paulin 1914); Vajnež, $2100 \mathrm{~m}$; pri Valvazorjevem domu pod Stolom, 1200 m; Gozdašnica, nad dolino Završnico, $800 \mathrm{~m}$; med Javornikom (Jesenice) in Javorniškim Rovtom, 800 m; Stol (Paulin 1914); Stol, 1600 m (Dolšak LJU 1938); Begunjščica, 1000 m, 2000 m; Begunjščica nad Poljško planino, $1500 \mathrm{~m}$; Vranček pod Ljubeljem, $850 \mathrm{~m}$; Mala Peca, 1400 m; Javorje pod Malo Peco, 1320 m (Kutnar et al. 2006, det. Martinčič); Peca, 1500 m (Piskernik 1977, det. Martinčič); dolina Topla, 800 m; Olševa: pod Potočko zijalko, 1600 m; Olševa (Breidler 1891); Olševa, juž. pobočje, $800 \mathrm{~m}$; Sv. Duh pod Olševo, pri Potočniku, $1200 \mathrm{~m}$; Uršlja gora, $1000 \mathrm{~m}$ (Piskernik 1977, det. Martinčič); Uršlja gora: Kozarnica, 1000 m (Piskernik 1977, det. Martinčič); Uršlja gora, 1500 m; Sv. Peter nad Begunjami na Gorenjskem, 700 m (Piskernik 1977, det. Mar- 
tinčič); Draga pri Begunjah na Gorenjskem, 690 m; Stolec nad Tržičem, 560 m; Dolžanova soteska, $600 \mathrm{~m}$.

Homalothecium sericeum (Hedw.) Schimp. - merid-temp: nad Gozd Martuljkom, 800 m; Velika Golica (Müllner 1893); Gozdašnica, nad dolino Završnico, $800 \mathrm{~m}$; Jelendol, pod Penatco, 900 m; Spodnje Jezersko: Tisovec, 850 m; Javorje pod Malo Peco, $1320 \mathrm{~m}$ (Kutnar et al. 2006, det. Martinčič); Olševa, 1060 m (Grom LJU 1960); dolina Bistre pri Črni na Koroškem (Wallnöfer 1888); Črna na Koroškem, breg reke Bistre, 620 m (Juvan 2008); Uršlja gora: Kozarnica, 1000 m (Piskernik 1977, det. Martinčič); Uršlja gora: Kozarnica, $1150 \mathrm{~m}$ (Grom LJU 1958); Uršlja gora, juž. pobočje, 890 m (Grom LJU 1958); Uršlja gora; Završe nad Mislinjo (Piskernik 1977, det. Martinčič); Podljubelj (Grom LJU 1961); Čadovlje pri Tržiču, $600 \mathrm{~m}$; Stegovnik (Piskernik 1977, det. Martinčič).

Homomallium incurvatum (Schrad. ex Brid.) Loeske - bor-temp: nad Gozd Martuljkom, 800 m; Srednji vrh nad Gozd Martuljkom, 950 m; nad Dovjem, $800 \mathrm{~m}$; pri Valvazorjevem domu pod Stolom, 1200 m; Begunjščica, 1000 m; Vranček pod Ljubeljem, 850 m; dolina Topla, nad Fajmutom, 1100 m; Uršlja gora, 1400 m; Smokuč pri Begunjah na Gorenjskem, 540 m; Čadovlje pri Tržiču, $600 \mathrm{~m}$.

Hookeria lucens (Hedw.) Sm. - temp-subatl: med Hruško planino pod Rožco in Sv. Križem pri Planini pod Golico, 1100 m (L-2004); pod Pavličevim sedlom, pri kmetiji Covnik, 1200 m; Strevčev vrh pri Olševi, nad Rogarjem, 1400 m (Martinčič 2004); Sv. Duh pri Solčavi (Grom LJU 1960); Podljubelj (Grom LJU 1963).

Hygroamblystegium tenax (Hedw.) Jenn. - temp: v potoku Mošenik pri Podljubelju, 700 m (Martinčič 2005).

*Hygroamblystegium varium (Hedw.) Mönkm. temp: nad Dovjem, 800 m; Lajb pod Ljubeljem, $750 \mathrm{~m}$; Jelendol, pod Penatco, $900 \mathrm{~m}$.

Hygrohypnum luridum (Hedw.) Jenn. - bor-temp: Srednji vrh nad Gozd Martuljkom, 1000 m; Hruška planina pod Rožco, 1200 m; Sv. Križ pri Planini pod Golico, 1000 m; Črni vrh nad Jesenicami, $1400 \mathrm{~m}$; planina Pusti Rovt pod Korenščico, 1500 m; Medji dol, 1000 m; med Javornikom (Jesenice) in Javorniškim Rovtom, 800 m; Potoška planina pod Belščico, 1300 m; nad planino Vrtačo; dolina Završnica, 800 m; Jelendol, pod Penatco, 900 m. Sv. Duh pod Olševo, pri Potočniku, 1200 m; pod Pavličevim sedlom, pri kmetiji Covnik, 1200 m; dolina Koprivna, ob reki Koprivni, $900 \mathrm{~m}$; dolina Topla, pri Florinu, $900 \mathrm{~m}$; Spodnje Jezersko: Tisovec, $850 \mathrm{~m}$; Strevčev vrh pri Olševi, $1500 \mathrm{~m}$; pri Plešivškem mlinu pod Uršljo goro, 900 m; Uršlja gora, 1500 m; v Tržiški Bistrici pri Tržiču; Čadovlje pri Tržiču, $600 \mathrm{~m}$; Jelendol pod Košuto (Wallnöfer 1888); Dolžanova soteska, pri vasi Dolina, $750 \mathrm{~m}$.

*var. subsphaericarpon (Schleich ex Brid.) C. Jens. - bor-mont: Jelendol, pod Penatco, $900 \mathrm{~m}$. Hylocomiastrum umbratum (Hedw.) M. Fleisch. - bor-mont: dolina Koprivna, $950 \mathrm{~m}$.

Hylocomium splendens (Hedw.) Schimp. - subbor: med Gozd Martuljkom in Belco, $700 \mathrm{~m}$ Dovška Baba, 1800 m; Črni vrh nad Jesenicami, 1400 m; Hruški vrh, 1700 m; Velika Golica, 1400 m; Struška Kočna, 1600 m; Javorniški Rovt, 1100 m; Begunjščica, 1000 m; Vranček pod Ljubeljem, 850 m; Spodnje Jezersko: Tisovec, $850 \mathrm{~m}$; Zgornje Jezersko: pod Roblekom, 1000 m; pod Pavličevim sedlom, 1250 m (Grom LJU 1970); Olševa: sev. pobočje, $1300 \mathrm{~m}$; Olševa, 1400 m (Kutnar et al. 2006, det. Martinčič); Olševa: Zadnji travnik, 1400 m (Piskernik \& Martinčič 1970); dolina Koprivna, 500 m (Piskernik 1977, det. Martinčič); dolina Koprivna, 1200 m; Peca, 1300 m (Piskernik, 1977, det. Martinčič); pod Peco (Piskernik 1977, det. Martinčič); dolina Topla, nad Fajmutom, $1400 \mathrm{~m}$; pod Olševo, $1120 \mathrm{~m}$ (Grom LJU, det. Martinčič); Strevčev vrh pri Olševi, nad Rogarjem; Olševa: pri Potočki zijalki, $1680 \mathrm{~m}$ (Grom LJU 1970, det. Martinčič); Olševa, 1350 m (Piskernik 1977, det. Martinčič); nad Solčavo, levi breg Savinje, 700 m (Grom LJU 1970, det. Martinčič); Uršlja gora, 1300 m (Piskernik 1977, det. Martinčič); Uršlja gora: Kozakinovo; Uršlja gora, 1650 m; Draga pri Begunjah na Gorenjskem, 690 m; Podljubelj, 860 m (Grom LJU 1963, det. Martinčič); Stegovnik (Piskernik 1977, det. Martinčič).

Hymenostylium recurvirostrum (Hedw.) Dix. bor-mont: Srednji vrh nad Gozd Martuljkom, 1000 m; Uršlja gora (Wallnöfer 1888); Olševa: Potočka zijalka, vhod, $1700 \mathrm{~m}$; pod Javorniškim sedlom (za Storžičem), $800 \mathrm{~m}$.

*Hypnum andoi A.J.E. Smith - temp-subatl: Hruška planina pod Rožco, 1200 m; Begunjščica, 1900 m; dolina Koprivna, 950 m; Stolec nad Tržičem, $560 \mathrm{~m}$.

*Hypnum callichroum Brid. - subarkt-subalp: pod Pavličevim sedlom, pri kmetiji Covnik, 1200 m. 
Hypnum cupressiforme Hedw. - ubikv: Medvedjek nad Podkorenom, 1000 m; nad Dovjem, 800 m; Gozdašnica, nad dolino Završnico, $800 \mathrm{~m}$; Spodnje Jezersko: Tisovec, 850 m; pod Pavličevim sedlom, pri kmetiji Covnik, $1200 \mathrm{~m}$; dolina Koprivna (Piskernik 1977, det. Martinčič); dolina Koprivna, 950 m; Najbrževo pod Malo Peco 1400 m (Kutnar et al. 2006, det. Martinčič); Javorje pod Malo Peco, 1320 m (Kutnar et al. 2006, det. Martinčič); dolina Topla pod Peco (Piskernik 1977, det. Martinčič); dolina Topla, nad Fajmutom, 1100 m; Uršlja gora: Kozakinovo; Uršlja gora: Plešivec, 890 m (Grom LJU 1958); Završe nad Mislinjo (Piskernik 1977, det. Martinčič); Sv. Peter nad Begunjami na Gorenjskem (Piskernik 1977, det. Martinčič); Draga pri Begunjah na Gorenjskem, $690 \mathrm{~m}$; Dobrča (Piskernik 1977, det. Martinčič); Stegovnik (Piskernik 1977, det. Martinčič).

var. cupressiforme: Peč, pri planinskem domu Tromeja, 1200 m; Rateče, 900 m; Sv. Križ pri Planini pod Golico, 1000 m; Črni vrh nad Jesenicami, 1400 m; Hruška planina pod Rožco, $1200 \mathrm{~m}$; med Javornikom (Jesenice) in Javorniškim Rovtom, 800 m; Javorniški Rovt, 1100 m; Debelo brdo pod Belščico, 1200 m; Jelendol, pod Penatco, $900 \mathrm{~m}$; Medvodje pod Penatco, $850 \mathrm{~m}$; dolina Završnica, $800 \mathrm{~m}$; Begunjščica, 1000 m; Ljubelj, 1000 m; Ljubelj: Sv. Ana, $900 \mathrm{~m}$; Vranček pod Ljubeljem, $850 \mathrm{~m}$; Lajb pod Ljubeljem, $750 \mathrm{~m}$; Spodnje Jezersko: Tisovec, 850 m; Zgornje Jezersko: pod Roblekom, $1000 \mathrm{~m}$; pod Pavličevim sedlom, pri kmetiji Covnik, 1200 m; dolina Koprivna, ob reki Koprivni, $900 \mathrm{~m}$; dolina Topla, nad Fajmutom, 1100 m; Strevčev vrh pri Olševi, nad Rogarjem, $1400 \mathrm{~m}$; dolina reke Bistre, $650 \mathrm{~m}$; Uršlja gora: pri kmetiji Plešivec, 950 m; Bačovski vrh, 1000 m; Zgornji Razbor, 700 m; Spodnji Razbor pri Mislinjski Dobravi, $500 \mathrm{~m}$; Draga pri Begunjah na Gorenjskem, 690 m; Smokuč pri Begunjah na Gorenjskem, 540 m; Čadovlje pri Tržiču, $600 \mathrm{~m}$.

*var. filiforme Brid. - temp: Javorniški Rovt, 1100 m; Begunjščica, 1000 m; dolina Završnica, 800 m; pod Ljubeljem, 950 m; Zgornje Jezersko: pod Roblekom, 1000 m; pod Pavličevim sedlom, pri kmetiji Covnik, $1200 \mathrm{~m}$; dolina Koprivna, 900 m; dolina Topla, nad Fajmutom, $1100 \mathrm{~m}$; Plešivški mlin pod Uršljo goro, $900 \mathrm{~m}$; Dolžanova soteska, pri vasi Dolina, $750 \mathrm{~m}$.

*var. lacunosum Brid. - temp: Medvedjek nad Podkorenom, 1000 m; Podkoren, 850 m; Medji dol, $1000 \mathrm{~m}$; dolina Topla, nad Fajmutom, $1100 \mathrm{~m}$.

*var. resupinatum (Taylor) Brid. - temp: dolina Završnica, 800 m; Spodnji Razbor pri Mislinjski Dobravi, $500 \mathrm{~m}$.

*Hypnum fertile Sendtn. - temp-subkont: Javorniško sedlo (za Storžičem), $1400 \mathrm{~m}$.

*Hypnum imponens Hedw. - temp: Medvedjek nad Podkorenom, 1000 m; Dovška Baba, 1800 m; Debelo brdo, pod Belščico, $1200 \mathrm{~m}$; Javorniški Rovt, 1100 m; Stol, 2000 m; Vranček pod Ljubeljem, 850 m; pod Pavličevim sedlom, pri kmetiji Covnik, 1200 m; Koprivna: Čofatijev vrh, $1220 \mathrm{~m}$ (Grom LJU 1960, det. Martinčič); Olševa, juž. pobočje, $800 \mathrm{~m}$; Draga pri Begunjah na Gorenjskem, $690 \mathrm{~m}$.

Hypnum jutlandicum Holmen \& E. Warncke temp: nad Gozd Martuljkom, 800 m; nad Dovjem, 800 m; Debelo brdo pod Belščico, 1200 m; dolina Završnica, 800 m; Strevčev vrh pri Olševi, nad Rogarjem, $1400 \mathrm{~m}$; Zgornje Jezersko: pod Roblekom, 1000 m (Martinčič 2012); dolina Koprivna, 950 m; dolina Topla, 850 m; Spodnje Jezersko: Tisovec, 850 m; Uršlja gora, 1600 m; Bačovski vrh, 1000 m; Spodnji Razbor pri Mislinjski Dobravi, $500 \mathrm{~m}$; C̆adovlje pri Tržiču, $600 \mathrm{~m}$.

Hypnum recurvatum (Lindb. \& Arnell) Kindb. - subarkt-subalp: Medji dol, 1000 m; Vajnež, 2100 m; Zelenica (Müllner 1893); Begunjščica, 2000 m; Sv. Duh pod Olševo, pri Potočniku, $1200 \mathrm{~m}$. Uršlja gora, $1500 \mathrm{~m}$.

*Hypnum revolutum (Mitt.) Lindb. var. revolutum - subarkt-subalp: Begunjščica, 2000 m;

*var. dolomiticum (Milde) Mönkm. - alp: Vajnež, $2100 \mathrm{~m}$; Uršlja gora, $1650 \mathrm{~m}$.

Hypnum vaucheri Lesq. - bor-mont: Dovška Baba, 1800 m; Struška Kočna, 1600 m; Stol, 2000 m; Plešivški mlin pod Uršljo goro, 900 m; grad Kamen pri Begunjah (Glowacki 1912).

Isopterygiopsis muelleriana (Schimp.) Z. Iwats. bor-mont: Sv. Duh nad Solčavo (Breidler 1891); Olševa, pod Potočko zijalko, 1600 m; Strevčev vrh pri Olševi, nad Rogarjem, 1400 m; dolina reke Bistre, $650 \mathrm{~m}$; Čadovlje pri Tržiču, $600 \mathrm{~m}$.

Isopterygiopsis pulchella (Hedw.) Z. Iwats. - bor-mont: Dovška Baba, 1800 m; Begunjščica, nad Poljško planino, $1300 \mathrm{~m}$; Stol, $1700 \mathrm{~m}$; Ljubelj, $1000 \mathrm{~m}$; dolina Koprivna: Sv. Jakob, $110 \mathrm{~m}$ (Glowacki 1908).

var. nitidula (Wahlenb.) Broth. - bor-mont: dolina Koprivna: Sv. Jakob, 1100 m (Glowacki 1908). 
Isothecium alopecuroides (Lam. ex Dubois) Isov. - bor-temp: Peč, pri planinskem domu Tromeja, 1200 m; Medvedjek nad Podkorenom, 1000 m; Belca, 1350 m; Klek, 1600 m; Krvavka, 1000 m; Črni vrh nad Jesenicami, 1400 m; Korenščica; Belščica (Plemelj V. LJU 1873); Javorniški Rovt, 1100 m; Begunjščica, 1000 m; Begunjščica, 920 m (Piskernik 1971); Košuta: Kofce, 1200 m (Piskernik 1977, det. Martinčič); Ljubelj, 1000 m; Jelendol pod Košuto (Grom LJU 1959); Jelendol, proti Čizovcu, $1400 \mathrm{~m}$ (Marinček \& Čarni 2010); Jelendol, pod Penatco, 900 m; Jezersko: med Roblekom in Vršnikom, 970 m (Marinček \& Čarni 2007); Jezersko: Kokra nad Roblekom, 1100 m (Marinček \& Čarni 2010); pod Pavličevim sedlom, 1250 m (Grom LJU 1970); pod Pavličevim sedlom, pri kmetiji Covnik, 1200 m; dolina Koprivna, 1200 m; Javorje pod Malo Peco, 1320 m (Kutnar et al. 2006, det. Martinčič); pri Solčavi, levi breg Savinje, 750 m (Grom LJU 1970); Sv. Duh pod Olševo, 1230 m (Grom LJU 1960); Strevčev vrh pri Olševi, $1500 \mathrm{~m}$; Čofatija nad Črno na Koroškem, 1200 m (Grom LJU 1964); Ludranski vrh nad Črno na Koroškem, 1020 m (Grom LJU 1960); Uršlja gora: Črni vrh, 1010 m (Grom LJU 1958); Uršlja gora, $1100 \mathrm{~m}$ (Piskernik 1977, det. Martinčič); Uršlja gora: Kozarnica, 1000 m (Piskernik 1977, det. Martinčič); pod Uršljo goro, 1190 m (Marinček \& Čarni 2007); Sv. Peter nad Begunjami na Gorenjskem, 700 m (Piskernik 1977, det. Martinčič); Draga pri Begunjah na Gorenjskem, 780 m (Piskernik 1977, det. Martinčič); Podljubelj, 1000 m (Grom LJU 1961); Javorniško sedlo (za Storžičem), 1400 m; Dolžanova soteska, pri vasi Dolina, $750 \mathrm{~m}$.

*var. robustum (Schimp.) Düll: Begunjščica, $1000 \mathrm{~m}$.

Kiaeria starkei (F. Weber\& D. Mohr) I. Hagen arkt-alp: Medji dol (Müllner 1893).

Leptobryum pyriforme (Hedw.) Wilson - bor-temp: Belščica (Paulin 1914).

*Lescuraea mutabilis (Brid.) Lindb. ex I. Hagen - temp-subkont: Klek, 1600 m; Begunjščica, nad Poljško planino, $1500 \mathrm{~m}$.

Leskea polycarpa Hedw. - temp: Velika Golica, 1400 m (Martinčič 2004); dolina Meže (Wallnöfer 1888).

Leucobryum glaucum (Hedw.) Ångstr. - temp: Klek, $1600 \mathrm{~m}$; Debelo brdo pod Belščico, 1200 m; Javorniški Rovt, 1100 m; Gozdašnica nad dolino Završnico, $800 \mathrm{~m}$; pri Valvazorjevem domu pod Stolom, $1200 \mathrm{~m}$; pod Ljube- ljem, $950 \mathrm{~m}$; Spodnje Jezersko: Tisovec, $850 \mathrm{~m}$; Zgornje Jezersko: pod Roblekom, 1000 m; dolina Topla, nad Fajmutom, 1400 m; pod Olševo, 1290 m (Grom LJU 1970); Olševa, 1500 m (leg. M. Zupančič); Olševa; pod Pavličevim sedlom, pri kmetiji Covnik, 1200 m; Strevčev vrh pri Olševi, nad Rogarjem, 1400 m; pri Črni na Koroškem, proti Javorju, 650 m; Javorje pri Žerjavu (Piskernik 1977, det. Martinčič); Bačovski vrh, 1000 m; Zgornji Razbor, 700 m; Vrhe pri Slovenj Gradcu; Kozji hrbet, 550 m (Dakskobler, Rozman \& Vreš 2012); Graška gora nad Velenjem, 740 m (Grom LJU 1965); Draga pri Begunjah na Gorenjskem, 700 m; Dolžanova soteska, pri vasi Dolina, $750 \mathrm{~m}$.

Leucodon sciuroides (Hedw.) Schwaegr. - subtemp: Rateče, 900 m; na Trebižah nad Ratečami, 1100 m; Srednji vrh nad Gozd Martuljkom, 950 m; nad Dovjem, 800 m; Medji dol, 1000 m (Martinčič 2004); Begunjščica, zah. pobočje; pod Ljubeljem, $950 \mathrm{~m}$; Jelendol, pod Penatco, $900 \mathrm{~m}$; Spodnje Jezersko: Tisovec, $850 \mathrm{~m}$; Zgornje Jezersko: pod Roblekom, 1000 m; pod Pavličevim sedlom, pri kmetiji Covnik, 1200 m; Koprivna, pri kmetiji Kumar, 1300 m; dolina reke Bistre: Knezove peči, 1100 m (Grom LJU 1960); Plešivški mlin pod Uršljo goro, $900 \mathrm{~m}$; Uršlja gora: pri kmetiji Plešivec, $950 \mathrm{~m}$; Podgorje pri Slovenj Gradcu, $450 \mathrm{~m}$; Draga pri Begunjah na Gorenjskem, 690 m; Čadovlje pri Tržiču, $600 \mathrm{~m}$. Stolec nad Tržičem, $560 \mathrm{~m}$.

var. morensis (Schwaegr.) De Not. - subatl-submed: Zgornje Jezersko: pod Roblekom, 1000 m; dolina Topla, nad Fajmutom, 1100 m; Strevčev vrh pri Olševi, 1400 m; dolina reke Bistre: Knezove peči, 1100 m (Grom LJU 1960).

Meesia uliginosa Hedw. - bor-mont: Velika Golica, 1400 m; Klek, 1600 m; Struška Kočna, 1600 m; Vajnež, 2100 m (Martinčič 2004); Zelenica (Müllner 1893); Stol, 2000 m; Olševa (Breidler 1891).

var. alpina (Funck ex Bruch) Hampe - subarkt-subalp: Olševa (Breidler 1891).

Mnium hornum Hedw. - temp: Medji dol (Müllner 1893).

Mnium lycopodioides Schwaegr. - bor-mont: Peč, pri planinskem domu Tromeja, $1200 \mathrm{~m}$; Medvedjek nad Podkorenom, 1000 m; Velika Golica, 1800 m; Krvavka, 1750 m; Potoška planina pod Belščico (Martinčič 2004); Vranček pod Ljubeljem, $850 \mathrm{~m}$; dolina Koprivna, ob reki Koprivni, 800 m; Uršlja gora, 1500 m; Javorniško sedlo (za Storžičem), $1400 \mathrm{~m}$. 
Mnium marginatum (Dicks.) P. Beauv. - bor-temp: Peč, pri planinskem domu Tromeja, $1200 \mathrm{~m}$; Srednji vrh nad Gozd Martuljkom, 1000 m; Hruška planina pod Rožco, 1200 m; Velika Golica, 1400 m; Medji dol (Müllner 1893); Medji dol, 1000 m; Vajnež, 2100 m; Javorniški Rovt, 1100 m; Begunjščica, 1000 m (Martinčič 2004); Stol, 2000 m; dolina Završnica, 800 m; Vranček pod Ljubeljem, $850 \mathrm{~m}$; Spodnje Jezersko: Tisovec, $850 \mathrm{~m}$; Olševa, sev. pobočje, $1300 \mathrm{~m}$ (Martinčič 2004); dolina Koprivna, ob reki Koprivni, 900 m; Najbrževo pod Malo Peco, 1400 m (Kutnar etal. 2006, det. Martinčič); dolina Topla, $750 \mathrm{~m}$; dolina Topla, nad Fajmutom, $1100 \mathrm{~m}$; dolina Topla, pod Burjakovim hribom, $800 \mathrm{~m}$; Strevčev vrh pri Olševi, 1500 m; Olševa, Potočka zijalka, vhod, 1700 m; dolina reke Bistre, $650 \mathrm{~m}$; Uršlja gora, $1600 \mathrm{~m}$; Uršlja gora: pri kmetiji Plešivec, $900 \mathrm{~m}$; Javorniško sedlo (za Storžičem), 1400 m; Dolžanova soteska, pri vasi Dolina, $600 \mathrm{~m}$.

*Mnium spinosum (Voit) Schwägr. - bor-mont: dolina Topla, nad Fajmutom, $1100 \mathrm{~m}$.

Mnium spinulosum Bruch \& Schimp. - temp-subkont: Dovška Baba, 1800 m (Martinčič 2004); Krvavka, 1000 m; Velika Golica, 1400 m; Struška Kočna, 1600 m; Vajnež, 2100 m; Stol, 2000 m (Martinčič 2004); Begunjščica, 1000 m.

Mnium stellare Hedw. - bor-temp: Črni Vrh nad Jesenicami, 1400 m (Martinčič 2004); Velika Golica, $1400 \mathrm{~m}$; pri Valvazorjevem domu pod Stolom, 1200 m; Debelo brdo pod Belščico, $1200 \mathrm{~m}$; Begunjščica, $1000 \mathrm{~m}$; Uršlja gora, $1500 \mathrm{~m}$.

Mnium thomsonii Schimp. - bor-mont: Medvedjek, nad Podkorenom, 1000 m; Srednji vrh, nad Gozd Martuljkom, 1000 m; Hruški vrh, $1700 \mathrm{~m}$; Črni vrh nad Jesenicami, $1400 \mathrm{~m}$; Medji dol (Wallnöfer 1888); Medji dol, 1000 m; planina Pusti rovt pod Korenščico, 1500 m; Vajnež, 2100 m; Belščica (Paulin 1914); Debelo brdo pod Belščico, 1200 m (Martinčič 2004); Stol, 2000 m (Martinčič 2004); Begunjščica, $1000 \mathrm{~m}$; dolina Završnica, $800 \mathrm{~m}$; pod Ljubeljem, 950 m; Vranček pod Ljubeljem, $850 \mathrm{~m}$; Ljubelj, 1000 m; Jelendol, pod Penatco, 900 m; Spodnje Jezersko: Tisovec, $850 \mathrm{~m}$; dolina Topla, $800 \mathrm{~m}$; dolina Tržiške Bistrice (Glowacki 1912); Čadovlje pri Tržiču, 600 m; Dolžanova soteska pri vasi Dolina, $850 \mathrm{~m}$.

Myurella julacea (Schwägr.) Schimp. - subarkt-subalp: Krvavka, 1750 m (Martinčič 2004); Medji dol (Wallnöfer 1888); Stol, 2000 m; Lju- belj, $1100 \mathrm{~m}$; Olševa, Potočka zijalka, vhod, 1700 m; Uršlja gora, 1650 m; Uršlja gora, vzh. pobočje, 1100 m; grad Kamen, pri Begunjah (Glowacki 1912).

Myurella sibirica (Müll.-Hal.) Reim. - subarkt-subalp: Javorniški Rovt, 1100 m (Martinčič 2004); Beli potok pri Podljubelju (Glowacki 1912).

Neckera besseri (Lobarz.) Jur. - temp-subkont: dolina Topla, 800 m; Uršlja gora, 1320 m (Grom LJU, det. Martinčič; Martinčič 2012).

Neckera complanata (Hedw.) Hueb. - bor-temp: nad Gozd Martuljkom, 800 m; Gozdašnica, nad dolino Završnico, $800 \mathrm{~m}$; Vranček pod Ljubeljem, $850 \mathrm{~m}$; Spodnje Jezersko: Tisovec, $850 \mathrm{~m}$; Olševa, 1400 m (Kutnar et al. 2006, det. Martinčič); Javorje pod Malo Peco, 1400 m (Kutnar et al. 2006, det. Martinčič, Martinčič 2004); dolina Topla, $800 \mathrm{~m}$; nad Solčavo, levi breg reke Savinje, 700 m (Grom LJU 1970, det. Martinčič); Črna na Koroškem, breg reke Bistre, $620 \mathrm{~m}$ (Juvan 2008); Uršlja gora, 1320 m (Grom LJU 1959, det. Martinčič, Martinčič 2012); Uršlja gora (Wallnöfer 1888); Čadovlje pri Tržiču, 600 m; Javorniško sedlo (za Storžičem), 1400 m; Dolžanova soteska, pri vasi Dolina, $750 \mathrm{~m}$. Jelendol, 1350 m (Marinček \& Čarni 2007).

Neckera crispa Hedw. - temp: Uršlja gora (Wallnöfer 1888); Srednji vrh nad Gozd Martuljkom, 1000 m; Črni vrh nad Jesenicami, 1400 m; Medji dol, 1000 m; Debelo brdo pod Belščico, $1200 \mathrm{~m}$; pri Valvazorjevem domu pod Stolom, 1200 m; Begunjščica, 1000 m (Martinčič 2004); dolina Završnica, 800 m; Vranček pod Ljubeljem, 850 m; Jelendol pod Košuto (Grom LJU 1959); pod Pavličevim sedlom, pri kmetiji Covnik, $1200 \mathrm{~m}$; Javorje pod Malo Peco, $1320 \mathrm{~m}$ (Kutnar et al. 2006, det. Martinčič); Čofatijev vrh nad dolino Toplo (Piskernik 1977, det. Martinčič); dolina Topla, 800 m; nad Solčavo, levi breg reke Savinje, 700 m (Grom LJU 1970); Strevčev vrh pri Olševi, 1400 m; Uršlja gora (Pajnič LJU 1932, det. Martinčič); Uršlja gora: Kozarnica, 1000 m (Piskernik 1977, det. Martinčič); Draga pri Begunjah na Gorenjskem, 690 m; Podljubelj, 860 m (Grom LJU 1963); Čadovlje pri Tržiču, 600 m; Dolžanova soteska, pri vasi Dolina, $750 \mathrm{~m}$.

Neckera pennata Hedw. - temp: Medvodje pod Penatco, 850 m (LJU, Martinčič 2009); Jelendol, pod Penatco, $900 \mathrm{~m}$.

*Neckera pumila Hedw. - temp-subatl: Velika Golica, 1400 m; Stol, 2000 m; Jelendol, pod Penatco, $900 \mathrm{~m}$. 
*Oligotrichum hercynicum (Hedw.) Lam. \& DC. subarkt-subalp: Olševa: Zadnji travnik, $1400 \mathrm{~m}$.

Oncophorus virens (Hedw.) Brid. - subarkt-subalp: Velika Golica, 1800 m (Martinčič 2004); Stol, 2000 m (Martinčič 2004).

Orthothecium intricatum (Hartm.) Schimp. bor-mont: Dovška Baba, 1800 m; Velika Golica, 1800 m; Struška Kočna, 1600 m (Martinčič 2004); Stol, 2000 m (Martinčič 2004); Begunjščica, 2000 m; Olševa (Breidler 1891); Olševa: Potočka zijalka, vhod, $1700 \mathrm{~m}$; Beli potok pri Podljubelju (Glowacki 1912).

Orthothecium rufescens (Dicks. ex Brid.) Schimp. - bor-mont: Srednji vrh nad Gozd Martuljkom, $1000 \mathrm{~m}$; Klek, $1600 \mathrm{~m}$; Krvavka, $1750 \mathrm{~m}$; Sv. Križ pri Planini pod Golico, $1000 \mathrm{~m}$; Korenščica; Medji dol (Müllner 1893); Vajnež, $2100 \mathrm{~m}$; Stol, $2000 \mathrm{~m}$; Begunjščica, $1400 \mathrm{~m}$; Ljubelj, 1000 m; Olševa (Breidler 1891); Uršlja gora, $1650 \mathrm{~m}$; pod Javornikom (za Storžičem), $800 \mathrm{~m}$.

Orthotrichum affine Schrad. ex Brid. - temp: dolina Tržiške Bistrice (Glowacki 1912).

var. affine: Trebiže nad Ratečami, 1100 m; Lajb pod Ljubeljem, 750 m; Medvodje pod Penatco, 850 m; Jelendol, pod Penatco, 900 m; Koprivna, pri kmetiji Kumar, 1300 m; dolina Topla, nad Fajmutom, 1100 m; Plešivški mlin pod Uršljo goro, $900 \mathrm{~m}$; Čadovlje pri Tržiču, $600 \mathrm{~m}$.

Orthotrichum anomalum Hedw. - subtemp: nad Ratečami, $1000 \mathrm{~m}$; pod Pavličevim sedlom, pri kmetiji Covnik, 1200 m; Olševa (Breidler 1891); Sv. Duh pod Olševo, pri Potočniku, 1200 m; Uršlja gora, 1600 m; Uršlja gora, vzh. pobočje, $1100 \mathrm{~m}$; dolina Tržiške Bistrice (Glowacki 1912).

*Orthotrichum cupulatum Hoffm. ex Brid. var. cupulatum - temp: nad Dovjem, 800 m; dolina Završnica, 800 m; Uršlja gora, 1650 m; Čadovlje pri Tržiču, $600 \mathrm{~m}$.

*Orthotrichum diaphanum Schrad ex Brid. merid-temp: Podkoren, 850 m; Ljubelj, 1000 m; Zgornje Jezersko: pod Roblekom, 1000 m; pod Pavličevim sedlom, pri kmetiji Covnik, $1200 \mathrm{~m}$.

Orthotrichum lyellii Hook. \& Taylor - temp: Ljubelj, 1000 m (Martinčič 2009); pod Pavličevim sedlom, pri kmetiji Covnik, 1200 m.

*Orthotrichum obtusifolium Brid. - bor-temp: Podkoren, $850 \mathrm{~m}$; Koprivna, pri kmetiji $\mathrm{Ku}-$ mar, $1300 \mathrm{~m}$; Podgorje pri Slovenj Gradcu, $450 \mathrm{~m}$; Draga pri Begunjah na Gorenjskem, 690 m; Čadovlje pri Tržiču, 600 m.

*Orthotrichum pallens Bruch ex Brid. - subtemp:
Trebiže nad Ratečami, $1100 \mathrm{~m}$; Podkoren, $850 \mathrm{~m}$; Srednji vrh nad Gozd Martuljkom, 950 m; nad Dovjem, 800 m; med Hruško planino in Sv. Križem, $1100 \mathrm{~m}$; Medvodje pod Penatco, 850 m; Podgorje pri Slovenj Gradcu, $450 \mathrm{~m}$; Stolec nad Tržičem, $560 \mathrm{~m}$.

*Orthotrichum patens Bruch ex Brid. - temp-subkont: Draga pri Begunjah na Gorenjskem, $690 \mathrm{~m}$.

Orthotrichum pumilum Sw. ex anon. - temp: Uršlja gora: pobočje nad Ravnami (Glowacki 1908); nad Podkorenom, $950 \mathrm{~m}$; nad Dovjem, $800 \mathrm{~m}$; Lajb pod Ljubeljem, $750 \mathrm{~m}$; Črna na Koroškem (Wallnöfer 1888); Plešivški mlin pod Uršljo goro, $900 \mathrm{~m}$.

Orthotrichum rupestre Schleich. ex Schwägr. bor-temp: Hudičev most pri Tržiču (Glowacki 1912); dolina Tržiške Bistrice (Glowacki 1912). var. carinthiacum Glow.: dolina Tržiške Bistrice (Glowacki 1912); Dolina (Hudičev most) pri Tržiču (Glowacki 1912).

Orthotrichum speciosum Nees - bor-temp: Trebiže nad Ratečami, 1100 m; Srednji vrh nad Gozd Martuljkom, $950 \mathrm{~m}$; nad Dovjem, $800 \mathrm{~m}$; Jelendol, pod Penatco, $900 \mathrm{~m}$; pod Pavličevim sedlom, pri kmetiji Covnik, 1250 m; Koprivna, pri kmetiji Kumar, 1300 m; dolina Topla, nad Fajmutom, 1100 m; Uršlja gora, 1600 m; Smokuč pri Begunjah na Gorenjskem, 540 m; dolina Tržiške Bistrice (Glowacki 1912).

Orthotrichum stellatum Brid. - temp-subkont: Uršlja gora: pobočje nad Ravnami (Glowacki 1908).

*Orthotrichum stramineum Hornsch. ex Brid. temp: Rateče, $900 \mathrm{~m}$; Jelendol, pod Penatco, 900 m; Koprivna, pri kmetiji Kumar, 1300 m.

Orthotrichum striatum Hedw. - bor-temp: Trebiže nad Ratečami, 1100 m; Peč, 1100 m; nad Dovjem, $800 \mathrm{~m}$; pri Valvazorjevem domu pod Stolom, 1200 m; Ljubelj, Sv. Ana, 900 m; Lajb pod Ljubeljem, $750 \mathrm{~m}$; Medvodje pod Penatco, 850 m; Jelendol, pod Penatco, 900 m; Zgornje Jezersko: pod Roblekom, 1000 m; pod Pavličevim sedlom, pri kmetiji Covnik, 1200 m; dolina Koprivna, 1200 m; Koprivna, pri kmetiji Kumar, 1300 m; dolina Topla, nad Fajmutom, 1100 m; Plešivški mlin pod Uršljo goro, 900 m; Draga pri Begunjah na Gorenjskem, 690 m; Beli potok pri Tržiču (Glowacki 1912); dolina Tržiške Bistrice (Glowacki 1912).

*Oxyrrhynchium hians (Hedw.) Loeske - temp: Vranček pod Ljubeljem, $850 \mathrm{~m}$; Ljubelj, 1000 m; dolina Koprivna, 1300 m; Olševa: Po- 
točka zijalka, vhod, 1700 m; Strevčev vrh pri Olševi, nad Rogarjem, 1400 m.

*var. rigidum (Boulay) Düll: Plešivški mlin pod Uršljo goro, $900 \mathrm{~m}$.

*Oxyrrhynchium pumilum (Wils.) Loeske - subatl-submed: Plešivški mlin pod Uršljo goro, $900 \mathrm{~m}$.

*Oxyrrhynchium schleicheri (R. Hedw.) Röll. - merid-temp: nad Gozd Martuljkom, 800 m; nad Dovjem, $800 \mathrm{~m}$; planina Pusti rovt pod Korenščico, 1500 m; Stol, 1700 m; Begunjščica, $1000 \mathrm{~m}$; dolina Završnica, $800 \mathrm{~m}$; Ljubelj, $1000 \mathrm{~m}$; pod Pavličevim sedlom, pri kmetiji Covnik, $1200 \mathrm{~m}$; Olševa: Potočka zijalka, vhod, $1700 \mathrm{~m}$; Dolžanova soteska, pri vasi Dolina, $750 \mathrm{~m}$.

*Oxystegus tenuirostris (Hook. \& Taylor) A. J. E. Smith - bor-temp: nad Dovjem, $800 \mathrm{~m}$.

Palustriella commutata (Hedw.) Ochyra - bor-temp: Uršlja gora: graben Suhe (Glowacki 1908); Peč, $1250 \mathrm{~m}$; nad Podkorenom, $750 \mathrm{~m}$; Srednji vrh nad Gozd Martuljkom, 1000 m; Krvavka, 1750 m; Sv. Križ pri Planini pod Golico, 1000 m (Martinčič 2004); Hruška planina pod Rožco, 1200 m; Črni vrh nad Jesenicami, 1400 m; Klek, 1600 m; Medji dol, 1000 m; Javorniški Rovt, 1100 m; pri Valvazorjevem domu pod Stolom; Potoška planina pod Belščico, 1300 m; Debelo brdo pod Belščico, 1200 m; Begunjščica, 1000 m (LJU, Martinčič 2004); dolina Završnica, pod Begunjščico, $1000 \mathrm{~m}$; Stol, 2000 m; Jelendol, pod Penatco, 900 m; Lajb pod Ljubeljem, $750 \mathrm{~m}$; Zgornje Jezersko: pod Roblekom, $1000 \mathrm{~m}$; pod Pavličevim sedlom, pri kmetiji Covnik, 1200 m; Olševa (Breidler 1891); Črna na Koroškem (Wallnöfer 1888); Strevčev vrh pri Olševi, nad Rogarjem, 1400 m; Sv. Duh pod Olševo, pri Potočniku, 1200 m; Spodnji Razbor pri Mislinjski Dobravi, 500 m; Čadovlje pri Tržiču, $600 \mathrm{~m}$; pod Javorniškim sedlom (za Storžičem), $800 \mathrm{~m}$.

var. fluctuans (Bruch et al.) Ochyra - bor-temp: Medji dol, 1000 m (Martinčič 2004); dolina Završnica, pod Begunjščico, 1000 m.

var. sulcata (Lindb.) Ochyra - subarkt-subalp: Olševa (Breidler 1891).

Palustriella falcata (Brid.) Hedenäs - bor-temp: Uršlja gora: graben Suhe nad Ravnami (Glowacki 1908); Krvavka, 1000 m (Martinčič 2004); Hruška planina pod Rožco, 1200 m; planina Pusti rovt pod Korenščico, 1500 m; Medji dol, 1000 m; dolina Završnica, pod Begunjščico, 1000 m (Martinčič 2004).
Palustriella decipiens (De Not.) Ochyra - bor-mont: Krvavka, 1750 m; planina Pusti rovt pod Korenščico, 1500 m; Struška Kočna, 1600 m; Potoška planina pod Belščico, $1300 \mathrm{~m}$ (LJU, Martinčič 2009); Vajnež, 2100 m; Stol, 2000 m; Jelendol, $900 \mathrm{~m}$; Olševa: Zadnji travnik, 1400 m; dolina Topla, nad Fajmutom, 1100 m.

Paraleucobryum longifolium (Hedw.) Loeske bor-mont: Črni vrh nad Jesenicami; Medji dol, 1000 m; Javorniški Rovt, 1100 m; pri Valvazorjevem domu pod Stolom, 1200 m; dolina Završnica, pod Begunjščico, 1000 m; Begunjščica, 1000 m; Koprivna: Čofatijev vrh (Grom LJU 1960); dolina reke Bistre pri Črni na Koroškem (Wallnöfer 1888).

subsp. longifolium: pri Valvazorjevem domu pod Stolom, 1200 m (Martinčič 2004); dolina Završnica, pod Begunjščico, 1000 m (LJU, Martinčič 2004); Begunjščica, 2000 m; pod Pavličevim sedlom, pri kmetiji Covnik, 1200 m; dolina Koprivna, $950 \mathrm{~m}$.

Paraleucobryum sauteri (Bruch \& Schimp.) Loeske - temp-subkont: Krvavka, 1000 m (Martinčič 2004).

NT-Philonotis arnellii Husnot - temp: Vajnež, 2100 m; Stol, 2000 m (Martinčič 2004).

*VU-Philonotis caespitosa Jur. - bor-temp: pod Pavličevim sedlom, pri kmetiji Covnik, 1200 m; Strevčev vrh pri Olševi, nad Rogarjem, 1400 m.

Philonotis calcarea (Bruch \& Schimp.) Schimp. - bor-temp: Velika Golica, 1400 m; Medji dol, 1000 m (Martinčič 2004); pri Javorniku blizu Jesenic (Paulin, 1914); Javorniški Rovt, 1100 m; Zelenica (F. Plemelj LJU 1848); Begunjščica (Fr. Plemelj LJU 1848); dolina Završnica, pod Begunjščico, 1000 m (Martinčič 2004); pod Javorniškim sedlom (za Storžičem), $800 \mathrm{~m}$.

Philonotis fontana (Hedw.) Brid. - bor-temp: Črni Vrh, nad Jesenicami, 1400 m (Martinčič 2004); Klek, 1600 m; Medji dol (Müllner 1893); Belščica (F. Plemelj LJU 1848); Potoška planina pod Belščico; Stol (Müllner 1893); Zgornje Jezersko: pod Roblekom, 1000 m; Strevčev vrh pri Olševi, nad Rogarjem, $1400 \mathrm{~m}$.

Philonotis tomentella Molendo - arkt-alp: Peč, 1150 m; Olševa (Breidler 1891).

Plagiobryum zierii (Hedw.) Lindb. - subarkt-subalp: Medji dol (Müllner 1893); Stol, $2000 \mathrm{~m}$ (Martinčič 2009); Ljubelj, $1000 \mathrm{~m}$; dolina Tržiške Bistrice (Glowacki 1912); Beli potok pri Podljubelju (Glowacki 1912); Javorniško sedlo (za Storžičem), $1400 \mathrm{~m}$.

Plagiomnium affine (Bland. ex Funck) T. J. Kop. 
- temp: Potoška planina pod Belščico, 1300 m (Martinčič 2004); Olševa: Zadnji travnik, 1400 m; Olševa (Breidler 1891); dolina reke Bistre, $650 \mathrm{~m}$; Uršlja gora, $1400 \mathrm{~m}$.

Plagiomnium cuspidatum (Hedw.) T. J. Kop. bor-temp: Srednji vrh nad Gozd Martuljkom, 1000 m; nad Dovjem, 800 m; Javorniški Rovt (Martinčič 2004); Lajb pod Ljubeljem, 750 m; Jelendol, pod Penatco, $900 \mathrm{~m}$; dolina Koprivna, $1200 \mathrm{~m}$; Plešivški mlin pod Uršljo goro, 900 m; dolina Topla, 750 m; Strevčev vrh pri Olševi, nad Rogarjem, 1400 m; dolina reke Bistre, 650 m; Smokuč pri Begunjah na Gorenjskem, $540 \mathrm{~m}$; Čadovlje pri Tržiču, $600 \mathrm{~m}$.

Plagiomnium elatum (Bruch \& Schimp.) T. J. Kop. - bor-temp: med Gozd Martuljkom in Belco, $700 \mathrm{~m}$; Potoška planina pod Belščico, 1300 m (Martinčič 2004); dolina Završnica, $800 \mathrm{~m}$; Lajb pod Ljubeljem, $750 \mathrm{~m}$; Zgornje Jezersko: pod Roblekom, 1000 m; pod Pavličevim sedlom, pri kmetiji Covnik, 1200 m; Olševa: barje Zadnji travnik, 1340 m; dolina reke Bistre, 650 m; dolina Koprivna, 1200 m; dolina Topla, 750 m; Uršlja gora, 1400 m; Plešivški mlin pod Uršljo goro, $900 \mathrm{~m}$.

Plagiomnium ellipticum (Brid.) T. J. Kop. - bor-mont: med Gozd Martuljkom in Belco, 700 m; Srednji vrh nad Gozd Martuljkom, 1000 m; Klek, 1600 m (Martinčič 2004); Javorniški Rovt, 1100 m; Zgornje Jezersko: pod Roblekom, 1000 m; dolina Koprivna, ob reki Koprivni, 900 m; Sleme nad dolino Koprivno (Grom LJU 1964); Uršlja gora, 1500 m; Čadovlje pri Tržiču, $600 \mathrm{~m}$.

Plagiomnium medium (Bruch \& Schimp. ) T. J. Kop. - bor-mont: Rateče, 900 m; Hruška planina pod Rožco, 1200 m; Črni vrh nad Jesenicami, 1400 m; Hruška planina, 1200 m; Javorniški Rovt, 1100 m (Martinčič 2004); dolina Završnica, 800 m; dolina Koprivna, 950 m; dolina Topla, pod Burjakovim hribom, $800 \mathrm{~m}$; dolina Topla, nad Fajmutom, 1100 m; Uršlja gora, $1400 \mathrm{~m}$; Čadovlje pri Tržiču, $600 \mathrm{~m}$; pod Javorniškim sedlom (za Storžičem), $800 \mathrm{~m}$.

Plagiomnium rostratum (Schrad.) T. J. Kop. bor-temp: Uršlja gora (Glowacki 1908); Srednji vrh nad Gozd Martuljkom, 1000 m; Medji dol, 1000 m; Medji dol (Müllner 1893); planina Pusti rovt pod Korenščico, 1500 m (Martinčič 2004); Struška Kočna, 1600 m; Vajnež, 2100 m; pri Valvazorjevem domu pod Stolom, 1200 m; Begunjščica, 1000 m; Vranček pod Ljubeljem, $850 \mathrm{~m}$; Spodnje Jezersko: Tisovec, $850 \mathrm{~m}$;
Zgornje Jezersko: pod Roblekom, 1000 m; dolina Koprivna, 1200 m; Olševa: Zadnji travnik, 1400 m; Jazbina pri Žerjavu, 700 m (Piskernik 1977, det. Martinčič); dolina reke Bistre, 650 m; Uršlja gora, $1500 \mathrm{~m}$; Plešivški mlin pod Uršljo goro, $900 \mathrm{~m}$; Begunje na Gorenjskem (Müllner 1893); Draga pri Begunjah na Gorenjskem, 690 m; Čadovlje pri Tržiču, 600 m; Javorniško sedlo (za Storžičem), $1400 \mathrm{~m}$.

Plagiomnium undulatum (Hedw.) T. J. Kop. - temp: Rateče, 900 m; Sv. Križ pri Planini pod Golico (Dolšak LJU 1938); Sv. Križ, pri Planini pod Golico, $1000 \mathrm{~m}$; Velika Golica, 1400 m; Medji dol (Müllner 1893); planina Pusti rovt pod Korenščico, 1500 m; Javornik pri Jesenicah (Plemelj V. LJU 1873); Begunjščica, 1000 m; Lajb pod Ljubeljem, ob potoku Mošenik, 750 m; Zgornje Jezersko: pod Roblekom, $1000 \mathrm{~m}$; pod Pavličevim sedlom, pri kmetiji Covnik, 1200 m; dolina Koprivna, 1200 m; dolina Topla, nad Fajmutom, 1100 m; dolina Topla, 750 m; Strevčev vrh pri Olševi, 1400 m; dolina reke Bistre, $650 \mathrm{~m}$; Plešivec (Piskernik 1977, det. Martinčič); Zgornji Razbor, 700 m; Draga pri Begunjah na Gorenjskem, 690 m; Jelendol, pri gradu Puterhof (Košir 2002).

Plagiopus oederianus (Sw.) H. A. Crum \& L. E. Anderson - bor-mont: Gozd Martuljek (Fabiani LJU 1929); Sv. Križ pri Planini pod Golico, 1000 m; Sv. Križ pri Planini pod Golico (Müllner 1893); Črni vrh nad Jesenicami, 1400 m; Velika Golica, 1800 m; Medji dol, 1000 m; Belščica (Paulin 1914); Stol (Dolšak LJU 1920); Begunjščica, $2000 \mathrm{~m}$; pod Ljubeljem, $950 \mathrm{~m}$; Najbrževo pod Malo Peco, 1400 m (Kutnar et al. 2006, det. Martinčič); Uršlja gora, 1600 m; Beli potok pri Podljubelju (Glowacki 1912).

*Plagiothecium cavifolium (Brid.) Z. Iwats. bor-mont: Peč, pri planinskem domu Tromeja, 1200 m; Korensko sedlo, 1600 m; Krvavka, $1600 \mathrm{~m}$; Spodnje Jezersko: Tisovec, $850 \mathrm{~m}$; dolina Topla, pri Florinu, $900 \mathrm{~m}$; Čadovlje pri Tržiču, $600 \mathrm{~m}$.

*Plagiothecium curvifolium Schlieph. ex Limpr. - temp: Peč, pri planinskem domu Tromeja, $1200 \mathrm{~m}$; Belca, $1350 \mathrm{~m}$ (leg. Zupančič); Spodnje Jezersko: Tisovec, $850 \mathrm{~m}$; pod Pavličevim sedlom, pri kmetiji Covnik, 1200 m; Strevčev vrh pri Olševi, nad Rogarjem, 1400 m; Uršlja gora, $1600 \mathrm{~m}$.

Plagiothecium denticulatum (Hedw.) Schimp. bor-temp: Peč, pri planinskem domu Tromeja, 1200 m; Korensko sedlo, 1060 m; Črni vrh nad 
Jesenicami, 1400 m; med Hruško planino in Sv. Križem pri Planini pod Golico, 1100 m; Velika Golica, 1400 m; pri Valvazorjevem domu pod Stolom, $1200 \mathrm{~m}$; dolina Završnica, $800 \mathrm{~m}$; Vranček pod Ljubeljem, $850 \mathrm{~m}$; pod Pavličevim sedlom, pri kmetiji Covnik, 1200 m; dolina Koprivna, 1200 m; pod Uršljo goro, 1190 m (Marinček \& Čarni 2007); Uršlja gora, 1500 m; Javorniško sedlo (za Storžičem), 1400 m; Jelendol, 1350 m (Marinček \& Čarni 2007).

*var. obtusifolium (Turner) Moore: dolina Koprivna, ob reki Koprivni, $900 \mathrm{~m}$; dolina Topla, nad Fajmutom, 1100 m; dolina reke Bistre, $650 \mathrm{~m}$.

Plagiothecium laetum Schimp. - bor-mont: Peč, pri planinskem domu Tromeja, $1200 \mathrm{~m}$; Belca (Martinčič 2004); Krvavka, 1600 m; Struška Kočna, 1600 m; Javorniški Rovt, 800 m; Debelo brdo pod Belščico, 1200 m; Begunjščica, 1900 m; Begunjščica, nad Poljško planino, 1300 m; dolina Završnica, 800 m; Vranček pod Ljubeljem, 850 m; Spodnje Jezersko: Tisovec, $850 \mathrm{~m}$; pod Pavličevim sedlom, pri kmetiji Covnik, 1200 m; Olševa, sev. pobočje, $1300 \mathrm{~m}$ (Martinčič 2003); Olševa, $1400 \mathrm{~m}$ (Kutnar et al. 2006, det. Martinčič); Mozganov vrh, 590 m (Piskernik 1977, det. Martinčič); dolina Koprivna, 900 m, 1300 m; dolina reke Bistre, 650 m; Najbrževo pod Malo Peco, 1400 m (Kutnar et al. 2006, det. Martinčič); dolina Topla, pod Peco (Piskernik 1977, det. Martinčič); Čofatijev vrh (Piskernik 1977, det. Martinčič); dolina Topla, pri Florinu, 900 m; Strevčev vrh pri Olševi, nad Rogarjem, 1400 m; Jazbina pri Žerjavu, 1000 m (Piskernik 1977, det. Martinčič); Ludranski vrh: Podgora (Grom LJU 1960); dolina reke Bistre, 650 m; Uršlja gora, 1400 m; Bačovski vrh, 1000 m; Zgornji Razbor, 700 m.

Plagiothecium nemorale (Mitt.) A. Jaeger - temp: Peč, pri planinskem domu Tromeja, $1200 \mathrm{~m}$; Medvedjek nad Podkorenom, 1000 m; Uršlja gora (Wallnöfer 1888); Sv. Križ pri Planini pod Golico, 1000 m; Črni vrh nad Jesenicami, 1400 m; Javorniški Rovt, 1100 m; Košuta: planina Kofce, $1300 \mathrm{~m}$ (Piskernik 1977, det. Martinčič); Spodnje Jezersko: Tisovec, $850 \mathrm{~m}$; dolina Koprivna, ob reki Koprivni, 900 m; Čofatijev vrh (Piskernik 1977, det. Martinčič); dolina Topla, $750 \mathrm{~m}$; dolina reke Bistre, $650 \mathrm{~m}$; Uršlja gora, $1300 \mathrm{~m}$ (Piskernik 1977, det. Martinčič); Uršlja gora, 1500 m; Čadovlje pri Tržiču, 600 m; Javorniško sedlo (za Storžičem), $1400 \mathrm{~m}$.
*Plagiothecium succulentum (Wilson) Lindb. bor-temp: dolina reke Bistre, $650 \mathrm{~m}$; Javorniško sedlo (za Storžičem), $1400 \mathrm{~m}$.

Plagiothecium undulatum (Hedw.) Schimp. bor-temp: Velika Golica, 1400 m; Javorniški Rovt, 1100 m; Košuta: planina Kofce, 1300 m (Piskernik 1977, det. Martinčič); Jelendol, pod Košuto; Jelendol, pod Košuto (Grom LJU 1959); Sv. Duh pod Olševo (Grom LJU 1970); pod Pavličevim sedlom (Grom LJU 1970); pod Pavličevim sedlom, pri kmetiji Covnik, 1200 m; dolina Koprivna, 500 m (Piskernik 1977, det. Martinčič); Sleme nad dolino Koprivno (Grom LJU 1964); Olševa, sev. pobočje, $1300 \mathrm{~m}$; Olševa, 1400 m (Kutnar et al. 2006, det. Martinčič); dolina Topla, nad Fajmutom, 1400 m; pod Olševo, 1290 m (Grom LJU 1970); Strevčev vrh pri Olševi, nad Rogarjem, 1400 m; Ludranski vrh (Grom LJU 1960); Zgornje Jezersko: pod Roblekom, 1000 m; Zgornji Razbor, 700 m; Javornik nad Tržičem (Dolšak LJU 1921); Javorniško sedlo (za Storžičem), $1400 \mathrm{~m}$.

Plasteurhynchium striatulum (Spruce) M. Fleisch. - merid-temp: dolina Koprivna (Wraber M. 1963).

Platydyctia jungermannioides (Brid.) Crum - subarkt-subalp: Uršlja gora: pobočje nad Ravnami (Glowacki 1908). Begunjščica, 2000 m; Beli potok pri Podljubelju (Glowacki 1912).

*Platygyrium repens (Brid.) Schimp. - temp: Rateče, $900 \mathrm{~m}$; Podkoren, $850 \mathrm{~m}$; nad Dovjem, $800 \mathrm{~m}$.

Platyhypnidium riparioides (Hedw.) Dixon temp: Črni vrh nad Jesenicami, 1400 m; Velika Golica, 1400 m; Medji dol, ob potoku Javornik, $1000 \mathrm{~m}$; dolina Završnica, pod Begunjščico, 1000 m; Jelendol, pod Penatco, 900 m; v potoku Mošenik pri Podljubelju; dolina Koprivna, $1200 \mathrm{~m}$; dolina Topla, pri Florinu, $900 \mathrm{~m}$; dolina Topla, 750 m; Olševa, juž. pobočje, 800 m; dolina reke Bistre pri Črni na Koroškem (Wallnöfer 1888); Javorjev potok pri Črni na Koroškem (Wallnöfer 1888); v Tržiški Bistrici; Čadovlje pri Tržiču, $600 \mathrm{~m}$.

Pleurozium schreberi (Willd. ex Brid.) Mitt. - bor-temp: Belščica (Paulin 1914); Gozdašnica, nad dolino Završnico, 800 m; Begunjščica, 1000 m; Ljubelj: Sv. Ana, $900 \mathrm{~m}$; Spodnje Jezersko: Tisovec, 850 m; Zgornje Jezersko: pod Roblekom, 1000 m; Olševa: Zadnji travnik, $1400 \mathrm{~m}$; Olševa - sev. pobočje, 1300 m; Olševa, vzhodni rob (Grom LJU 1970); dolina Topla, nad Fajmutom, 1400 m; nad Solčavo, levi breg reke Sa- 
vinje (Grom LJU 1970); Ludranski vrh (Grom LJU 1960); Uršlja gora, $1300 \mathrm{~m}$ (Piskernik 1977, det. Martinčič); Uršlja gora: Kozakinovo; Graška Gora nad Velenjem (Grom LJU 1965); Draga pri Begunjah na Gorenjskem, $690 \mathrm{~m}$.

Pogonatum aloides (Hedw.) P. Beauv. - bor-temp: Peč, pri planinskem domu Tromeja, $1200 \mathrm{~m}$; pri Valvazorjevem domu pod Stolom, 1200 m; Javornik pri Jesenicah (Plemelj V. LJU 1873); Javorniški Rovt, 1100 m (Martinčič 2004); Begunjščica, nad Poljško planino, $1500 \mathrm{~m}$; Spodnje Jezersko: Tisovec, $850 \mathrm{~m}$ (Martinčič 2004); dolina Koprivna, 950 m; Olševa: Zadnji travnik, $1400 \mathrm{~m}$; dolina Topla, pod Burjakovim hribom, $700 \mathrm{~m}$; Strevčev vrh pri Olševi, nad Rogarjem, 1400 m; Bačovski vrh, 1000 m; pod Javorniškim sedlom (za Storžičem), 800 m.

Pogonatum nanum (Hedw.) P. Beauv. - temp: pri Črni na Koroškem, proti Javorju, 650 m (Martinčič 2012).

Pogonatum urnigerum (Hedw.) P. Beauv. - bor-mont: Klek, $1600 \mathrm{~m}$; Velika Golica, $1400 \mathrm{~m}$ (Martinčič 2004); Sv. Križ pri Planini pod Golico, $1000 \mathrm{~m}$; planina Svečica nad Javornikom (Plemelj V. LJU 1873); Belska planina nad Javornikom (Plemelj V. LJU 1873); Begunjščica, nad Poljško planino, $1500 \mathrm{~m}$; Olševa: Zadnji travnik, $1400 \mathrm{~m}$; dolina Topla, pod Burjakovim hribom, 700 m; dolina Topla, nad Fajmutom, 1400 m; Strevčev vrh pri Olševi, nad Rogarjem, 1400 m; pri Črni na Koroškem, proti Javorju, 650 m; Bačovski vrh, 1000 m; pod Javorniškim sedlom (za Storžičem), $800 \mathrm{~m}$.

Pohlia cruda (Hedw.) Lindb. - bor-temp: Peč, pri planinskem domu Tromeja, 1200 m; Uršlja gora (Wallnöfer 1888); Krvavka, 1750 m; Črni vrh nad Jesenicami, $1360 \mathrm{~m}$ (leg. Piskernik); Španov vrh nad Jesenicami, $1350 \mathrm{~m}$ (leg. Piskernik); Korenščica, 1500 m; Stol, 2000 m; Begunjščica, 2000 m; Strevčev vrh pri Olševi, nad Rogarjem, $1400 \mathrm{~m}$; dolina reke Bistre, $650 \mathrm{~m}$.

Pohlia elongata Hedw. - bor-mont: Medji dol, 1000 m; Javorniški Rovt, 1100 m (Martinčič 2004); pri Valvazorjevem domu pod Stolom, $1200 \mathrm{~m}$; med Javornikom (Jesenice) in Javorniškim Rovtom, $800 \mathrm{~m}$.

Pohlia nutans (Hedw.) Lindb. - subbor: Peč, pri planinskem domu Tromeja, $1200 \mathrm{~m}$; Begunjščica, 1000 m; Zelenica (Müllner 1893); dolina Koprivna, 950 m; dolina Topla, pod Burjakovim hribom, $700 \mathrm{~m}$.

Pohlia melanodon (Brid.) A.J. Shaw - temp: Medji dol (Müllner 1893).
*Pohlia wahlenbergii (F. Weber \& D. Mohr) A. L. Andrews - subbor: Spodnje Jezersko: Tisovec, 850 m; Olševa: pod Potočko zijalko, 1600 m; Uršlja gora, $1600 \mathrm{~m}$.

Polytrichastrum alpinum (Hedw.) G. L. Sm. - subarkt-subalp: Velika Golica, 1800 m; Sv. Križ pri Planini pod Golico, 1000 m; Medji dol (Müllner 1893); Belščica (Paulin 1914); pri Valvazorjevem domu pod Stolom, 1200 m; Begunjščica, 2000 m; dolina Koprivna (Piskernik 1977, det. Martinčič); Bačovski vrh, 1000 m; pod Javorniškim sedlom (za Storžičem), 800 m.

Polytrichastrum formosum (Hedw.) G.L. Sm. bor-temp: Petelinjek nad Korenskim sedlom, $1425 \mathrm{~m}$ (leg. Zupančič); Peč, pri planinskem domu Tromeja, 1200 m; Bavha nad Podkorenom (Piskernik 1977, det. Martinčič); Medvedjek nad Podkorenom, 1000 m; nad Gozd Martuljkom, 800 m; Kališe pri Dovjem (Piskernik 1977, det. Martinčič); med Hruško planino in Sv. Križem pri Planini pod Golico, 1100 m; Črni vrh nad Jesenicami (Piskernik 1977, det. Martinčič); Črni vrh nad Jesenicami (LJU, Martinčič 1977); Korenščica, 1500 m; Velika Golica, 1400 m; Struška Kočna, 1600 m; Potoška planina pod Belščico, 1300 m; Javornik pri Jesenicah (Plemelj V. LJU 1973, det. Glow.); pri Valvazorjevem domu pod Stolom, 1200 m; Debelo brdo pod Belščico, 1200 m; Vajnež, 2100 m; Javorniški Rovt, 1100 m; Stol (Müllner 1893); Begunjščica, nad Poljško planino, $1500 \mathrm{~m}$; Begunjščica, 920-1045 m (Piskernik 1971); Košuta: planina Kofce, 1300 m (Piskernik 1977, det. Martinčič); Jelendol, pod Penatco, 9oo m; Spodnje Jezersko: Tisovec, $850 \mathrm{~m}$; dolina Topla, nad Fajmutom, 1400 m; pod Pavličevim sedlom, pri kmetiji Covnik, 1200 m; Olševa, sev. pobočje, $1300 \mathrm{~m}$; Olševa, $1400 \mathrm{~m}$ (Kutnar et al. 2006, det. Martinčič); dolina Koprivna, 1000 m (Piskernik 1977, det. Martinčič); dolina Koprivna, 1200 m; Čofatija, nad Mežiško dolino, 1270 m (Grom LJU 1964); Knežji vrh (Piskernik 1977, det. Martinčič); Javorje pod Malo Peco, 1320 m (Kutnar et al. 2006, det. Martinčič); dolina Topla, pod Burjakovim hribom, 700 m; dolina Topla, pod Florinom, 850 m; pod Olševo, 1120 m (Grom LJU 1970); Strevčev vrh pri Olševi, nad Rogarjem, 1400 m; dolina reke Bistre, $650 \mathrm{~m}$; pri Črni na Koroškem, proti Javorju, 650 m; Uršlja gora, 1500 m; Bačovski vrh, 1000 m; Zgornji Razbor, 700 m; Graška gora nad Velenjem (Piskernik 1977, det. Martinčič); Draga pri Begunjah na Gorenjskem, 750 m (Pi- 
skernik 1977, det. Martinčič); Draga pri Begunjah na Gorenjskem, 690 m; Javorniško sedlo (za Storžičem), 1400 m; Jelendol, 1350 m (Marinček \& Čarni 2007).

Polytrichum commune Hedw. subsp. commune - subbor: Hruška planina pod Rožco, 1200 m (Martinčič 2004); Klek, 1600 m; pod Pavličevim sedlom, barje pri kmetiji Covnik, 1150 m; pod Javorniškim sedlom (za Storžičem), $800 \mathrm{~m}$.

Polytrichum juniperinum Hedw. - bor-temp: med Hruško planino in Sv. Križem pri Planini pod Golico, 1000 m; Velika Golica, 1400 m (Martinčič 2004); Klek, 1600 m; Hruški vrh, 1700 m; Struška Kočna, 1600 m; Pristava pri Javorniku (F. Plemelj LJU 1848); Vajnež, 2100 m; Begunjščica, 2000 m; Stol, 2000 m; Olševa: barje Zadnji travnik, 1340 m (Martinčič 2004); Uršlja gora, 1300 m (Piskernik 1977, det. Martinčič).

Polytrichum piliferum Hedw. - bor-temp: Črni vrh, nad Jesenicami (Tomažič LJU 1928).

Polytrichum strictum Menzies ex Brid. - bor-temp: barje pod Pavličevim sedlom, 1150 m ( Kutnar \& Martinčič 2002); Olševa: barje Zadnji travnik, 1340 m (Piskernik \& Martinčič 1970).

*VU-Polytrichum uliginosum (Wallr.) Schiebl - subbor: pod Pavličevim sedlom, pri kmetiji Covnik, $1200 \mathrm{~m}$.

NT-Pseudocalliergon trifarium (F. Weber \& D. Mohr) Loeske - subarkt-subalp: Kot pri Prevaljah (Zelnik et al. 2010).

Pseudoleskea incurvata (Hedw.) Loeske - bor-mont: Klek, 1600 m; Krvavka, 1750 m; Korenščica, 1500 m; Medji dol, 1000 m; Debelo brdo pod Belščico, 1200 m; Belščica (Paulin 1914); Stol, 2000 m; Begunjščica, 2000 m; Begunjščica, nad Poljško planino, $1500 \mathrm{~m}$; dolina Završnica, pod Begunjščico, 1000 m; Olševa: Zadnji travnik, $1400 \mathrm{~m}$; Javorje pod Malo Peco, 1320 m (Kutnar et al. 2006, det. Martinčič); Uršlja gora (Wallnöfer 1888).

Pseudoleskea radicosa (Mitt.) Macoun \& Kindb. var. denudata (Lindb.) Wijk \& Margad. - subarkt-subalp: Struška Kočna, 1600 m (Martinčič 2004); Stol, 2000 m (Martinčič 2004); Begunjščica, $2000 \mathrm{~m}$.

Pseudoleskeella catenulata (Brid. ex Schrad.) Kindb. - bor-mont: Uršlja gora: pobočje nad Ravnami (Glowacki 1908); Rateče, 900 m; nad Dovjem, 800 m; Sv. Križ pri Planini pod Golico, 1000 m (Martinčič 2004); Krvavka, 1000 m, 1700 m; Vajnež, 2100 m; Gozdašnica nad dolino Završnico, $800 \mathrm{~m}$; dolina Završnica, pod Begunjščico, 1000 m; Begunjščica, nad Poljško planino, 1500 m; Stol, 2000 m; Ljubelj: Sv. Ana, 900 m; Vranček pod Ljubeljem, 850 m; Javorje pod Malo Peco, 1320 m (Kutnar et al. 2006, det. Martinčič); Sv. Duh pod Olševo, pri Potočniku, 1200 m; Olševa, juž. pobočje, 800 m; Jazbina pri Žerjavu, 680 m (Piskernik 1977, det. Martinčič); Uršlja gora, 1650 m; Draga pri Begunjah na Gorenjskem, 690 m; dolina Tržiške Bistrice (Glowacki 1912); Čadovlje pri Tržiču, 600 m.

Pseudoleskeella nervosa (Brid.) Nyholm - bor-mont: na Trebižah nad Ratečami, 1100 m; Peč, pri planinskem domu Tromeja, $1200 \mathrm{~m}$; Rateče, 900 m; Uršlja gora: nad Ravnami (Suanjak 2002, leg. et det. Glowacki); Podkoren, 850 m; Srednji vrh nad Gozd Martuljkom, 950 m; nad Dovjem, $800 \mathrm{~m}$; planina Pusti rovt pod Korenščico, $1500 \mathrm{~m}$; Belščica (Paulin 1914); Begunjščica, $1000 \mathrm{~m}$; Begunjščica, zah. pobočje, 1500 m; Lajb pod Ljubeljem, 750 m; Vranček pod Ljubeljem, $950 \mathrm{~m}$; Koprivna, pri kmetiji Kumar, 1300 m; dolina Meže (Wallnöfer 1888); Javorje pod Malo Peco, 1320 m (Kutnar et al. 2006, det. Martinčič); Jazbina pri Žerjavu, 680 m (Piskernik 1977, det. Martinčič); Uršlja gora: pri kmetiji Plešivec, $950 \mathrm{~m}$; Uršlja gora, 1600 m; Uršlja gora (Wallnöfer 1888); Smokuč pri Begunjah na Gorenjskem, 540 m; Čadovlje pri Tržiču, $600 \mathrm{~m}$.

Pseudoleskeella tectorum (Funck ex Brid.) Kindb. ex Broth. - bor-temp: Mozganov vrh, $590 \mathrm{~m}$ (Piskernik 1977, det. Martinčič).

Pseudoscleropodium purum (Hedw.) M. Fleisch. temp: med Gozd Martuljkom in Belco, $700 \mathrm{~m}$; Javorniški Rovt, 1100 m; Gozdašnica nad dolino Završnico, 800 m; dolina Završnica, 800 m; dolina Topla, nad Fajmutom, 1100 m; Olševa, južno pobočje, $800 \mathrm{~m}$; Ludranski vrh (Grom LJU 1960); Uršlja gora; Uršlja gora: Kozarinovo; Bačovski vrh, 1000 m; Vrhe pri Slovenj Gradcu, Kozji hrbet, 550 m (Dakskobler et al. 2012); Draga pri Begunjah na Gorenjskem, $690 \mathrm{~m}$.

Pseudotaxiphyllum elegans (Brid.) Z. Iwats. - bor-temp: Sv. Križ pri Planini pod Golico, 1000 m; Begunjščica, nad Poljško planino, $1400 \mathrm{~m}$; Olševa, sev. pobočje, $1300 \mathrm{~m}$; dolina Topla, pod Peco (Piskernik 1977, det. Martinčič); dolina Topla, pri Florinu, $900 \mathrm{~m}$; dolina Topla pod Burjakovim hribom, 700 m; pri Črni na Koroškem, proti Javorju, $650 \mathrm{~m}$; dolina reke Bistre, $650 \mathrm{~m}$.

Pterigynandrum filiforme Hedw. - bor-mont: Peč, pri planinskem domu Tromeja, $1200 \mathrm{~m}$; Srednji vrh nad Gozd Martuljkom, 950 m; nad Dovjem, 800 m; Hruški vrh, 1700 m; med Hruško 
planino in Sv. Križem pri Planini pod Golico, 1100 m; Javorniški Rovt, 1100 m; Korenščica, 1500 m; Debelo brdo pod Belščico, 1200 m; Potoška planina pod Belščico, $1300 \mathrm{~m}$; Begunjščica, nad Poljško planino, $1500 \mathrm{~m}$; Stol, $2000 \mathrm{~m}$; pod Ljubeljem, $950 \mathrm{~m}$; Ljubelj, $1000 \mathrm{~m}$; Jelendol, pod Penatco, 900 m; Medvodje pod Penatco, $850 \mathrm{~m}$; pod Pavličevim sedlom, pri kmetiji Covnik, $1200 \mathrm{~m}$; Koprivna: Mozganov vrh; Javorje pod Malo Peco, 1320 m (Kutnar et al. 2006, det. Martinčič); Olševa: pod Potočko zijalko, $1600 \mathrm{~m}$; dolina Javorjevega potoka pri Črni na Koroškem (Wallnöfer 1888); Uršlja gora: Kozarnica, 1000 m (Piskernik 1977, det. Martinčič); Uršlja gora: pri kmetiji Plešivec, 950 m; Uršlja gora, 1600 m; Smokuč pri Begunjah na Gorenjskem, 540 m; Draga pri Begunjah na Gorenjskem, 690 m; Podljubelj, 1000 m (Grom LJU 1963); Čadovlje pri Tržiču, $600 \mathrm{~m}$; Dolžanova soteska, pri vasi Dolina, $750 \mathrm{~m}$; Javorniško sedlo (za Storžičem), 1400 m; Javornik nad Tržičem (Dolšak LJU 1921).

var. majus (De Not.) De Not.: Peč, pri planinskem domu Tromeja, 1200 m; Debelo Brdo pod Belščico, 1200 m (Martinčič 2004).

Ptilium crista - castrensis (Hedw.) De Not. bor-mont: Uršlja gora: Kozarinovo (Martinčič 1976).

Ptychodium plicatum (Schleich. ex F. Weber \& D. Mohr) Schimp. - subarkt-subalp: nad Gozd Martuljkom, 800 m; Dovška Baba, 1800 m (Martinčič 2004); Krvavka, 1600 m; Hruški vrh, 1700 m (LJU, Martinčič 2004); Velika Golica, 1800 m; Struška Kočna, 1600 m; Vajnež, 2100 m; Belščica (Paulin 1914); Begunjščica, 2000 m; Stol, 2000 m; Olševa, sev. pobočje, 1300 m; Olševa (Breidler 1891).

Pylaisia polyantha (Hedw.) Schimp. - subtemp: Mežica (Wallnöfer 1888); nad Gozd Martuljkom, 800 m; nad Dovjem, 800 m; Lajb pod Ljubeljem, 750 m; Jelendol, pod Penatco, 900 m; Črna na Koroškem (Wallnöfer 1888); Podgorje pri Slovenj Gradcu, 450 m; Zgornji Razbor, 700 m; Čadovlje pri Tržiču, 600 m.

*VU-Racomitrium aciculare (Brid ex Schrad.) Brid. - bor-temp: pod Pavličevim sedlom, pri kmetiji Covnik, $1200 \mathrm{~m}$.

*Racomitrium affine (F. Weber \& D. Mohr) Lindb. - temp: dolina Topla, pod Burjakovim hribom, $700 \mathrm{~m}$.

NT-Racomitrium aquaticum (Schrad.) Brid. temp: dolina Koprivna, 950 m; Javornik (za Storžičem) (Deschmann 1869).
Racomitrium canescens (Hedw.) Brid. - bor-mont: Sv. Križ pri Planini pod Golico (Müllner 1893); Velika Golica (Dolšak LJU 1938); Hruški vrh, 1700 m.

*Racomitrium ericoides (Brid.) Brid. - subbor: pod Hruško planino, 1300 m; Strevčev vrh pri Olševi, nad Rogarjem, 1400 m; pod Javornikom (za Storžičem), $800 \mathrm{~m}$.

*DD-Racomitrium microcarpon (Hedw.) Brid. bor-mont: dolina Koprivna, $950 \mathrm{~m}$.

Rhabdoweisia fugax (Hedw.) Bruch \& Schimp. bor-mont: dolina Koprivna, 950 m (LJU, Martinčič 2012); dolina Topla, pod Burjakovim hribom, $700 \mathrm{~m}$.

VU-Rhizomnium magnifolium (Horik.) T.J. Kop. - bor-mont: Sleme nad dolino Koprivno, $1200 \mathrm{~m}$ (Grom LJU, leg. M. Wraber; Martinčič 2003a).

Rhizomnium punctatum (Hedw.) T.J. Kop. bor-temp: Peč, pri planinskem domu Tromeja, $1200 \mathrm{~m}$; Srednji vrh nad Gozd Martuljkom, 1000 m; Velika Golica, 1400 m; Hruška planina pod Rožco, 1200 m; Sv. Križ pri Planini pod Golico, 1000 m; Črni vrh nad Jesenicami, $1400 \mathrm{~m}$; planina Pusti rovt pod Korenščico, 1500 m; Medji dol, 1000 m; Javorniški Rovt, 1100 m; Potoška planina pod Belščico, 1300 m; dolina Završnica, pod Begunjščico, $1000 \mathrm{~m}$; Begunjščica, 1000 m; Begunjščica, nad Poljško planino, 1500 m; Jelendol, pod Penatco, 900 m; Jelendol pod Košuto (Grom LJU 1959); Zgornje Jezersko: pod Roblekom, 1000 m; Olševa: barje Zadnji travnik, 1340 m; pod Pavličevim sedlom, pri kmetiji Covnik, $1200 \mathrm{~m}$; dolina Koprivna, 1200 m; Najbrževo pod Malo Peco, $1400 \mathrm{~m}$ (Kutnar et al. 2006, det. Martinčič); dolina Topla, nad Fajmutom, 1400 m; dolina Topla, pod Burjakovim hribom, $800 \mathrm{~m}$; Olševa; Strevčev vrh pri Olševi, nad Rogarjem, 1400 m; pri Črni na Koroškem, proti Javorju, 650 m; Ludranski vrh: Podgora (Grom LJU 1960); dolina reke Bistre, $650 \mathrm{~m}$; Uršlja gora, 1300 m (Piskernik 1977, det. Martinčič); Uršlja gora: Kozarnica, 1000 m (Piskernik 1977, det. Martinčič); Ljubelj, 1000 m; Zgornji Razbor, 700 m; Čadovlje pri Tržiču, 600 m; Jelendol, 1350 m (Marinček \& Čarni 2007).

Rhodobryum roseum (Hedw.) Limpr. - bor-temp: pod Pavličevim sedlom, pri kmetiji Covnik, 1200 m; Olševa: Zadnji travnik, 1400 m.

Rhynchostegium murale (Hedw.) Schimp. - temp: Peč, pri planinskem domu Tromeja, $1200 \mathrm{~m}$; Srednji vrh nad Gozd Martuljkom, 1000 m; nad Gozd Martuljkom, 800 m; nad Podkorenom, 
950 m; med Gozd Martuljkom in Belco, 700 m; dolina Belce, 860 m (Grom LJU 1965, det. Martinčič); nad Dovjem, $800 \mathrm{~m}$; Klek, $1600 \mathrm{~m}$; Črni vrh nad Jesenicami, $1400 \mathrm{~m}$; Velika Golica, 1400 m; Krvavka, 1400 m; Vajnež, 2100 m; Medji dol, 1000 m; Javorniški Rovt, 1100 m; pri Valvazorjevem domu pod Stolom, 1200 m; med Javornikom (Jesenice) in Javorniškim Rovtom, 700 m; Begunjščica, 1000 m; dolina Završnica: Žingarica, 800 m; Podljubelj, 700 m; Vranček pod Ljubeljem, 850 m; Ljubelj, 1000 m; Spodnje Jezersko: Tisovec, $850 \mathrm{~m}$; pod Pavličevim sedlom, pri kmetiji Covnik, $1200 \mathrm{~m}$; dolina Topla, nad Fajmutom, 1100 m; Olševa, sev. pobočje, 1300 m; Olševa: Zadnji travnik, $1400 \mathrm{~m}$; Sv. Duh pod Olševo, pri Potočniku, 1200 m; Uršlja gora, 1300 m (Piskernik 1977, det. Martinčič); Uršlja gora: Kozarnica, $1150 \mathrm{~m}$ (Grom LJU 1958, det. Martinčič); Uršlja gora: Kozarnica, 1000 m (Piskernik 1977, det. Martinčič); Uršlja gora, 1400 m; Draga pri Begunjah na Gorenjskem, 690 m (L-1976); dolina Tržiške Bistrice (Glowacki 1912); Dolžanova soteska, pri vasi Dolina, $750 \mathrm{~m}$; pod Javorniškim sedlom (za Storžičem), $800 \mathrm{~m}$.

Rhytidiadelphus loreus (Hedw.) Warnst. - bor-temp: Sv. Križ pri Planini pod Golico, 1000 m; Korenščica, 1500 m; Jelendol, pod Košuto; Sv. Duh pod Olševo (Grom LJU 1970); Olševa, sev. pobočje, $1300 \mathrm{~m}$; Olševa, $1400 \mathrm{~m}$ (Kutnar et al. 2006, det. Martinčič); dolina reke Bistre, 650 m; dolina Koprivna, 950 m; dolina Koprivna, 500 m (Piskernik 1977, det. Martinčič); Peca, 1500 m (Piskernik 1977, det. Martinčič); dolina Topla, nad Fajmutom, 1400 m; pod Olševo (Grom LJU 1970); Strevčev vrh pri Olševi, nad Rogarjem, 1400 m; Ludranski vrh (Grom LJU 1960); Javorniško sedlo (za Storžičem), 1400 m; Jelendol, 1350 m (Marinček \& Čarni 2007).

Rhytidiadelphus squarrosus (Hedw.) Warnst. bor-temp: Medji dol, 1000 m; Debelo brdo pod Belščico, 1200 m; dolina Koprivna, ob reki Koprivni, $900 \mathrm{~m}$; Olševa: Zadnji travnik, $1400 \mathrm{~m}$; dolina Topla, nad Fajmutom, $1400 \mathrm{~m}$.

Rhytidiadelphus triquetrus (Hedw.) Warnst. - bor-temp: Bašca (Piskernik 1977, det. Martinčič); Srednji vrh nad Gozd Martuljkom, $1000 \mathrm{~m}$; med Gozd Martuljkom in Belco, 700 m; Dovška Baba, 1800 m; Velika Golica, 1400 m; Hruški vrh, 1700 m; Klek, 1600 m; Krvavka, 1000 m; Korenščica, 1500 m; Potoška planina pod Belščico, $1300 \mathrm{~m}$; pri Valvazor- jevem domu pod Stolom, $1200 \mathrm{~m}$; Belščica (Paulin 1914); Gozdašnica nad dolino Završnico, 800 m; Begunjščica, 1000 m; Begunjščica (Piskernik 1971); Vranček pod Ljubeljem, $850 \mathrm{~m}$; Jelendol, pod Penatco, $900 \mathrm{~m}$; Medvodje pod Penatco, $850 \mathrm{~m}$; Spodnje Jezersko: Tisovec, 850 m; Zgornje Jezersko: pod Roblekom, $1000 \mathrm{~m}$; pod Pavličevim sedlom, pri kmetiji Covnik, $1200 \mathrm{~m}$; pod Pavličevim sedlom (Grom LJU 1970); Olševa: Zadnji travnik, 1400 m (Piskernik \& Martinčič 1970); Olševa, sev. pobočje, $1300 \mathrm{~m}$; Olševa, $1400 \mathrm{~m}$ (Kutnar et al. 2006, det. Martinčič); dolina Koprivna, 1000 m (Piskernik 1977, det. Martinčič); dolina Koprivna, ob reki Koprivni, 900 m; Peca, 1300 m (Piskernik 1977, det. Martinčič); Najbrževo pod Malo Peco, 1400 m (Kutnar et al. 2006, det. Martinčič); Strevčev vrh pri Olševi, nad Rogarjem, 1400 m; pod Olševo (Grom LJU 1970); Olševa: pri Potočki zijalki, $1700 \mathrm{~m}$ (Grom LJU 1970); Olševa, juž. pobočje, 800 m; Ludranski vrh (Grom LJU 1960); Uršlja gora: Kozakinovo; pod Uršljo goro, 1190 m (Marinček \& Čarni 2007); Uršlja gora, 1600 m; Uršlja gora, 1300 m (Piskernik 1977, det. Martinčič); Draga pri Begunjah, 690 m; Podljubelj (Grom LJU 1963); Dobrča (Piskernik 1977, det. Martinčič); Čadovlje pri Tržiču, 600 m; Jelendol, 1350 m (Marinček \& Čarni 2007).

Rhytidium rugosum (Hedw.) Kindb. - bor-temp: med Gozd Martuljkom in Belco, $700 \mathrm{~m}$; Begunjščica, 1000 m (LJU, L-2009); Podljubelj; Sv. Duh pod Olševo, pri Potočniku, 1200 m; nad Solčavo, levi breg reke Savinje (Grom LJU 1970); pri Solčavi ob Savinji (Dolšak LJU 1919); Uršlja gora (Wallnöfer 1888); dolina Tržiške Bistrice (Glowacki 1912).

Sanionia uncinata (Hedw.) Loeske - bor-mont: Dovška Baba, 1800 m; Velika Golica, 1800 m; Klek, 1600 m; Hruška planina pod Rožco, 1200 m; Krvavka, 1500 m; planina Pusti Rovt pod Korenščico, 1500 m; Struška Kočna, 1600 m; Vajnež, 2100 m; Begunjščica, 1900 m; Stol, 2000 m; nad planino Vrtačo, $1400 \mathrm{~m}$; pod Pavličevim sedlom, pri kmetiji Covnik, 1150 m; Olševa: barje Zadnji travnik, 1340 m (Piskernik \& Martinčič 1970); dolina Koprivna, $950 \mathrm{~m}$; dolina Topla, pod Burjakovim hribom, 700 m; Peca (leg. Planina); Črna na Koroškem (Wallnöfer 1888); Uršlja gora (Wallnöfer 1888); Uršlja gora, $1500 \mathrm{~m}$; Bačovski vrh, $1000 \mathrm{~m}$; Čadovlje pri Tržiču, 600 m; Javorniško sedlo (za Storžičem), $1400 \mathrm{~m}$. 
Schistidium apocarpum (Hedw.) Bruch \& Schimp. - bor-temp: nad Retečami, 1000 m; Peč, na tromeji, $1200 \mathrm{~m}$; Medvedjek nad Podkorenom, 1000 m; nad Gozd Martuljkom, 800 m; Srednji vrh nad Gozd Martuljkom, 1000 m; nad Dovjem, 800 m; Sv. Križ pri Planini pod Golico, 1000 m; Velika Golica, 1800 m; Krvavka, 1750 m; Hruški vrh, 1700 m; Medji dol, 1000 m; planina Pusti rovt pod Korenščico, 1500 m; Debelo Brdo pod Belščico, $1200 \mathrm{~m}$; dolina Završnica, $800 \mathrm{~m}$; Begunjščica, $1000 \mathrm{~m}$; pod Javornikom (za Storžičem), $800 \mathrm{~m}$; pod Ljubeljem, $950 \mathrm{~m}$; Spodnje Jezersko - Tisovec, $850 \mathrm{~m}$; dolina Koprivna, 900 m; dolina Topla, $800 \mathrm{~m}$; Strevčev vrh pri Olševi, nad Rogarjem, 1400 m; Sv. Duh pod Olševo, pri Potočniku, 1200 m; Uršlja gora: pobočje nad Ravnami (Glowacki 1908); Uršlja gora, 1650 m; Dolžanova soteska pri vasi Dolina, 750 m; dolina Tržiške Bistrice (Glowacki 1912).

*Schistidium confertum (Funck) Bruch \& Schimp. - bor-temp: Peč, na tromeji, $1200 \mathrm{~m}$; nad Podkorenom, $950 \mathrm{~m}$; Debelo Brdo pod Belščico, 1200 m; Olševa - Zadnji travnik, 1400 m.

*Schistidium crassipilum H.H. Blom - subtemp: nad Podkorenom, 950 m; Dovška Baba, 1850 m; Sv. Križ pri Planini pod Golico, 1000 m; Struška Kočna, 1800 m; med Javornikom pri Jesenicah in Javorniškim Rovtom, 800 m; Debelo Brdo pod Belščico, 1200 m; dolina Završnica, pod Begunjščico, $1000 \mathrm{~m}$; dolina Završnica, Žingarica, 800 m; Vranček pod Ljubeljem, 850 m; Spodnje Jezersko - Tisovec, $850 \mathrm{~m}$; Jelendol, pod Penatco, $900 \mathrm{~m}$; pod Pavličevim sedlom, pri kmetiji Covnik, $1200 \mathrm{~m}$; Mala Peca, 1400 m; dolina Topla, 800 m; dolina Topla, nad Fajmutom, 1100 m; Strevčev vrh pri Olševi, $1500 \mathrm{~m}$; Sv. Duh pod Olševo, pri Potočniku, 1200 m; Uršlja gora, 1650 m; Uršlja gora, vzhodno pobočje, 1100 m; Draga pri Begunjah na Gorenjskem, 690 m; Stolec nad Tržičem, 560 m; Čadovlje pri Tržiču, 600 m; Dolžanova soteska, $600 \mathrm{~m}$.

*Schistidium dupretii (Ther.) W.A. Weber - bor-mont: Velika Golica, 1500 m; Korenščica, 1600 m; Vajnež, 2100 m; Draga pri Begunjah na Gorenjskem, $700 \mathrm{~m}$.

*Schistidium elegantulum H.H. Blom subsp. elegantulum - temp: nad Dovjem, 800 m; Krvavka, 1700 m; Korenščica, 1600 m; pri Valvazorjevem domu pod Potoškim Stolom, 1200 m; Vajnež, $2100 \mathrm{~m}$; Begunjščica, $1000 \mathrm{~m}$; Stol, 1700 m; Spodnje Jezersko - Tisovec, 850 m;
Olševa - Zadnji travnik, 1400 m; dolina Topla, nad Fajmutom, 1400 m; Olševa, južno pobočje, $800 \mathrm{~m}$; Sv. Duh pod Olševo, pri Potočniku, $1200 \mathrm{~m}$; Čadovlje pri Tržiču, $600 \mathrm{~m}$.

*Schistidium lancifolium (Kindb.) H.H. Blom: Dolžanova soteska pri vasi Dolina, $750 \mathrm{~m}$. Primerki predstavljajo nekakšno prehodno obliko med $S$. apocarpum in $S$. lancifolium, pri čemer so bliže vrsti $S$. lancifolium.

*Schistidium papillosum Culm. - bor-mont: Sv. Duh pod Olševo, 900 m (Dolšak LJU 1931 sub $S$. gracile, det. Martinčič).

*Schistidium robustum (Nees \& Hornsch.) H.H. Blom - bor-mont: Struška Kočna, 1800 m; pri Valvazorjevem domu pod Potoškim Stolom, 1200 m; Stol, 1600 m, 1900 m; Jelendol, pod Penatco, $900 \mathrm{~m}$; Olševa, sev. pobočje, $1300 \mathrm{~m}$; Vajnež, $2100 \mathrm{~m}$;

*Schistidium trichodon (Brid.) Poelt var. trichodon - bor-mont: Kofce; pod Javornikom (za Storžičem), $800 \mathrm{~m}$.

*Sciuro-hypnum curtum (Lindb.) Ignatov \& Huttunen - temp: Olševa: Zadnji travnik, $1400 \mathrm{~m}$.

*Sciuro-hypnum flotowianum (Sendt.) Ignatov \& Huttunen - temp-subkont: pri Črni na Koroškem, proti Javorju, 650 m; Plešivški mlin pod Uršljo goro, $900 \mathrm{~m}$; Čadovlje pri Tržiču, $600 \mathrm{~m}$.

*Sciuro-hypnum glaciale (Schimp.) Ignatov \& Huttunen - subarkt-subalp: Begunjščica, 2000 m.

*Sciuro-hypnum plumosum (Hedw.) Ignatov \& Huttunen - bor-temp: Peč, pri planinskem domu Tromeja, $1200 \mathrm{~m}$; Medvedjek nad Podkorenom, 1000 m; Rateče, 900 m; nad Dovjem, $800 \mathrm{~m}$; Črni vrh nad Jesenicami, $1400 \mathrm{~m}$; Javorniški Rovt, 1100 m; dolina Završnica, 800 m; Ljubelj, 1000 m; dolina Koprivna, 1300 m; dolina Topla, $750 \mathrm{~m}$; Sv. Duh pod Olševo, pri Potočniku, $1200 \mathrm{~m}$; dolina reke Bistre, $650 \mathrm{~m}$; Zgornji Razbor, 700 m.

*Sciuro-hypnum populeum (Hedw.) Ignatov \& Huttunen - temp: Begunjščica, nad Poljško planino, $1500 \mathrm{~m}$; dolina Topla, pod Peco, $1130 \mathrm{~m}$ (Grom LJU 1959); dolina reke Bistre, 650 m; Zgornji Razbor, 700 m; Čadovlje pri Tržiču, $600 \mathrm{~m}$.

*Sciuro-hypnum reflexum (Starke) Ignatov \& Huttunen - bor-mont: Medji dol, 1000 m; Struška Kočna, 1600 m; Zgornje Jezersko: pod Roblekom, $1000 \mathrm{~m}$; dolina reke Bistre, $650 \mathrm{~m}$;

Sciuro-hypnum starkei (Brid.) Ignatov \& Huttunen - bor-mont: Petelinjek nad Korenskim sedlom, $1425 \mathrm{~m}$ (leg. Zupančič); Uršlja gora: pobočje nad Ravnami (Glowacki 1908); Hru- 
ška planina pod Rožco, 1200 m; Struška Kočna, 1600 m; Medji dol, 1000 m; Lajb pod Ljubeljem, 750 m; Spodnje Jezersko: Tisovec, ob Kokri, $850 \mathrm{~m}$; dolina Koprivna (Grom LJU 1960); dolina Topla (Martinčič 2004); Strevčev vrh pri Olševi (nad Rogarjem), 1400 m; Uršlja gora, $1400 \mathrm{~m}, 1650 \mathrm{~m}$.

Scorpidium cossonii (Schimp.) Hedenäs - bor-mont: Peč, 1250 m; Raduše: Smrčun (Zelnik et al. 2010); Kot pri Prevaljah (Zelnik et al. 2010); Sele, Blatnik (Zelnik et al., 2010); med Smokučem in Rodinami, $550 \mathrm{~m}$.

Seligeria recurvata (Hedw.) Bruch \& Schimp. bor-temp: Praprotnikov graben pri Begunjah na Gorenjskem (Glowacki 1912).

Sphagnum angustifolium (C. E. O. Jensen ex Russow) C. E. O. Jensen - subbor: barje pod Pavličevim sedlom, 1150 m (Martinčič 2004a); Olševa: barje Zadnji travnik, 1340 m (Martinčič 2004a).

Sphagnum auriculatum Schimp. - bor-temp: barje pod Pavličevim sedlom, blizu kmetije Covnik, 1150 m (Martinčič 2005).

Sphagnum capillifolium (Ehrh.) Hedw. - bor-temp: Črni vrh nad Jesenicami, $1290 \mathrm{~m}$ (leg. Zupančič); med Hruško planino in Sv. Križem pri Planini pod Golico, 1100 m; Jelendol, pod Penatco, $900 \mathrm{~m}$; barje pod Pavličevim sedlom, blizu kmetije Covnik, 1150 m (Kutnar \& Martinčič 2002); dolina Koprivna (Piskernik 1977, det. Martinčič); Olševa: barje Zadnji travnik, 1340 m (Piskernik \& Martinčič 1970); dolina reke Bistre, 650 m; pri Črni na Koroškem, proti Javorju, $650 \mathrm{~m}$.

Sphagnum centrale C. E. O. Jens. - bor-temp: Olševa: barje Zadnji travnik, 1340 m (Piskernik \& Martinčič 1970).

Sphagnum contortum K.F. Schultz - bor-mont: barje pod Pavličevim sedlom, blizu kmetije Covnik, 1150 m (Martinčič 2005); Olševa: barje Zadnji travnik, $1340 \mathrm{~m}$.

Sphagnum cuspidatum Ehrh. ex Hoffm. - bor-temp: barje pod Pavličevim sedlom blizu kmetije Covnik, 1150 m; Olševa: barje Zadnji travnik, 1340 m (Piskernik \& Martinčič 1970).

Sphagnum fallax (H. Klinggr.) H. Klinggr. bor-temp: barje pod Pavličevim sedlom, $1150 \mathrm{~m}$ (Martinčič 2004a); Olševa: barje Zadnji travnik, 1340 m (Piskernik \& Martinčič 1970, Martinčič 2004a).

Sphagnum flexuosum Dozy \& Molk. - bor-temp: Jelendol, $900 \mathrm{~m}$; barje pod Pavličevim sedlom, blizu kmetije Covnik, 1150 m (Kutnar \& Mar- tinčič 2002, Martinčič 2004a); Olševa: barje Zadnji travnik, 1340 m (Martinčič 2004a).

VU-Sphagnum fuscum (Schimp.) H. Klinggr. bor-mont: Olševa: barje Zadnji travnik, $1340 \mathrm{~m}$ (Piskernik \& Martinčič 1970).

Sphagnum girgensohnii Russow - bor-mont: med Hruško planino in Sv. Križem pri Planini pod Golico, 1100 m; Javorniški Rovt, 1100 m; Jelendol, pod Penatco, $900 \mathrm{~m}$; pod Pavličevim sedlom, pri kmetiji Covnik, 1200 m; Olševa, 1400 m; Strevčev vrh pri Olševi, nad Rogarjem, $1400 \mathrm{~m}$.

EN-Sphagnum inundatum Russow - bor-mont: barje pod Pavličevim sedlom, blizu kmetije Covnik, 1150 m (Martinčič 2005).

Sphagnum magellanicum Brid. - bor-mont: Jelendol, pod Penatco, $900 \mathrm{~m}$; barje pod Pavličevim sedlom, blizu kmetije Covnik, 1150 m (Kutnar \& Martinčič 2002); Olševa: barje Zadnji travnik, 1340 m (Piskernik \& Martinčič 1970).

Sphagnum palustre L. - bor-temp: Hruška planina pod Rožco, 1200 m; Jelendol, pod Penatco, $900 \mathrm{~m}$; barje pod Pavličevim sedlom, blizu kmetije Covnik, 1150 m; Olševa: barje Zadnji travnik, 1340 m (Piskernik \& Martinčič 1970).

*VU-Sphagnum platyphyllum (Lindb. ex Braithw.) Warnst. - bor-mont: Olševa: barje Zadnji travnik, $1340 \mathrm{~m}$.

NT-Sphagnum rubellum Wilson - bor-temp: Olševa: barje Zadnji travnik, 1340 m (Martinčič 2004).

Sphagnum russowii Warnst. - bor-mont: barje pod Pavličevim sedlom blizu kmetije Covnik, 1150 m (Kutnar \& Martinčič 2002); Olševa: Zadnji travnik, 1340 m (Piskernik \& Martinčič 1970).

Sphagnum squarrosum Crome - temp: Jelendol, pod Penatco, $900 \mathrm{~m}$; pod Pavličevim sedlom, pri kmetiji Covnik, $1200 \mathrm{~m}$.

Sphagnum subnitens Russ. ex Warnst. - bor-temp: med Hruško planino in Sv. Križem pri Planini pod Golico, 1100 m; Črni vrh nad Jesenicami, 1290 m (leg. Zupančič); Javorniški Rovt, 1100 m (Martinčič 2004); Jelendol, pod Penatco, 900 m; Zgornje Jezersko: pod Roblekom, $1000 \mathrm{~m}$; pod Pavličevim sedlom, pri kmetiji Covnik, 1200 m; Olševa: barje Zadnji travnik, $1340 \mathrm{~m}$; dolina Topla, pod Florinom, $850 \mathrm{~m}$; Olševa; pri Črni na Koroškem, proti Javorju, $650 \mathrm{~m}$.

*NT-Sphagnum subsecundum Nees - bor-mont: Olševa: barje Zadnji travnik, $1340 \mathrm{~m}$.

EN-Sphagnum teres (Schimp.) Ångstr. - bor- 
-mont: med Hruško planino in Sv. Križem pri Planini pod Golico, 1100 m (Martinčič 2004).

EN-Splachnum sphaericum Hedw. - bor-mont: Zelenica (Deschmann 1862, Müllner 1893).

Straminergon stramineum (Dicks. ex Brid.) Hedenäs - bor-mont: barje pod Pavličevim sedlom, blizu kmetije Covnik, 1150 m (Martinčič 2005, Kutnar \& Martinčič 2002).

*Syntrichia montana Nees - merid-temp: Uršlja gora, $1650 \mathrm{~m}$.

*Syntrichia ruralis (Hedw.) F. Weber \& D. Mohr - bor-temp: Dovška Baba, 1800 m; Klek, 1700 m; Velika Golica, 1400 m; Krvavka, 1750 m; Begunjščica, 1000 m; Ljubelj: Sv. Ana, 900 m; dolina Koprivna, 1200 m; Uršlja gora, 1600 m; Stolec nad Tržičem, 560 m; Dolžanova soteska, $600 \mathrm{~m}$.

Syntrichia norvegica F. Weber - subarkt-subalp: Dovška Baba, 1800 m; Velika Golica, 1400 m; Medji dol, 1000 m; Struška Kočna, 1600 m; Vajnež, 2100 m; Begunjščica, vrh (Merčun LJU 1929); Begunjščica, 2000 m; Stol, 2000 m (Dolšak LJU 1920); Stol, 2000 m.

Taxiphyllum wisgrillii (Garov.) Wijk \& Margad. temp: Bavha nad Podkorenom (Piskernik 1977, det. Martinčič); dolina Završnica, $800 \mathrm{~m}$; dolina Koprivna (Wraber M. 1963); dolina Tržiške Bistrice (Glowacki 1912.

Tayloria froelichiana (Hedw.) Mitt. ex Broth. subarkt-subalp: Stol, 2000 m (Martinčič 2004); Begunjščica, 2000 m; Olševa (Breidler 1891).

Tayloria serrata (Hedw.) Bruch \& Schimp. - subarkt-subalp: Begunjščica, $2000 \mathrm{~m}$ (Martinčič 2004); Zelenica (Deschmann 1862, Müllner 1893); Olševa: Zadnji travnik, $1400 \mathrm{~m}$.

Tetraphis pellucida Hedw. - bor-temp: Črni vrh nad Jesenicami, 1400 m (Martinčič 2004); Javorniški Rovt, 1100 m; Potoška planina pod Belščico, 1300 m; pri Javorniku blizu Jesenic (Paulin 1914); Gozdašnica nad dolino Završnico, 800 m; Zelenica (Müllner 1893); Begunjščica, 1000 m; dolina Završnica, pod Begunjščico, 1000 m; Jelendol, pod Penatco, 900 m; Spodnje Jezersko: Tisovec, $850 \mathrm{~m}$; Sleme nad dolino Koprivno (Grom LJU 1964); dolina Koprivna, $950 \mathrm{~m}$; dolina Topla, $750 \mathrm{~m}$; dolina Topla, pri Florinu, $900 \mathrm{~m}$; dolina Topla, nad Fajmutom, 1400 m; pri Črni na Koroškem, proti Javorju, 650 m; Uršlja gora: Kozarnica, 1000 m (Piskernik 1977, det. Martinčič); Uršlja gora, 1000 m (Piskernik 1977, det. Martinčič); Bačovski vrh, 1000 m; Zgornji Razbor, 700 m.

Thuidium assimile (Mitt.) A. Jaeger - temp: nad
Ratečami, 1000 m; nad Dovjem, 800 m; Hruška planina pod Rožco, 1200 m; pri Valvazorjevem domu pod Stolom, 1200 m; Javorniški Rovt, 1100 m; Gozdašnica nad dolino Završnico, 800 m; Begunjščica, $1000 \mathrm{~m}$; dolina Završnica: Žingarica, $800 \mathrm{~m}$; Ljubelj: Sv. Ana, 900 m (Martinčič 2004); Jelendol, pod Penatco, $900 \mathrm{~m}$; Spodnje Jezersko: Tisovec, $850 \mathrm{~m}$; Zgornje Jezersko: pod Roblekom, 1000 m; dolina Topla, nad Fajmutom, 1400 m; Strevčev vrh pri Olševi, nad Rogarjem, 1400 m; dolina reke Bistre, $650 \mathrm{~m}$; Spodnji Razbor pri Mislinjski Dobravi, $500 \mathrm{~m}$; Draga pri Begunjah na Gorenjskem, $690 \mathrm{~m}$; Čadovlje pri Tržiču, $600 \mathrm{~m}$; Dolžanova soteska, pri vasi Dolina, $750 \mathrm{~m}$.

var. pseudotamarisci (Limpr.) Mönkm.: Hruški vrh, 1700 m; Begunjščica, 2000 m (Martinčič 2004).

Thuidium delicatulum (Hedw.) Schimp. - temp: Rateče, 900 m; nad Gozd Martuljkom, 800 m; pri Črni na Koroškem (Wallnöfer 1888); Jazbina pri Žerjavu (Piskernik 1977, det. Martinčič); dolina reke Bistre pri Črni na Koroškem (Wallnöfer 1888); Čadovlje pri Tržiču, $600 \mathrm{~m}$.

Thuidium recognitum (Hedw.) Lindb. - temp: Ravnjakov vrh nad Prevaljami, 860 m (Grom LJU 1958); Javorniški Rovt, 1100 m (Martinčič 2004); Čadovlje pri Tržiču, $600 \mathrm{~m}$.

Thuidium tamariscinum (Hedw.) Schimp. - subbor: Javorniški Rovt, 1100 m; pri Valvazorjevem domu pod Stolom, 1200 m; Gozdašnica nad dolino Završnico, 800 m; dolina Završnica pri Žirovnici (Müllner 1893); Jezersko: med Roblekom in Vršnikom, 970 m (Marinček \& Čarni 2007); Zgornje Jezersko: pod Roblekom, $1000 \mathrm{~m}$; pod Pavličevim sedlom, pri kmetiji Covnik, 1200 m; Olševa: barje Zadnji travnik, 1340 m; dolina Koprivna, 1200 m; dolina Topla, pod Peco (Piskernik 1977, det. Martinčič); dolina Topla, nad Florinom, 850 m; Strevčev vrh pri Olševi, nad Rogarjem, 1400 m; Draga pri Begunjah na Gorenjskem, 690 m (Piskernik 1977, det. Martinčič); Dobrča (Piskernik 1977, det. Martinčič); Podljubelj, 860 m (Grom LJU 1963).

Timmia austriaca Hedw. - subarkt-subalp: Vajnež, 2100 m (Martinčič 2004); Stol, 2000 m; Olševa (Breidler 1891); Olševa: Potočka zijalka, vhod, $1700 \mathrm{~m}$.

*Timmia bavarica Hessl. - subarkt-subalp: Struška Kočna, 1600 m.

Timmia norvegica J.E. Zetterst. - subarkt-subalp: Struška Kočna, 1600 m (Martinčič 2004); 
Begunjščica, 2000 m; Stol, 2000 m (Martinčič 2004); Olševa (Breidler 1891); Olševa: Potočka zijalka, vhod, $1700 \mathrm{~m}$.

*NT-Tomenthypnum nitens (Hedw.) Loeske - bor-mont: Plešivški mlin pod Uršljo goro, $900 \mathrm{~m}$.

*Tortella densa (Lor. \& Mol.) Crundw. \& Nyholm - temp: nad Podkorenom, 1000 m; dolina Završnica, $800 \mathrm{~m}$; Olševa, juž. pobočje, $800 \mathrm{~m}$.

*Tortella fragilis (Hook. \& Wilson) Limpr. - subarkt-subalp: Begunjščica, 2000 m; Stol, 2000 m.

Tortella inclinata (R. Hedw.) Limpr. - temp: nad Ratečami, 1000 m; nad Gozd Martuljkom, 800 m; planina Pusti Rovt pod Korenščico, 1500 m; Uršlja gora: Kozarinovo (Martinčič 1976).

Tortella tortuosa (Hedw.) Limpr. - bor-temp: Peč, 1200 m; nad Ratečami, 1000 m; Medvedjek nad Podkorenom, 800 m; Za Robmi pri Kranjski Gori (Piskernik 1977, det. Martinčič); nad Gozd Martuljkom, 1000 m; Ravnjakov vrh nad Prevaljami, 860 m (Grom LJU 1958); Vrhe pri Slovenj Gradcu, 530 m; Belca; Dovška Baba, 1800 m; Krvavka, 1750 m; Sv. Križ pri Planini pod Golico, 1000 m; Hruška planina pod Rožco, 1250 m; Velika Golica, 1800 m; Klek, 1600 m; Medji dol, 1000 m; Struška Kočna, 1600 m; Korenščica, 1500 m; Javorniški Rovt, 1100 m; planina Pusti Rovt pod Korenščico, 1500 m; Potoška planina pod Belščico, 1300 m; Gozdašnica nad dolino Završnico, 800 m; Vajnež, $2100 \mathrm{~m}$; med Javornikom (Jesenice) in Javorniškim Rovtom, 800 m; pri Valvazorjevem domu pod Stolom, 1200 m; Debelo Brdo pod Belščico, $1200 \mathrm{~m}$; Begunjščica (Piskernik 1971); Begunjščica, 1000 m; Begunjščica, vrh, 2000 m; dolina Završnica, 800 m; dolina Završnica, pod Begunjščico, 1000 m; Stol, 1500 m, 2000 m (Dolšak LJU 1920); nad planino Vrtačo, 1400 m; Košuta: planina Kofce (Piskernik 1977); Podljubelj, 700 m; Vranček pod Ljubeljem, 850 m; Ljubelj, 1000 m; Ljubelj: Sv. Ana, 900 m; Jelendol nad Tržičem (Grom LJU 1959); Jelendol, pod Penatco, 900 m; Spodnje Jezersko: Tisovec, $850 \mathrm{~m}$; dolina Završnica: Žingarica, $800 \mathrm{~m}$; pod Pavličevim sedlom, pri kmetiji Covnik, 1200 m; Olševa, 1400 m (Kutnar et al. 2006, det. Martinčič); Olševa, sev. pobočje, 1300 m; Olševa: Zadnji travnik, 1400 m; dolina Koprivna, 1300 m; Najbrževo pod Malo Peco, $1400 \mathrm{~m}$ (Kutnar et al. 2006, det. Martinčič); Javorje pod Malo Peco, 1320 m (Kutnar et al. 2006, det. Martinčič); pod Peco (Piskernik 1977, det. Martinčič); Podpeca (leg. Planina); Mala Peca, 1400 m; Peca (leg. Planina); doli- na Topla, nad Fajmutom, 1100 m; Strevčev vrh pri Olševi, nad Rogarjem, 1400 m; Olševa: pod Potočko zijalko, 1600 m; Sv. Duh pod Olševo, pri Potočniku, 1200 m; Črna na Koroškem, breg reke Bistre, $620 \mathrm{~m}$ (Juvan 2008); dolina reke Bistre, $650 \mathrm{~m}$; Plešivec (Piskernik 1977, det. Martinčič); Uršlja gora, 1600 m; Kozarnica, vzh. od uršlje gore, 1000 m (Piskernik 1977, det. Martinčič); Blatnica, vzh. od Uršlje gore, 820 m (Piskernik 1977, det. Martinčič); Uršlja gora: Črni vrh, 1010 m (Grom LJU 1958); Uršlja gora: Plešivec, juž. pobočje, 890 m (Grom LJU 1958); Spodnji Razbor pri Mislinjski Dobravi, $500 \mathrm{~m}$; Podgorje pri Slovenj Gradcu, $450 \mathrm{~m}$; Završe pri Mislinji (Piskernik 1977, det. Martinčič); Draga pri Begunjah na Gorenjskem, 690 m (Piskernik 1977, det. Martinčič); Begunje na Gorenjskem (Müllner 1893); Sv. Peter nad Begunjami na Gorenjskem, 700 m (Piskernik 1977, det. Martinčič); nad Tržičem, $550 \mathrm{~m}$ (Dolšak LJU 1920); Čadovlje pri Tržiču, 600 m; Javorniško sedlo (za Storžičem), 1400 m; pod Javorniškim sedlom (za Storžičem), 800 m; Dolžanova soteska, pri vasi Dolina, 750 m; Jelendol, 1350 m (Marinček \& Čarni 2007).

*var. brevifolia Breidl. ex Limpr.: Begunjščica, 2000 m; Draga pri Begunjah na Gorenjskem, $690 \mathrm{~m}$.

var. fragilifolia (Jur.) Limpr. - temp-subkont: Hruški vrh, 1700 m; Begunjščica, 1000 m; pod Olševo, 1150 m (Grom 1970, det. Martinčič); Uršlja gora, Plešivec, 890 m (Grom LJU 1958, det. Martinčič); Uršlja gora, juž. stran (Grom LJU 1958); Podljubelj, 860 m (Grom LJU 1963, det. Martinčič).

*Tortula hoppeana (Schultz) Ochyra - subarkt-subalp: Krvavka, 1750 m; Begunjščica, vrh, $2000 \mathrm{~m}$.

Tortula mucronifolia Schwaegr. - bor-mont: graben Javorskega potoka pri Črni na Koroškem (Wallnöfer 1888).

*Tortula muralis Hedw. - temp: nad Podkorenom, 950 m; nad Dovjem, 800 m; Vranček pod Ljubeljem, $850 \mathrm{~m}$; pod Pavličevim sedlom, pri kmetiji Covnik, 1200 m; Smokuč pri Begunjah na Gorenjskem, 540 m; Draga pri Begunjah na Gorenjskem, 690 m; Čadovlje pri Tržiču, $600 \mathrm{~m}$; Stolec nad Tržičem, $560 \mathrm{~m}$.

*DD-Tortula schimperi M. J. Cano, O. Werner \& J. Guerra - merid-temp: Strevčev vrh pri Olševi, nad Rogarjem, $1400 \mathrm{~m}$.

Tortula subulata Hedw. - subtemp: Krvavka, 1750 m; Sv. Križ pri Planini pod Golico, 
1000 m; Hruški vrh, 1700 m; Medji dol, 1000 m; med Javornikom (Jesenice) in Javorniškim Rovtom, 800 m; Vajnež, 2100 m; Stol, 2000 m; Begunjščica, 2000 m; Košuta: planina Kofce (Piskernik 1977, det. Martinčič); pod Pavličevim sedlom, pri kmetiji Covnik, 1200 m; Strevčev vrh pri Olševi, nad Rogarjem, 1400 m; Uršlja gora (Piskernik 1977, det. Martinčič); Stegovnik (Piskernik 1977, det. Martinčič).

*var. graefii Warnst.: nad Podkorenom, 950 m; Dovška Baba, 1800 m.

*Ulota bruchii Hornsch. ex Brid. - temp: Ljubelj: Sv. Ana (Merčun LJU 1929); Medvodje pod Penatco, $850 \mathrm{~m}$; pod Pavličevim sedlom, pri kmetiji Covnik, 1200 m; dolina Koprivna, 1300 m; C̆adovlje pri Tržiču, $600 \mathrm{~m}$.

Ulota crispa (Hedw.) Brid. - temp: nad Dovjem, 800 m; Velika Golica, 1400 m; pri Valvazorjevem domu pod Stolom, $1200 \mathrm{~m}$; dolina Završnica, 800 m; Begunjščica, zah. pobočje, 1300 m; Lajb pod Ljubeljem, $850 \mathrm{~m}$; Medvodje pod Penatco, 850 m; Jelendol, pod Penatco, 900 m (L-2009); Spodnje Jezersko: Tisovec, 850 m; Zgornje Jezersko: pod Roblekom, 1000 m; pod Pavličevim sedlom, pri kmetiji Covnik, 1200 m; dolina Koprivna, 1300 m; Strevčev vrh pri Olševi, nad Rogarjem, 1400 m; Draga pri Begunjah na Gorenjskem, $690 \mathrm{~m}$; Čadovlje pri Tržiču, $600 \mathrm{~m}$; Javorniško sedlo (za Storžičem), 1400 m; Beli potok pri Podljubelju (Glowacki 1912).

Ulota hutchinsiae (Sm.) Hammar - bor-mont: dolina Tržiške Bistrice pri vasi Dolina (Glowacki 1912).

VU-Warnstorfia exannulata (Schimp.) Loeske bor-temp: Jelendol, pod Penatco, $900 \mathrm{~m}$; barje pod Pavličevim sedlom, blizu kmetije Covnik, 1150 m (Martinčič 2005).

Slika 2: Razporeditev geoelementov v mahovni flori Karavank, v odstotkih. Številke nad stolpci - število vrst (H - jetrenjaki; $\mathrm{M}$ - listnati mahovi). A: arktično-alpinski, subarktično-subalpinski; B: borealno-montanski; C: subborealni; Č: borealno-temperatni; D: temperatni, subtemperatni, temperatno-subatlantski; E: temperatno-subkontinentalni; F: meridionalno-temperatni, submediteransko-temperatni, submediteranski; G: ubikvisti

Figure 2: Distribution of bryophytes of the Karavanke Mts. over chorological elements (in \%). Number above bars number of species ( $\mathrm{H}$ - liverworts; $\mathrm{M}$ - mosses). A: arcticalpine, subarctic-subalpine; B: boreal-montane; C: subboreal; Č: boreal-temperate; D: temperate, subtemperate, temperate-subatlantic; E: temperate-subcontinental; F: meridionaltemperate, submediterranean-temperate, submediterranean; G: ubiquists
*Weisia controversa Hedw. - merid-temp: Črni vrh nad Jesenicami, $1360 \mathrm{~m}$ (leg. Piskernik); Stol, 2000 m; Olševa: Zadnji travnik, 1400 m;

*var. crispata (Nees \& Hornsch.) Nyholm - merid-temp: nad Podkorenom, $950 \mathrm{~m}$.

Weisia wimmeriana (Sendtn.) Bruch \& Schimp. - bor-mont: Korenščica, 1500 m; Vajnež (Breidler 1881-1901); Begunjščica-Srednji vrh (Breidler 1881-1901).

\subsection{HoROlošKa ANAliza}

Razporeditev vrst v posamezne geoelemente je prikazana na sliki 2. Hladnoljubni del mahovne flore predstavljajo vrste, ki jih prištevamo k arktično-alpinskemu oz. subarktično-subalpinskemu geoelementu $(11,3 \%$ - 9,8\%) ter borealno-montanskemu geoelementu (34,0\% - 23,5\%). Preseneča dejstvo, da je flora jetrenjakov v odstotnih deležih razločno bolj hladnoljubna kot flora listnatih mahov. Skupen delež najbolj hladnoljubnih vrst znaša $35,9 \%$.

Ob upoštevanju še subborealnih vrst $(12,4 \%$ - 5,7\%) je razvidno, da obsega hladnoljubna mahovna flora kar 196 vrst (43,1\%). Tako visok delež seveda ne preseneča, saj so Karavanke gorski sklop, ki v večjem delu dosega alpinski pas, marsikje pa presega tudi nadmorsko višino $2000 \mathrm{~m}$; najpomembnejši habitati hladnoljubnih mahovnih vrst pa so predvsem v zgornjem montanskem, subalpinskem in alpinskem pasu.

Borealno-temperatni geoelement obsega 113 vrst $(24,9 \%)$. Sem štejemo vrste, ki uspevajo tako $\mathrm{v}$ borealnem kakor tudi $\mathrm{v}$ temperatnem zonobiomu. V Karavankah je odstotni delež jetrenjakov $(23,7 \%)$ in listnatih mahov $(25,3 \%)$ tega

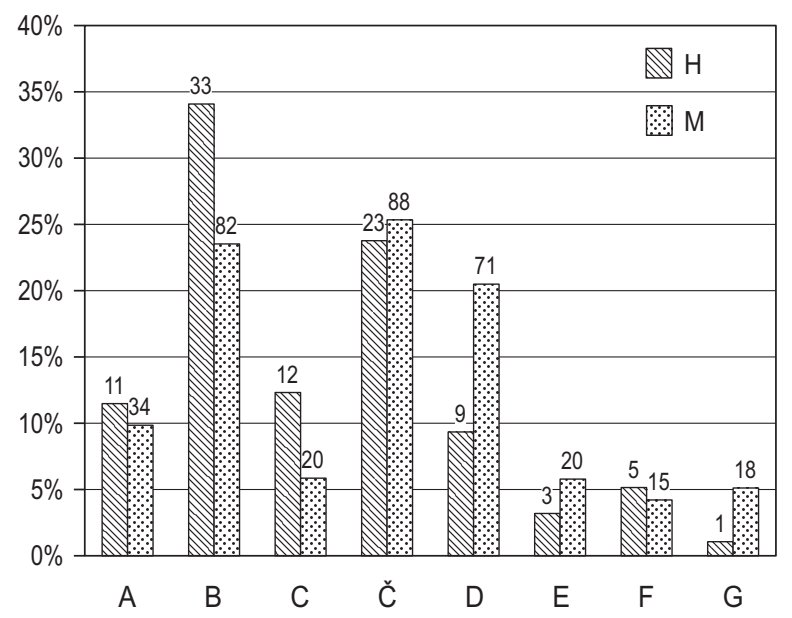


geoelementa približno enak. Najbolj pogosto uspevajo te vrste še $\mathrm{v}$ spodnjem montanskem pasu, vendar segajo nekatere celo $\mathrm{v}$ subalpinski in alpinski pas.

Temperatni geoelement (temperatni, temperatno-subkontinentalni $=$ srednjeevropski, subtemperatni, temperatno-subatlantski) obsega 104 vrste $(23,1 \%)$. Najštevilčnejšo podskupino predstavlja temperatni geoelement v ožjem pomenu, ki obsega splošno razširjene vrste temperatnega zonobioma $(64 \%$ - 14,3\%). Temperatno-subkontinentalni (= srednjeevropski) obsega 23 vrst $(5,1 \%)$ - to so vrste, ki v Evropi na zahodu ne dosegajo atlantskih predelov. Preostalih 16 vrst so subtemperatne $(10 \%-2,2 \%)$ in temperatno- subatlantske $(6 \%-1,3 \%)$. Podobno kot borealno-temperatne vrste tudi temperatne uspevajo predvsem v spodnjem montanskem pasu ter $\mathrm{v}$ spodnjem delu zgornjega montanskega pasu, redke pa segajo celo v subalpinski in alpinski pas Karavank.

Najbolj »toploljubno « skupino tvorijo meridionalno-temperatne vrste $(20 \%-4,5 \%$ : south-temperate sensu Hill \& Preston (1998); meridionalno-temperatne, submediteransko-temperatne, submediteransko-subatlantske). To so vrste, ki uspevajo $\mathrm{v}$ temperatnem in meridionalnem zonobiomu, vendar njihov areal sega proti jugu večinoma le še v submediteran. Njihova maloštevilnost $\mathrm{v}$ Karavankah je razumljiva. V skupini »druge« so ubikvisti $(20 \%-4,3 \%)$, vrste, ki so razširjene po vsej Evropi.

\subsection{OGROŽENOST MAHOVNE FLORE}

Ogroženost mahovne flore v fitogeografskem podobmočju Karavanke je danes razmeroma majhna. Razlogov za tako zadovoljivo stanje je več. Ker gre pretežno za gorski sklop, ima urbanizacija večji vpliv le v nižjih predelih, na vznožju, pa še tu je malo strnjenih naselij, npr. predel okrog Jesenic. Gospodarjenje z gozdnimi in traviščnimi površinami v glavnem ne ogroža sedanjih habitatov, zlasti še, ker ni večjih močvirnih površin, ki bi bile predmet hidromelioracij. Tudi stanje vodotokov in njihove neposredne okolice je večinoma naravno, saj se večji vpliv človeka prične šele v ravninskem svetu, ki pa je večidel že izven fitogeografskega podobmočja Karavanke. Turizem je zlasti v obliki planinskega pohodništva, omejen predvsem na okolico planinskih domov in je zanemarljiv. Teoretično največji vpliv predstavljajo prometnice, ki pa pomenijo v tem, veči- noma skalnatem svetu, z brežinami celo ugodno razširitev življenskega prostora za mahove.

$\mathrm{Za}$ opredelitev pripadnosti vrst posameznim kategorijam ogroženosti smo uporabili nove IUCN kriterije (IUCN 2001). Njihovo uporabo za mahove smo povzeli po Hallingbäck et al. (1998). Vendar je na sedanji stopnji poznavanja mahovne flore Slovenije edini realen kriterij razširjenost oz. število nahajališč pri nas (kriterij B), le pri nekaterih vrstah tudi potencialna ali dejanska ogroženost njihovih habitatov. Zato smo za razvrstitev vrst $\mathrm{v}$ posamezne kategorije uporabili številčno lestvico kot je za Madžarsko uporabljena v Papp et al. (2010), ali za Češko v Kučera et al. (2012). Na podlagi tako Revidiranega Rdečega seznama ogroženih mahov Slovenije (Martinčič 2013, mscr.) uspeva v fitogeografskem podobmočju Karavanke 21 ogroženih vrst in sicer $4 \mathrm{v}$ kategoriji prizadete $(\mathrm{EN})$ ter $17 \mathrm{v}$ kategoriji ranljive (VU). Nadalje, 11 vrst je v kategoriji NT, po štiri v kategorijah DD in DD-n. Na evropskem seznamu ogroženih mahovnih vrst (ECCB 1995) je 11 vrst, in sicer Myurella sibirica v kategoriji prizadete vrste (E), Buxbaumia viridis in Neckera pennata $\mathrm{v}$ kategoriji ranljivih vrst (V), ter 8 vrst v kategoriji redke (R): Fungermannia subulata, Lophozia ascendens, Amblystegium radicale, Anomodon rostratus, Brachythecium geheebii, Brachythecium oxycladum, Orthotrichum stellatum in Paraleucobryum sauteri.

\section{SUMMARY}

\section{Introduction}

Until recently, the moss flora of the Alpine phytogeographical region has been very unevenly studied. The only systematic research had been conducted by J. Glowacki who published his results as the moss flora of the Pohorje Mts. (1908), of the Julian Alps (1910) and of the Kamnik-Savinja Alps (1912). In these publications he included also the existing, but scattered papers by Slovenian and foreign botanists. After him there was no such research conducted in other subregions of the Alpine phytogeographical region. It was not until recently that moss flora was published for the subregion Dravski Kozjak (Martinčič 2010) and for the subregion Mežica-Mislinja Valley Strojna (Martinčič 2012). The only subregion left without a comprehensive presentation of its moss flora was therefore the Karavanke Mountains subregion (Figure 1). Until 1914, the data for 
moss flora of the Karavanke Mts. were contributed by Deschmann $(1862,1869)$, Wallnöfer (1888), Breidler (1891), Müllner (1893), Glowacki (1908, 1912) and Paulin (1914). Based on these data the moss flora comprised seven species of liverworts and 109 species of mosses. This was followed by a long period of bryofloristic inactivity. It was not until 1970 that new data on moss flora in the Karavanke Mts. were introduced, although only in published phytosociological relevés (Piskernik \& Martinčič 1970, Piskernik 1971, 1977, Kutnar, Urbančič \& Čas 2006, Marinček \& Čarni 2007, Juvan 2008, Juvan et al. 2011, Zelnik et al. 2010).

\section{Methods}

The author conducted systematic research of the moss flora of the Karavanke Mts. in two periods. First, in the period between 1960 and 1966, he collected moss material mainly in the higher regions of the western Karavanke Mts.; the material from the eastern Karavanke Mts. and from the lower regions was collected in the period 2000-2002. A part of his results was already considered in the list of mosses (Seznam listnatih mahov, Martinčič 2003) and in the list of liverworts (Seznam jetrenjakov, Martinčič 2011), and was published in several floristic papers.

Localities are equipped with the position in the Central-European floristic mapping system. The denotation in parenthesis is from UTM network (34T, the grid $10 \times 10 \mathrm{~km})$. Details are given in Slovenian text. In order to present the complete bryophyte flora of the subregion, the data from literature and unpublished data from herbarium LJU are included as well.

Nomenclature and taxonomy follows Schumacker \& Váňa (2005) for liverworts and Hill et al. (2006) for mosses. Floral elements are given according to Düll et al. (1999), partly modified after Hill \& Preston (1998) and Martinčič (1966, 2006). The specimens are preserved in the Herbarium of Department of Biology (Biotechnical faculty) University of Ljubljana.

\section{Floristical results}

The bryophyte flora of the phytogeographical subregion Karavanke comprises 453 species, 356 of which are mosses (Bryophyta) and 97 are liverworts (Marchantiophyta). For mosses, this number represents $56 \%$ of the currently recorded species in Slovenia (Martinčič 2003, Ros et al. 2013). The number of liverworts represents $58 \%$ currently known species in Slovenia (Martinčič 2011). As many as 3 species of liverworts and 91 species of mosses are new to the subregion Karavanke. Twelve species are reported for the first time from Slovenia: Cephalozia ambigua, Lophozia ascendens, Dicranella crispa, Didymodon asperifolius, Brachytheciastrum olympicum, Schistidium crassipilum, S. dupretii, S. elegantulum subsp. elegantulum, S. lancifolium, S. papillosum, S. robustum, S. trichodon var. trichodon. Floristically significant species with fewer than five localities in Slovenia are also: Anthelia juratzkana, Asterella gracilis, Athalamia hyalina, Blepharostoma trichophyllum subsp. brevirete, Cephalozia pleniceps, Diplophyllum taxifolium, Jungermannia polaris, Lophozia badensis, Lophozia elongata, Peltolepis quadrata, Tritomaria exectiformis subsp. exectiformis among liverworts and Cynodontium fallax, Encalypta affinis, Eurhynchium pulchellum var. diversifolium, Grimmia elatior, Kiaeria starkei, Racomitrium affine, Sciuro-hypnum glaciale, Tortula schimperi among mosses. A more than half of these species represent arctic-alpine/subarcticsubalpine floral element, the remaining part of species belong to the boreal-montane element.

Cephalozia ambigua: subarctic-alpine geoelement; in Europe, it is distributed in Scandinavia and in mountain ranges from the Pyrenees, across Alpine regions further east to Russia. In southeast Europe, the species has so far been recorded in Bulgaria and Romania (Sabovljević \& Natcheva 2006), and in Macedonia (Martinčič 2009). Both localities in the Karavanke Mts. are situated in the subalpine belt. In 2003, the species was found also in the Julian Alps, on Mt. Mangart - Rdeča skala, $2100 \mathrm{~m}$ a.s.l., in the alpine belt.

Lophozia ascendens: boreal-montane species growing mainly on decaying wood, in montane coniferous forests on sites with high air humidity. In Europe, it occurs in Scandinavia and in European mountains; in the Balkan Peninsula it is known only from Bulgaria and Serbia (Papp \& Erzberger 2005, Ros et al. 2007). The locality in Slovenia is therefore part of the wider CentralEuropean section of its distribution area. Based on this distribution area it can be assumed to be more widely distributed in Slovenia than evident from the current situation, as it is likely to be frequently overlooked due to its small size. It has already been mentioned for Slovenia (Martinčič 2011a), but without a precise locality. 
Brachytheciastrum olympicum: subatlanticsubmediterranean species distributed in the wider Mediterranean region. Pavletić \& Grom (1958) mention it for Sežana (Slovenia), in the subMediterranean phytogeographical region; Grom $(1963,1969)$ mentions it without a precise location for the Trno vski gozd plateau in the Dinaric phytogeographical region. Herbarium material from both localities is kept in LJU, but without sporogones. Considering that a smooth seta is a significant distinguishing character which clearly differentiates $B$. olympicum from $B$. velutinum, both descriptions are doubtful (Martinčič 2003).

Dicranella crispa: boreal-montane species that occurs on damper, especially sandy bedrock, on streamsides, frequently on secondary sites, on road banks. In Europe, it occurs in Scandinavia and across a wide belt from Spain to Russia, scattered to rare. The only known location in southeast Europe is in Romania. Localities in Slovenia are therefore on the southern edge of the contiguous European distribution area. The species was mentioned for Slovenia already by Reichardt (1860) for the vicinity of Dobrna, but this location is highly doubtful considering how long it has been since this information was published. Locality Olševa: Zadnji travnik, 1400 m; the first reliable information on the occurrence of this species in Slovenia is from 2001. In 2011, the species was found also in Strojna (Libeliška gora, Ridlov graben and the valley of the Šentanel river near Zgonik's mill); on both these localities it grows on the road bank. Despite precise classification both these data were incorrectly published in Martinčič 2012 for Dicranella schreberiana.

Didymodon asperifolius: Arctic-alpine geoelement, in Europe commonly occurring to the south of Scandinavia in the subalpine and alpine belts. Pavletić (1955) mentions the species for Slovenia based on J. Šafer's herbarium. This material, however, is not included in this herbarium, nor is it mentioned by Głowacki (1913), who published all Šafer's herbarium localities. The first reliable locality in Slovenia is the hamlet Lajb under Ljubelj, along the stream Mošenik, at the elevation $800 \mathrm{~m}$. This is also its southernmost locality in the Alpine part of the distribution area, as for the time being the species is not known in the Balkan Peninsula (Ros et al. 2013). Low elevation and the stream bank lead to the conclusion that the site of the studied species is secondary and that deposits from higher areas have accumulated here.

\section{Chorological analysis}

Distribution of species into geoelements is presented in Figure 2. The frigoriphilous part of the moss flora consists of species belonging to the arctic-alpine or subarctic-subalpine geoelement $(11.3 \%-9.8 \%)$ and boreal-montane geoelement $(34.0 \%-23.5 \%)$. It is surprising that in percentage the liverwort flora is distinctly more frigoriphilous than moss flora. The total proportion of the most frigoriphilous species is $35.9 \%$. With consideration of sub-boreal species $(12.4 \%-5.7 \%)$ it is evident that frigoriphilous moss flora comprises as many as 196 species (43.1\%). Such high proportion is not surprising, as the Karavanke Mountains area mountain range that for the most part reaches the alpine belt and frequently exceeds $2000 \mathrm{~m}$ in elevation; the most important habitats of frigoriphilous moss species are mainly in the upper montane, subalpine and alpine belts.

The boreal-temperate geoelement comprises 113 species (24.9\%). These include the species that occur in boreal as well as in temperate zonobiomes. In the Karavanke Mts., the percentage of liverworts (23.7\%) and mosses (25.3\%) of this geoelement is about the same. These species are the most frequent in the lower montane belt, with some of them extending to the subalpine and alpine belts.

The temperate geoelement (temperate, temperate-subcontinental $=$ Central European, subtemperate, temperate-subatlantic) comprises 104 species $(23.1 \%)$. The most numerous subgroup is the temperate geoelement in the narrow sense, comprising widespread species of the temperate zonobiome (64\% - 14.3\%). The temperatesubcontinental (= Central-European) geoelement comprises 23 species (5.1\%) - these are the species that in the west of Europe do not reach the Atlantic regions. The other 16 species are subtemperate $(10 \%-2.2 \%)$ and temperate subatlantic species $(6 \%-1.3 \%)$. Similarly to boreal-temperate species, temperate species also occur mainly in the lower montane belt and in the lower part of the upper montane belt, rarely extending to the subalpine and alpine belt of the Karavanke Mountains.

The most "thermophilous" group consists of meridional-temperate species (south-temperate sensu Hill \& Preston 1998). These species occur in the temperate and meridional zonobiomes, but their distribution area extends to the south mainly to the sub-Mediterranean. Their scarcity 
in the Karavanke Mts. is understandable. The group "other" comprises ubiquitists, the species distributed across Europe.

\section{Threatened taxa}

The new IUCN criteria (IUCN 2001) were applied in the classification of species into Red List categories. Their application to mosses follows Hallingbäck et al. (1998). However, at the current level of knowledge of Slovenian moss flora, the only realistic criterion is distribution or the number of sites in Slovenia (criterion B), for some species also potential or actual threat status of their habitats. To categorise individual species we therefore used a numerical scale as the one used for Hungary in Papp et al. (2010), or for the Czech Republic in Kučera et al. (2012).

When taking into consideration the Updated Red list of Slovenian Bryophytes (Martinčič mscr. 2013) 21 species are considered threatened. Four species are included in the category endangered (EN) and 17 are included in category vulnerable (VU). Further, 11 species are in the category near threatened (NT), four in data deficient (DD) and four in data-deficient new (DD-n). In the Red Data Book of European Bryophytes (ECCB 1995) 11 species are included: Myurella sibirica as endangered (EN), Buxbaumia viridis, Neckera pennata as vulnerable (VU) and 8 species as rare (R): Fungermannia subulata, Lophozia ascendens, Amblystegium radicale, Anomodon rostratus, Brachythecium geheebii, Brachythecium oxycladum, Orthotrichum stellatum and Paraleucobryum sauteri.

\section{LITERATURA}

Breidler, J. 1891: Die Laubmoose Steiermarks u. ihre Verbreitung. Mitt. Naturw. Ver. f. Steierm. Jahrgang 1891: 1-234.

Breidler, J. 1894: Die Lebermoose Steiermarks. Mitt. Naturwiss. Ver. f. Steierm. Jahrgang 1894: 256-357.

Breidler, J.: Moose aus Krain, den Julischen Alpen, Gebiet von Görz und Istrien, gesammelt in den Jahren 1881-1901. Mscr.

Dakskobler, I., Rozman, A. \& Vreš, B. 2012: Nova spoznanja o razširjenosti in rastiščih vrste $L i$ stera cordata (L.) R. Br. v Sloveniji. Hladnikia 29: 3-18.
Deschmann, K. 1858: Über die Auffindung verschiedener Leber- und Laubmoose in Krain. Zweites Jahresheft der Verein der krainischen Landesmuseums, p. 105.

Deschmann, K. 1862: Über die Auffindung verschiener Leber- und Laubmoose in Krain. Drittes Jahresheft der Verein der krainischen Landesmuseums. p. 196, 221, 228, 229.

Deschmann, K. 1869: Monatsversammlung der Verein der krainischen Landesmuseums. Laibacher Tagblatt Nr. 17 (22. Januar 1869).

Düll, R., Pavletić, Z. \& Martinčič, A. 1999: Checklist of the Yugoslavian bryophytes, in Düll, R., Ganeva, A., Martinčič, A. \& Pavletić, Z.: Contributions to the bryoflora of former Yugoslavia and Bulgaria. IDH-Verlag Bad Münstereifel. pp. 1-110.

ECCB, 1995: Red data book of European bryophytes. European Committee for Conservation of Bryophytes. Trondheim. 291 pp.

Glowacki, J. 1908: Ein Beitrag zur Kenntnis der Laubmoosflora von Kärnten. Jahrb. naturh. Mus. f. Kärnten, Klagenfurt 28: 165-186.

Glowacki, J. 1912: Moosflora der Steiner Alpen. Jahrb. naturh. Mus. f. Kärnten, Klagenfurt »Carinthia II N Nr.1-6:13-47; 130-156.

Glowacki, J. 1913: Ein Beitrag zur Kenntnis der Moosflora der Karstländer. Izvestja muz. društva za Kranjsko "Carniola" nov. ser. 4: 114-153.

Grom, S. 1963: Beiträge zur Moosflora Sloweniens (Jugoslawien) II. Nova Hedwigia 5: 477-486.

Grom, S. 1969: Mahovna flora Trnovskega gozda. Varstvo narave 6: 51-72.

Hallingbäck, T., Hodgetts, N., Raeymaekers, G., Schumacker, R., Sérgio, C., Söderström, L., Stewart, N. \& Váňa, J. 1998: Guidelines for application of the revised IUCN threat categories to bryophytes. Lindbergia 23: 6-12.

Hill, M. O. \& Preston, G. D. 1998: The geographical relationships of British and Irish bryophytes. Journal of Bryology 20: 127-226.

Hill, M. O., Bell, N., Bruggeman-Nanenga, M. A., Brugues, M., Cano, M. J., Enroth, J., Flatberg, K. I., Frahm, J.-P., Galego, M. T., Garilleti, M., Guerra, J., Hedenäs, L., Holyoak, D. T., Hyvönen, J., Ignatov, M. S., Lara, F., Mazimpaka, V., Munoz, J. \& Söderström, L. 2006: An annotated checklist of the mosses of Europe and Macaronesia. Journal of Bryology 28 (3): 198-267.

IUCN 2001: IUCN Red list categories and criteria. Version 3.1. IUCN Species Survival Commission, Gland, Switzerland \& Cambridge. 
Juvan, N. 2008: Vegetacija skalnih razpok silikatnega skalovja. Diplomska naloga, Univerza v Ljubljani, 139 pp.

Juvan, N., Čarni, A. \& Jogan, N. 2011: Chasmophytic vegetation of silicate rocks on the southern outcrops of the Alps in Slovenia. Wulfenia 18: 133-156.

Košir, P. 2002: Prispevek k sinsistematiki združbe Hacquetio-Fraxinetum excelsioris Marinček in Wallnöfer et al. 1993. Hacquetia 1(1): 109-131.

Kučera, J., Váňa, J. \& Hradílek, Z. 2012: Bryophyte flora of Czech Republic: updated checklist and Red list and a brief analysis. Preslia 84: 813-850.

Kutnar, L. \& Martinčič, A. 2002: Inicialna oblika barjanskega smrekovja Piceo-Sphagnetum flexuosi ass. nova v Sloveniji. Razprave IV. razreda SAZU 43(3): 247-266.

Kutnar, L, Urbančič, M. \& Čas, M. 2006: Ohranjenost gozdnih tal in vegetacije $\mathrm{v}$ habitatu divjega petelina $\mathrm{v}$ vzhodnih Karavankah in vzhodnih Kamniško-Savinjskih Alpah. Zbornik gozdarstva in lesarstva 77: 5-42.

Marinček, L. \& Čarni, A. 2007: Illyrian pre-alpine fir and beech forests - the association Homogyno sylvestris-Fagetum Marinček et al. 1993. Hacquetia 6(2): 111-129.

Marinček, L. \& Čarni, A. 2010: Altimontanski bukovi gozdovi podzveze Saxifrago-Fagenion (Aremonio-Fagion). Scopolia 69: 1-107.

Martinčič, A. 1966: Elementi mahovne flore Jugoslavije ter njihova horološka in ekološka problematika. Razprave SAZU, 4. razr. IX (1): 5-82.

Martinčič, A. 1976: Prispevek k floristiki mahov (Bryophyta) v Sloveniji I. Biološki vestnik 24 (1): 89-93.

Martinčič, A. 2003: Seznam listnatih mahov (Bryopsida) Slovenije. Hacquetia 2(1): 91-166.

Martinčič, A. 2003a: Kritični prispevki za mahovno floro Slovenije, 1-12. Hladnikia 15-16: 5-15.

Martinčič, A. 2004: Nova nahajališča vrst - Mahovi (Bryophyta). Hladnikia 17: 50-58.

Martinčič, A. 2004a: Kritični prispevki za mahovno floro Slovenije, 13-15. Hladnikia 17: 13-22.

Martinčič, A. 2005: Nova nahajališča - Bryophyta. Hladnikia 18: 49-56.

Martinčič, A. 2007: Kritični prispevki za mahovno floro Slovenije, 16-23. Hladnikia 20: 17-25.

Martinčič, A. 2009: Nova nahajališča vrst 24 Bryophyta. Hladnikia 24: 75-81.

Martinčič, A. 2009a: Contributions to the bryophyte flora of republic Macedonia. Hacquetia 8 (2): 97-114.
Martinčič, A. 2010: Nova nahajališča: Mahovi jetrenjaki (Marchantiophyta). Hladnikia 26: 67-76.

Martinčič, A. 2011: Nova nahajališča: Mahovi jetrenjaki (Marchantiophyta). Hladnikia 27: 77-88.

Martinčič, A. 2011a: Seznam jetrenjakov (Marchantiophyta) in rogovnjakov (Anthocerotophyta) Slovenije. Scopolia 72: 1-38.

Martinčič, A. 2012: Nova nahajališča: Mahovi listnati mahovi (Bryopsida), jetrenjaki (Marchantiopsida). Hladnikia 29: 69-71

Martinčič, A. 2013: Updated Red List of Slovenian Bryophytes. Mscr.

Müllner, A. 1893: Beiträge zur Moosflora Krains. Argo - Zeitschrift für krain. Landeskunde 2: 34-37.

Papp, B. \& Erzberger, P. 2005: The bryophyte flora of Golija-Studenica Biosphere Reserve and some adjacent sites (SW Serbia, SerbiaMontenegro). Studia Botanica Hungarica 36: 101-116.

Papp, B., Erzberger, P., Ódor, P., Hock, Zs., Szövenyi, P., Szurdoki, E. \& Toth, Z. 2010: Updated checklist and red list of Hungarian bryophytes. Studia Botanica Hungarica 41: 31-59.

Paulin, A. 1914: Podatki o razširjenosti mahov v Sloveniji. Rokopisni seznam.

Pavletić, Z. 1955: Pavletić Z., 1955: Prodromus flore briofita Jugoslavije. Jugoslovenska akademija znanosti i umjetnosti Posebna izdanja odjela za prirodne nauke. Knjiga III. Zagreb, pp. 578.

Pavletić, Z. \& Grom, S. 1958: Quelques Bryophy-tes nouveaux en Yugoslavie et en Slovenie. Revue Bryologique et Lichénologique 27 (3-4): 186-187.

Perko, D. \& Adamič-Orožen, M. (ur.) 1998: Nova regionalizacija Slovenije. V: Slovenija - pokrajine in ljudje. Mladinska knjiga pp. 26-33.

Piskernik, M. 1971: Regionalna vegetacijska razčlenitev bazifilnih bukovih gozdov v Sloveniji. Zbornik Biotehniške fakultete, Inštitut za gozdno in lesno gospodarstvo 10: 65-115.

Piskernik, M. 1977: Gozdna vegetacija Slovenije v okviru Evropskih gozdov. Zbornik gozdarstva in lesarstva 15: 1-236.

Piskernik, M. \& Martinčič, A. 1970: Vegetacija in ekologija gorskih barij v Sloveniji. Zbornik biotehniške fakultete 8: 131-203.

Reichardt H. W., 1860: Die Flora des Bades Neuhaus nächst Cilli. Verh Zool. Bot. Ges. Wien 10: 713-742. 
Ros, R.M., Mazimpaka, V., Abou-Salama, U., Aleffi, M., Blockeel, T.L., Brugués, M., Cano, M.J., Cros, R.M., Dia, M.G., Dirkse, G.M., El Saadawi, W., Erdağ, A., Ganeva, A., GonzálezMancebo, J.M., Hernstadt, I., Khalil, K., Kürschner, H., Lanfranco, E., Losada-Lima, A., Refai, M.S., Rodríguez-Nunez, S., Sabovljević, M., Sérgio, C., Shabbara, H., Sim-Sim, M., Söderström, M. 2007: Hepatics and Anthocerotes of the Mediterranean, an annotated checklist. Cryptogamie, Bryologie 28 (4): 351-437.

Ros, R.M., Mazimpaka, V., Abou-Salama, U., Aleffi, M., Blockeel, T.L., Brugués, M., Cros, R.M., Dia, M.G., Dirkse, G.M., Draper, I., El Saadawi, W., Erdağ, A., Ganeva, A., Gabriel, R., González-Mancebo, J.M., Hernstadt, I., Hugonnot, V., Khalil, K., Kürschner, H., Losada-Lima, A., Luís, L., Mifsud, S., Privitera, M., Puglisi, M., S., Sabovljević, M., Sérgio, C., Shabbara, H.M., Sim-Sim, M., Sotiaux, A., Tacchi, R., Vanderpoorten, A., Werner, O., 2013: Mosses of the Mediterranean, an annotated checklist. Cryptogamie, Bryologie 34 (2): 99-283.

Sabovljević, M. \& Natcheva, R. 2006: A check-list of the liverworts and hornworts of Southeast Europe. Phytologia Balcanica 12(2): 169-180.

Sabovljević, M., Natcheva, R., Dihoru, G., Tsakiri, E., Dragićević, S., Erdag, A. \& Papp, B.
2008: Check-list of the mosses of Southeast Europe. Phytologia Balcanica 14 (2): 159-196.

Schumacker, R. \& Váňa, J. 2005: Identification keys to the liverworts and hornworts of Europe and Macaronesia. 2. ed. Poznań 2005. 269 pp.

Sendtner, O. 1857: Moose aus Kärnten, Görz, Krain, Istrien, Quarnerischen Inseln und Dalmatien. Verh. Zool. Bot. Ges. Wien 7: 14-16 Sitzungsber.

Suanjak, M. 2002: Dupla Graecensis Bryophytorum (2002). Moose aus dem Nachlas von Julius Glowacki. Fritschiana 35: 17-49.

Wallnöfer, A. 1888: Die Laubmoose Kärntens. Jahrb. des naturhist. Landesmus. von Kärnten 20: $1-155$.

Wraber, M. 1963: Gozdna združba smreke in gozdne bekice v slovenskih vzhodnih Alpah. Razprave SAZU, razr. za prirod. in med. vede, 7: 79-175.

Zelnik, I., Martinčič, A. \& Vreš, B. 2010: Vegetation of the depressions with Eleocharis quinquefolia in spring fens in Slovenia. Acta Biologica Slovenica 53 (2): 23-31.

Received 5.12.2013

Revison received: 10.2.2014

Accepted 12.2.2014 